\title{
COMPORTAMENTO DE CULTIVARES DE PEPINO (Cucumis satious L.) EM DUAS ÉPOCAS DE SEMEADURA
}

\author{
MARIA ESMERALDA SOARES PAYÃO DEMATTÊ
}

Orientador: DR. SALIM SIMAOO

Dissertação apresentada à Escola Superior de Agricultura "Luiz de Queiroz", da Universidade de São Paulo, para obtenção do título de Mestro em Fitotecnia

PIRACICABA

Estado de Sāo Paulo - Brasil

Maio, 1978 
COMPORTAMENTO DE CULTIVARES DE PEPINO

(Cucumis sativus L.) EM DUAS EPOCAS DE SEMEADURA 
A meus pais e a João Batista, com gratidão e amor, ofereço. 


\section{AGRADECIMENTOS}

Diversas pessoas e instituições tornaram possível a realização deste trabalho. Agradeço especialmente:

- ao Prof. Dr. Salim Simão, pela orientação experiente e extremamente dedicada;

- ao Sr. Armando Bonato, pela competência e zelo com que executou os trabalhos de campo;

- ao Dr. Leocâdio de Souza Camargo, pelo apoio;

- aos têcnicos e funcionários das Seções de Horta liças de Frutos, Climatologia Agrícola, Pedologia e Fertí lidade do Solo do Instituto Agronômico do Estado de São Paulo, pela colaboração;

- ao Conselho Nacional de Pesquisas, pela concessão de auxîlio financeiro;

- à Fundação de Amparo â Pesquisa do Estado de São Paulo, pelo fornecimento de condução para transporte de materiais;

- ao Dr. Nelson Moreira de Carvalho, pelas sugestões e pelo estimulo;

- ao Departamento de Fitotecnia da Faculdade de Ciências Agrärias e Veterinärias do "Campus" de Jaboticabal e ao Departamento de Química da Escola Superior de Agricultura "Luiz de Queiroz", por terem oferecido condi çōes propícias à realização da fase final do trabalho;

- ao Dr. Edmar F. Cabral de Vasconcellos, pelo em préstimo de livros utilizados na revisão de literatura;

- ao Dr. Rodolfo Hoffmann, ao Eng. Agr. Franciśco Antonio Passos, ã Eng. Agr. Violeta Nagai, ao Dr. João Carlos de Oliveira, ao Dr. Alfredo Lam-Sánchez, ao Dr . Aristeu Mendes Peixoto e aos docentes do Departamento de 
Ciências Exatas da Faculdade de Ciências Agrärias e Veterinárias do "Campus" de Jaboticabal, pelas informações presta das;

à Dra. Samira Miguel Campos de Araujo, pelo incen tivo constante;

- ao Dr. Keigo Minami, pela relevante ajuda;

- a D. Yvonne Casale Padovani, pelo auxílio e pela atenção;

- ao Sr. Lazaro Martins, pelo empenho na realização de seus serviços gräficos;

- à bibliotecāria Sonia Corrêa da Rocha, pela revisão das referências bibliogräficas;

- à Srta. Maria Benedita Donadon, pelos serviços de datilografia;

- ao Sr. William Charles Ducret, pelos serviços fotogräficos;

- a Sidneide Manfredini, pela colaboração espontâ nea e desprendida;

- a minha familia, pelo apoio e pela motivação. 


\section{TNDICE}

Página

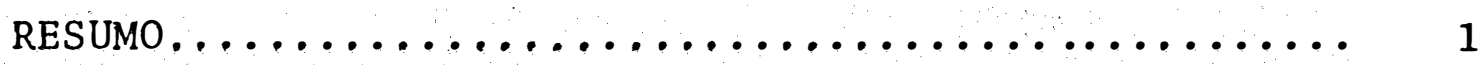

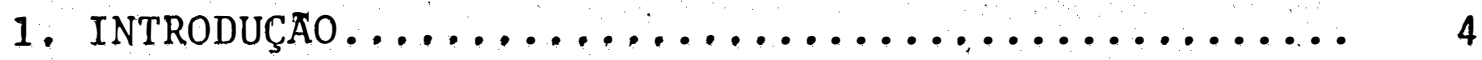

2. REVISAO DE LITERATURA........................ 5

2.1. Influência das condiçōes climäticas na cultu- 5

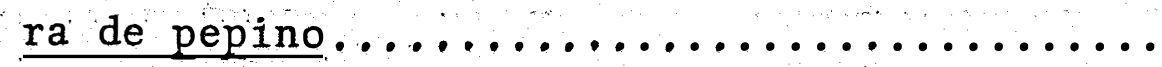

2.1 .1 . Informaçōes gerais........... 5

2.1.2. Influência da temperatura na germina ção das sementes................ 6

2.1.3. Influência da temperatura e da umidade no desenvolvimento das plantas....... 7

2.1.4. Influência de algumas características da luz no desenvolvimento das plantas 9

2.1.5. Influéncia de fatores climăticos na ex pressão do sexo................. 10

2.2. Influência da localizaçâo dos frutos na planta sobre a produção tota1............... 12

2.3. Correlação entre a produção e outras varia -

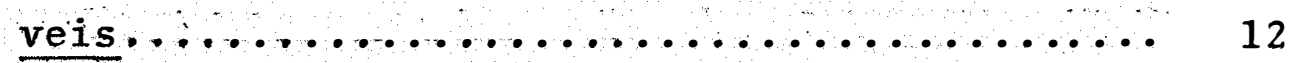

2.4. Comportamento das cultivares estudadas $\quad 14$

3. MATERIAL E METODOS ...................... 18

3.1. Caracterização do local do experimento...... 18

3.2. Caracterização das plantas estudadas........ 19

3.2.1. Classificação botânica........... 19

3.2.2. Informações sobre as cultivares estu dadas...................... 19

3.2 .2 .1 . Marketer............. 22

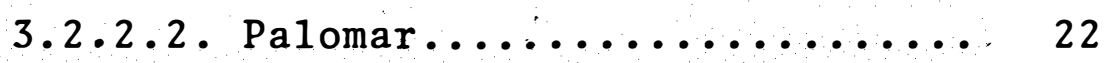

3.2.2.3. Santee............... 23

3.2 .2 .4 . Verde Paulistano.......... 23

3.2 .2 .5 . Aodai............... 23 
3.3. Dados culturais.................. 24

3.3.1. Epocas de semeadura.............. 24

3.3.2. Preparo do solo, preparo das covas e espaçamento................... 24

3.3.3. Semeadura.................. 25

3.3.4. Desbastes................... 26

3.3.5. Condução das plantas............ 26

3.3.6. Adubações em cobertura.......... 26

3.3.7. Tratamento fitossanitário........ 26

3.3 .8 . Irrigação................ 27

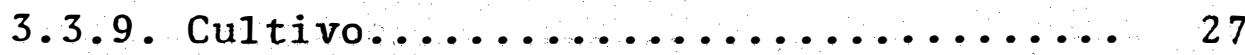

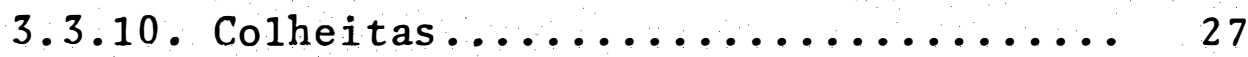

3.4. Delineamento estatístico............ 28

3.5. Características estudadas na cultura...... 28

3.6. Análise estatística dos dados.......... 30

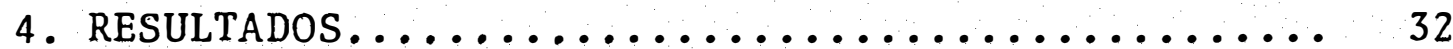

4.1 . Considerações gerais.............. 32

4.1.1. Primeira época de semeadura $(5 \%$ de maio de 1970 ................. 32

4.2.2. Segunda êpoca de semeadura ( 5 de de zembro de 1970)................. 33

4.2. Anâlise estatística de dados obtidos...... 34

4:2.1. Primeira êpoca de semeadura ( 5 de maio de 1970) ................ 34

4.2.2. Segunda êpoca de semeadura ( 5 de de -

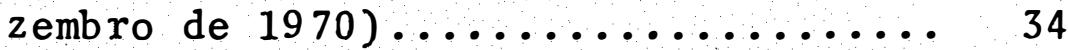

4.2.3. Considerações referentes às duas épocas de semeadura.............. 35

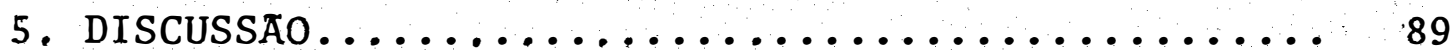

6 , CONCLUSOES......................... 94

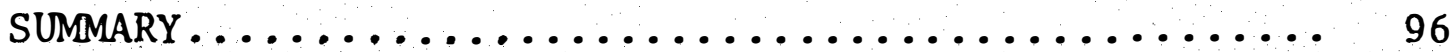

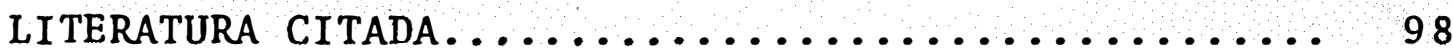




\section{LISTA DE TABELAS}

Tabela

1. Dados obtidos nas anâlises física e química de amostra de solo coletada na camada de ze ro a $25 \mathrm{~cm}$ de profundidade, no local onde se realizou o estudo do comportamento de cultivares de pepino em duas épocas de se meadura, no Centro Experimental de Campinas, nos anos de 1970 e $1971 \ldots \ldots \ldots \ldots \ldots \ldots \ldots$

2. Dados de temperatura, precipitação e insola ção coletados no Centro Experimental de Campinas, no período compreendido entre maio de 1970 e fevereiro de 1971, forneci dos pela Seção de Climatologia Agrícola do Instituto Agronômico do Estado de São Paülo

3. Localização das primeiras flores masculinas e femininas de cultivares de pepino semea das em 5 de maio de 1970 no Centro Experi menta1 de Campinas, em Campinas, SP........

4. Número de dias decorridos desde a emergên cia das plấntulas atê a abertura das primei ras flores masculinas e femininas de cultivares de pepino semeadas em 5 de maio de 1970 no Centro Experimental de Campinas, em

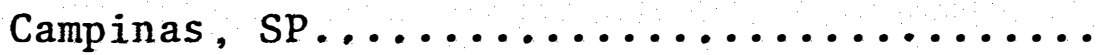

5. Localização das primeiras flores masculinas e femininas de cultivares de pepino semea das em 5 de dezembro de 1970 no Centro Experimental de Campinas, em Campinas, SP...... 
6. Número de dias decorridos desde a emergência das plântulas até a abertura das pri meiras flores masculinas e femininas de cultivares de pepino semeadas em 5 de de zembro de 1970 no Centro Experimental de

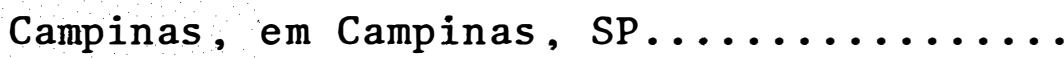

7. Médias do número de dias decorridos desde a emergência das plântulas até a primeira colheita, comprimento do ramo principal e número de ramos laterais das plantas em 7 de junho de 1970, em cultivares de pepino semeadas em 5 de maio de 1970 no Centro Ex perimental de Campinas, em Campinas, SP...

8. Mêdias das produções totais em peso de fru tos obtidas em cada colheita de cutivares de pepino semeadas em 5 de maio de 1970 no Centro Experimental de Campinas, em Campi-

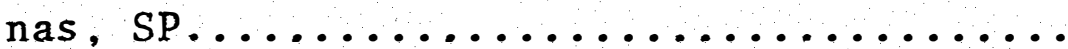

9. Mêdias das produções em peso de frutos comercialveis obtidas em cada colheita de cultivares de pepino semeadas em 5 de maio de 1970 no Centro Experimental de Campinas,

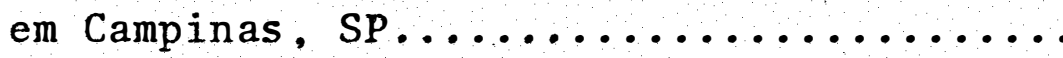

10. Coeficientes de correlação $(r)$ e respecti vos valores de $t$ entre diversas variảveis (X e Y) relativas âs cultivares de pepino Marketer, Palomar, Santee, Verde Paulistano e Aodai, semeadas em 5 de maio de 1970 no Centro Experimental de Campinas, em Cam pinas, SP..................... 
Tabela

11. Mêdias do número de dias decorridos desde a emergência das plântulas atê a primeira colheita, comprimento do ramo principal e numero de ramos laterais das plantas em 20 de janeiro de 1971 , em cultivares de pepino semeadas em 5 de dezembro de 1970 no Centro Experimental de Campinas, em Campinas, sp....................

12. Mêdias das produçōes totais em peso de frutos obtidas em cada colheita de cultivares de pepino semeadas em 5 de dezembro de 1970 no Centro Experimental de Campi nas, em Campinas, SP...............

13. Mêdias do nưmero total de frutos obtidos em cada colheita de cultivares de pepino semeadas em 5 de dezembro de 1970 no Centro Experimental de Campinas, em Campi -

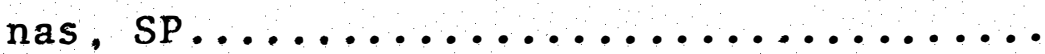

14. Mêdias das produções em peso de frutos comerciáveis obtidas em cada colheita de cultivares de pepino semeadas em 5 de dezembro de 1970 no Centro Experimental de Campinas, em Campinas. SP............

15. Coeficientes de correlação ( $r$ ) e respecti vos valores de $t$ entre diversas variáveis ( $X$ e Y) relativas âs cultivares de pepino Marketer, Palomar, Santee, Verde Paulista no e Aodai, semeadas em 5 de dezembro de 1970 no Centro Experimental de Campinas , em Campinas. SP.................. 
Tabela

Página

16. Comparações entre as mêdias obtidas para culfivares de pepino semeadas em 5 de maio e 5 de dezembro de 1970 no Centro Experimenta1 de Campinas, em Campi-

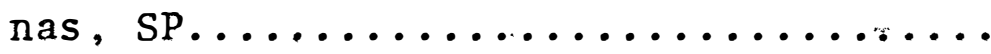




\section{LISTA DE FIGURAS}

Figura

Página

1. Sintomas de ataque de virose em frutos de plantas de pepino cv. Palomar IAC-3050 ob tidas por semeadura em 5 de maio de 1970 .

2. Sintomas de ataque de Pseudoperonospora cubensis (Berk. e Curt.) Rostow. em fo thas de plantas de diferentes cultivares de pepino obtidas por semeadura em 5 de dezembro de $1970 \ldots \ldots \ldots \ldots \ldots \ldots \ldots \ldots$

3. Sintomas de ataque de Margaronia sp. em frutos de plantas de pepino cv. Verde Pau 1istano IAC-1386 obtidas por semeadura em 5 de dezembro de $1970 \ldots \ldots \ldots \ldots \ldots \ldots \ldots$

4. Representação gräfica da produção em peso de frutos em relação à idade de plantas de diferentes cultivares de pepino obti das por semeadura em 5 de maio e 5 de dezembro de $1970 \ldots \ldots \ldots \ldots \ldots \ldots \ldots \ldots . . . .$.

5. Representação gräfica da porcentagem de produção de cada cultivar em relação ã produção total de todas as cultivares de pepino em duas épocas de semeadura......

6. Amostra de frutos da primeira colheita ( 7 de julho de 1970) de plantas de pepino cv. Marketer IAC- 2205 obtidas por semeadura em 5 de maio de $1970 \ldots . . . . . . . . . . .$.

7. Amostra de frutos da colheita de máior produção ( 3 de agosto de 1970 ) de pläntas de pepino cv. Marketer IAC-2205 obtidas por semeadura em 5 de maio de $1970 . . . .$. . 
Figura

Página

8. Amostra de frutos da última colheita ( 11 de agosto de 1970) de plantas de pepino cv. Marketer IAC- 2205 obtidas por semeadu

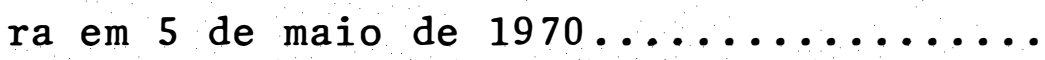

9. Amostra de frutos da primeira colheita ( 7 de julho de 1970) de plantas de pepino cv. Palomar IAC- 3050 obtidas por semeadu-

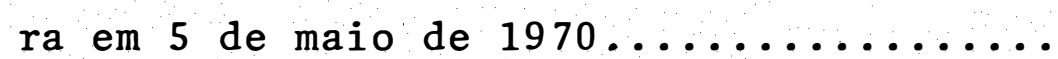

10. Amostra de frutos da colheita de maior produção (20 de julho de 1970$)$ de plantas de pepino cv. Palomar IAC- 3050 obtidas por semeadura em 5 de maio de $1970 \ldots \ldots$.

11. Amostra de frutos da última colheita (11 de agosto de 1970) de plantas de pepino cv, Palomar IAC- 3050 obtidas por semeadura em 5 de maio de $1970 . \ldots \ldots \ldots \ldots \ldots \ldots$

12. Amostra de frutos da primeira colheita (7 de julho de 1970) de plantas de pepino cv. Santee I-2441 obtidas por semeadura em 5 de maio de $1970 \ldots \ldots . . . . . . . . .$.

13. Amostra de frutos da colheita de maior produção ( 3 de agosto de 1970 ) de plantas de pepino cv. Santee I-2441 obtidas por semeadura em 5 de maio de $1970 \ldots . . . .$. 66

14. Amostra de frutos da última colheita (11 de agos to de 1970) de plantas de pepino cv. Santee I-2441 obtidas por semeadura em 5 de maio de $1970 \ldots \ldots . . . . . . . . .$.

15. Amostra de frutos da primeira colheita ( 7 de julho de 1970) de plantas de pepino cv. Verde Paulistano IAC-1386 obtidas por semeadura em 5 de maio de $1970 \ldots . . . .$. 
Figura

Página

16. Amostra de frutos da colheita de maior pro dução (16 de julho de 1970) de plantas de pepino cv. Verde Paulistano IAC-1386 obtidas por semeadura em 5 de maio de $1970 . .$.

17. Amostra de frutos da última colheita ( 11 de agosto de 1970) de plantas de pepino cv. Verde Paulistano IAC -1386 obtidas por se meadura em 5 de maio de $1970 \ldots \ldots \ldots \ldots$.......

18. Amostra de frutos da primeira colheita ( 7 de julho de 1970) de plantas de pepino cv. Aodai I-4321 obtidas por semeadura em 5 de

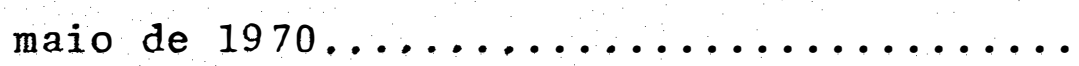

19. Amostra de frutos da colheita de maior pro dução ( 3 de agosto de 1970) de plantas de pepino cv. Aodai I-4321 obtidas por semeadura em 5 de maio de $1970 . \ldots \ldots \ldots . . .$.

20. Amostra de frutos da ültima colheita ( 11 de agosto de 1970) de plantas de pepino cv. Aodai I-4321 obtidas por semeadura em 5 de maio de $1970 \ldots \ldots \ldots \ldots \ldots \ldots \ldots \ldots . \ldots . \ldots$

21. Amostra de frutos da primeira colheita $(20$ de janeiro de 1971) de plantas de pepino cv. Marketer IAC-2205 obtidas por semeadura em 5 de dezembro de $1970 \ldots \ldots \ldots \ldots . .$.

22. Amostra de frutos da colheita de maior pro dução (25 de janeiro de 1971) de plantas de pepino cv. Marketer IAC- 2205 obtidas por semeadura em 5 de dezembro de $1970 \ldots$.

23. Amostra de frutos da ültima colheita ( 10 de fevereiro de 1971) de plantas de pepino cv. Marketer IAC-2205 obtidas por semeadura em 5 de dezembro de $1970 \ldots . . . . . .$. . 
xiv

Figura

Pảgina

24. Amostra de frutos da primeira colheita (20 de janeiro de 1971 ) de plantas de pepino cv. Palomar IAC-3050 obtidas por semeadura em 5 de dezembro de 1970

25. Amostra de frutos da colheita de maior produçāo ( 3 de fevereiro de 1971) de plantas de pepino cv. Palomar IAC- 3050 obtidas por semeadura em 5 de dezembro

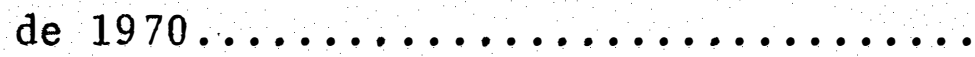

26. Amostra de frutos da ültima colheita (10 de fevereiro de 1971) de plantas de pepino cv. Palomar IAC-3050 obtidas por semeadura em 5 de dezembro de 1970

27. Amostra de frutos da primeira colheita (20 de janeiro de 1971 ) de plantas de pepino cr. Santee I-2441 obtidas por semeadura em 5 de-dezembro de 1970 ...

28. Amostra de frutos da colheita de maior produção ( 25 de janeiro de 1971) de plantas de pepino cv. Santee I- 2441 obtidas por semeadura em 5 de dezembro de $1970 \ldots \ldots \ldots \ldots \ldots \ldots \ldots \ldots \ldots \ldots \ldots \ldots \ldots \ldots \ldots \ldots \ldots$

29. Amostra de frutos da última colheita (10 de fevereiro de 1971) de plantas de pepino cv. Santee I-2441 obtidas por semeadura em 5 de dezembro de 1970

30. Amostra de frutos da primeira colheita (20 de janeiro de 1971) de plantas de pepino cv. Verde Paulistano IAC- 1386 obtidas por semeadura em 5 de dezembro de $1970 \ldots \ldots \ldots \ldots \ldots \ldots \ldots \ldots \ldots \ldots \ldots \ldots \ldots \ldots . . .$. 
Figura

31. Amostra de frutos da colheita de maior produção (1 de fevereiro de 1971) de plantas de pepino cv. Verde Paulistano IAC-1386 obtidas por semeadura em 5 de dezembro de $1970 \ldots \ldots \ldots \ldots \ldots \ldots \ldots$

32. Amostra de frutos da $\dot{u} 1$ tima colheita (10 de fevereiro de 1971) de plantas de pepino cv. Verde Paulistano IAC -1386 obtidas por semeadura em 5 'de dezembro de $1970 \ldots \ldots \ldots \ldots \ldots \ldots \ldots$

33. Amostra de frutos da primeira colheita (20 de janeiro de 1971) de plantas de pepino cv. Aodai I-4321 obtidas por semeadura em 5 de dezembro de $1970 \ldots$.

34. Amostra de frutos da colheita de maior produção ( 1 de fevereiro de 1971) de plantas de pepino cv. Aodai I-4321 obtidas por semeadura em 5 de dezembro de $1970 \ldots \ldots \ldots \ldots \ldots \ldots \ldots \ldots \ldots$

35. Amostra de frutos da ūltima colheita (10 de fevereiro de 1971) de plantas de pepino cv. Aodai I-4321 obtidas por semeadura em 5 de dezembro de $1970 \ldots$. 
$x v i$

"CURRI CULUM VITAE"

Maria Esmera1da Soares Payão Demattê nasceu em 13 de agosto de 1943 , em Bauru, SP.

Formou-se em 1966, na Escola Superior de Agri cultura "Luiz de Queiroz" da Universidade de São Paulo, em Pi racicaba, obtendo o título de Engenheiro-agrônomo.

Entre 1968 e 1974 , trabalhou no Instituto Agro nómico do Estado de São Paulo, em Campinas, desenvolvendo pes quisas sobre produção de hortaliças, especialmente as da famí lia Cucurbitaceae. Os resultados de seus trabalhos foram apresentados em congressos realizados no Brasil e no exte rior.

Desde 1974, é docente da Faculdade de Ciêncìas Agrärias e Veterinárias do "Campus" de Jaboticabal da Univer sidade Estadual Paulista "Julio de Mesquita Filho", estando Iigada ao Departamento de Fitotecnia. Orientou, até a presen te data, vinte e sete Trabalhos de Graduação de alunos do Cur so de Agronomía. 
RESUMO

0 comportamento das cultivares de pepino Marketer IAC-2205, Palomar IAC-3040, Santee I-2441, Verde Paulistano IAC-1386 e Aodai I-4321 foi estudado, em relação à produção de frutos para consumo in natura, em duas épocas de semeadura, em 5 de maio e 5 de dezembro de 1970 . O experimento foi realizado em Campinas, SP.

As produções foram maiores e qualidade dos frutos produzidos foi melhor na primeira época de semeadura.

$\mathrm{Na}$ primeira êpoca, as maiores produções foram ob tidas entre a quarta e a quinta, e entre a nona e a dêcima co 1heitas. Na segunda Época, as maiores produções concentraramse entre a terceira e a sétima colheitas.

De modo geral, as produções de cada colheita fo ram representativas da produção total. A produção total corre lacionou-se positivamente com a produção comerciâve1, assim có mo a produção em peso e o número de frutos produzidos. Com o aumento da idade das plantas, diminuiram o peso médio dos fru tos produzidos e a proporção de frutos comerciáveis. 
As $p l a n t a s$ mais produtivas apresentaram maior al tura e maịor nûmero de ramificaçôes laterais na época do in $\underline{\underline{r}}$ cio das colheitas.

Houve grande incidência de viroses atacando as plantas obtidas por semeadura em maio. Os frutos das plantas obtidas por semeadura em dezembro sofreram intenso ataque de larvas de Margaronia sp. Em ambas as épocas, observou-se inci dência de Pseudoperonospora cubensis prejudicando as follas das plantas.

Pela comparação do comportamento das diferentes cultivares, verificou-se que Aodai apresentou as maiores pro duções e os frutos de melhor qualidade, enquanto Santee foi a menos produtiva e seus frutos, de qualidade inferior. As pro duções das demais cultivares foram intermediárias. Verde Pau listano e Aodai produziram frutos de maior peso médio. A pro dução de Verde Paulistano foi mais tardia. Palomar e Verde Paulistano foram favorecidas pela semeadura em maio e Aodai, pe la semeadura em dezembro. o comportamento de Marketer foi pouco afetado pelas variaçōes ambientais. 


\section{INTRODUÇÃO}

o pepino é uma das hortaliças de maior importān cia econômica no Estado de São Paulo, como atestou MAKISHI MA (1973).

0 rendimento da cultura de pepino em condições brasileiras, entretanto, ainda não alcança os valores conse guidos por países de agricultura mais desenvolvida. Vários problemas, ainda não solucionados pela pesquisa, contribuem pa ra a queda de produtividade das plantas e para o prejuízo da qualidade do produto.

Um dos problemas que os produtores de pepino en frentam è a ocorrência, em proporção variâvel segundo a época de semeadura, de frutos danificados ou deformados, não comerciá veis. Pulverizações com defensivos, principalmente com inse ticidas, não devem ser feitas durante a fase de colheita, pelo perigo que os resîduos desses produtos representam para o con sumidor. Porisso, a produção das últimas colheitas, comumente, apresenta grande porcentagem de frutos danificados por doenças 
ou pragas, São, pois, necessârios estudos visando conhecer a êpoca mais adequada de semeadura das principais cultivares, em cada local, para produção de frutos de melhor qualidade.

Pelos motivos expostos, foi realizado o presente trabalho, em Campinas, SP, no ano de 1970. Seu objetivo foi comparar o comportamento de cinco cultivares de pepino em duas êpocas de semeadura, em relação à produção de frutos para con sumo in natura. 
Informaçöes pertinentes ao presente estudo, en contradas na revisão da literatura, estão distribuídas nos ítens apresentados a seguir.

2.1. Influência das condiçōes climâticas na cultura de pe pino

2.1.1. Informações gerais

De acordo com WHITAKER a DAVIS (1962), as Cucur bitaceae requerem grande intensidade de luz solar e longo pe ríodo de temperaturas elevadas durante o seu ciclo, não supor tando geadas. São plantas que se desenvolvem melhor em épocas secas, pois, nos períodos úmidos, são mais suscetíveis a doen ças.

KAYOTP (1966) e FILGUEIRA (1972) consideram o pe pino uma hortalíça de clima tropical, exigente em temperaturas elevadas e sem resistência ao frio. 
Segundo FILGUEIRA (1972), na maioria das regiôes brasileiras, o pepino é semeado entre os meses de agosto e abril, para que as plantas se desenvolvam em condições climátí cas adequadas.

TERRA (1966) afirmou que a maioria das cultiva res de pepino não apresenta boa tolerância a chuvas. A flora ção pode ser afetada por umidade excessiva e as folhas podem ser danificadas por ventos fortes.

2.1.2. Influência da temperatura na germinação das sementes

Segundo KNOTT (1966), as sementes de pepino ger minam em temperaturas do solo compreendidas na faixa de $15,5^{\circ} \mathrm{C}$ e $35,0^{\circ} \mathrm{C}$.

De acordo com Harrington e Minges (1954), cita dos por WHITAKER e DAVIS (1962), a temperatura ótima para ge $\underline{r}$ minação de sementes de pepino ê de aproximadamente $35,0^{\circ} \mathrm{C}$.

SEGET'A (1966 a e b) estabeleceu que a temperatu ra mînima do solo para germinação de sementes de pepino é de $12,0 \circ \mathrm{C}$. Abaixo dessa temperatura, a germinação é inibida diré tamente pe10 frio. $\mathrm{Na}$ faixa compreendida entre $12,0^{\circ} \mathrm{C}$ e $16,0^{\circ} \mathrm{C}$ a emergência das plântulas é prejudicada principalmente por microorganismos patogênicos.

SEGET'A e TRONIČKOVA (1966) observaram que, em temperatura favoráve1, amostras de sementes de diferentes ida des da mesma cultivar ou de diferentes cultivares de pepino, co 1 hidas em diferentes locais, nẫo diferiram muito quanto à por centagem de germinação.

Entretanto, na faixa de temperatura compreendida entre $12,0^{\circ} \mathrm{C}$ e $23,0^{\circ} \mathrm{C}$, NILSSON (1968) e SCHULTE e GROTE (1974) relataram que a porcentagem de germinação de sementes de pepi no é específica para cada cultivar. 
2.1.3. Influência da temperatura e da umidade no de senvolvimento das plantas

Trabalhos de MILTHORPE (1959) e FÖLSTER

(1974

a e b) demonstraram que as temperaturas do ar ou do solo mais a dequadas para o desenvolvimento de pepino estão compreendidas entre $24,0^{\circ} \mathrm{C}$ e $32,0^{\circ} \mathrm{C}$.

Schroeder (1939), citado por WHITAKER e DAVIS

(1962), relatou que plantas de pepino não se desenvolveram sa tisfatoriamente em temperaturas do solo de $15,6^{\circ} \mathrm{C}$, requerendo temperaturas mais elevadas.

Em estudo feito em cas a de vegetação por FöLSTER (1974 a), a temperatura mínima para o desenvolvimento de piântú las de pepino foi $16,0^{\circ} \mathrm{C}$.

MILLER e QUISENBERRY (1976) verificaram que tempe raturas baixas retardam o florescimento e a época de colheita de pepino, pelo atraso de desenvolvimento das plantas e pelo aumento do número de nós até o aparecimento da primeira flor feminina.

Entre as variâveis climatológicas, SEATON e KRE MER (1939) consideraram a temperatura como sendo a de influên cia mais importante na antese e deiscência da antera em pepino. Os resultados encontrados por esses autores mostraram que a fai xa de temperatura ótima para a deiscência dos sacos polínicos está compreendida entre $18,0^{\circ} \mathrm{C}$ e $21,0^{\circ} \mathrm{C}$, sendo de $15,0^{\circ} \mathrm{C}$ a tem peratura mínima para que a deiscência ocorra.

Hayase (1955), citado por MATLOB e KELLY (1973), demonstrou que a mâxima viabilidade do pólen de pepino ocorre na faixa de temperatura compreendida entre $20,0^{\circ} \mathrm{C}$ e $25,0^{\circ} \mathrm{C}$; es sa viabilidade decresce com o aumento da temperatura e da umi dade.

Em trabalho posterior, HAYASE (1961) verificou que a viabilidade do pólen de pepino decresce com o aumento da temperatura, quando a umidade relativa do ar é baixa, a viabilí dade do pólen é menor em todas as temperaturas. As condições 
- favoräveis para a viabilidade do pôlen, são $80 \%$ de umidade re lativa do ar e temperatura ambiente de $10,0^{\circ} \mathrm{C}$.

MATLOB e KELLY (1973) relataram que a temperatura ôtima para germinaçāo do pôlen e crescimento do tubo polínico, em pepino, ê $21,0^{\circ} \mathrm{C}$. A faixa tolerada pelo pólen, em relação à sua viabilidade, estâ compreendida entre $10,0^{\circ} \mathrm{C}$ e $43,0^{\circ} \mathrm{C}$.

Gregory (1928), citado por WHITAKER e DAVIS (1962), verificou que, em plantas jovens de pepino, quando a temperatú ra elevou-se acima de $29,1^{\circ} \mathrm{C}$, a taxa de crescimento da folha de cresceu rapidamente.

A expansão relativa da superfície foliar de pepí no é, segundo MILTHORPE (1959), maior a 24,08C.

A área foliar tem importante influência na produ ção de frutos de pepino, como demonstraram PARR e HUSSEY (1962). No experimento realizado por esses autores, a remoção de $50 \%$ de ärea foliar provọcou redução de $25 \%$ no número de frutos forma dos.

De acordo com TATSUMI e HORI (1970), a máxima ta xa fotossintêtica ocorre, em pepino, na faixa de temperatura compreendida entre $15,00^{\circ} \mathrm{C} 20,0^{\circ} \mathrm{C}$, independentemente da inten sidade luminosa.

Os trabalhos de ALEX (1957) e AMARAL et aliz (1963) demonstram que o pepino, para produzir frutos em quan tidades satisfatōriaś, necessita da presença de insetos polini zadores; o principal agente polinizador de flores de pepino é a abeiha (Apis melizfera L.).

De acordo com Heran (1952), citado por RIBBANDS (1953), a abelha tem melhores condiçōes para atividade na faixa de temperatura compreendida entre $31,5^{\circ} \mathrm{C}$ e $36^{\circ}, 5^{\circ} \mathrm{C}$.

WHITEHEAD (1954) afirmou que as abelhas podem tra balhar 1 ivremente apenas em temperaturas superiores a $13,0^{\circ} \mathrm{C}$.

Segundo CHAUVIN (1968), quando a temperatura está compreendida entre $5,0^{\circ} \mathrm{C}$ e $10,0^{\circ} \mathrm{C}$, a maior parte do enxame de abelhas recolhe-se ao interior da colmeia. 
A temperatura ambiente influi na intensidade de ataque de mosaico de pepino. DORSET (1975), com base em dados experimentais, recomenda que o pepino seja cultivado em tempe raturas diurnas e noturnas maiores que $21,0^{\circ} \mathrm{C}$, para evitar a taque intenso de CMV ("cucumber mosaic virus").

2.1.4. Influência de algumas características da luz no desenvolvimento das plantas

DANIELSON (1944) observou que as dimensōes do caule, folha e raiz de pepino, bem como sua composição química, em vârias fases de crescimento, foram peculiares a cada fotope ríodo, quando as plantas foram cultivadas em 8,12 ou 16 horas de luz por dia. O comprimento do caule foi mâximo em 8 horas de luz por dia e menor em fotoperíodo de 16 horas. A diferen ça de resposta em crescimento vegetativo foi mais evidente na época de formação de flores, sugerindo uma possível relação fi siolôgica entre o crescimento do caule e a floração.

Como demonstrou o trabalho de BOOS (1963), a res posta a fotoperiodo varia entre diferentes cultivares de pepi no.

De acordo com Gregory (1921), citado por WHITÁ KER e DAVIS (1962), sob condiçōes semelhantes, a área foliar média de pepino é determinada pela intensidade e duração da radiação luminosa, o que foi posteriormente confirmado por MIL THORPE E NEWTON (1963).

Iluminação por 12 horas por dia manteve o suprí mento de carboidrato da folha de pepino adequado para o cres cimento ôtimo, em trabalho de PORTHSMOUTH (1937).

Em estudo de NEWTON (1963), a expansão foliar e o aumento de peso de plantas secas de pepino foram maiores em fotoperíodos de 10 a 15 horas.

Experimento de PLOEGMAN e BIERHUIZEN (1970) mos trou que, com a diminuição da intensidade luminosa, há redução no teor de matéria seca de pepino. 
TIEDJENS (1928 b) recomendou que as polinizações artificiais, em pepino, sefam feitas durante dias de mảxima in tensidade luminosa, para que haja fertilização adequada antes do início do crescimento do ovärio; nesses dias, hả também me nor tendência dos frutos a se desenvolveram partenocarpicamen te. A medida que a quantidade de 1 uz decresce em intensidade e duração, hâ tendência gradual da planta para resposta em cres cimento vegetativo, isto é, menor estímulo é necessário para o início do desenvolvimento do fruto e muitas plantas podem produ zir frutos partenocârpicos. Hā produção de maior número de fru tos deformados durante dias de intensidade luminosa reduzida.

\subsubsection{Influência de fatores climáticos na expressão do sexo}

SHIFFRISS e GALUN (1956) estabeleceram que, em pe. pino, o nümero de nós compreendidos entre as folhas cotiledonares e o nó em que aparece a primeira flor feminina é aproximada mente constante numa determinada cultivar, sendo uma caracterís tica controlada geneticamente. Esse número de nós é um bom ín dice da tendência sexual e da precocidade da cultivar.

MILLER e QUISENBERRY (1976) verificaram que o nuu mero de dias decorridos desde a emergência das plântulas até a floração está mais relacionado com a época de colheita de pe pino do que a taxa de emergência das plântulas. 0 coeficiente de correlação obtido entre a êpoca de floração e a época corres pondente à média das datas das diversas colheitas foi de 0,82 .

Como demonstrou GALUN (1961), a expressão do se xo, em pepino, é controlada, em princípio, geneticamente.

ATSMON e GALUN (1962) verificaram que, no início de desenvolvimento, as gemas florais de pepino são potencial mente bissexuais, com rudimentos de androceu e gineceu. Poste riormente, apenas um dos sexos se desenvolve, dependendo da constituição genética da planta, da posição da flor no ramo principal e das influências ambientais ou hormonais. 
FUKUSHIMA et alii (1968) observaram que, nas cu tivares de pepino monóicas, as flores femininas tenderam a ser mais frequentes nas partes distais do caule. De modo geral, baixas temperaturas induziram a produção de flores femininas. 0 fotoperîodo teve influência variâvel conforme a cultivar.

Resumindo dados obtidos por diversos pesquisado res, GUARDIA C. (1970) informou que a temperatura diurna ótima para a formação de flores femininas, que dão origem aos frutos, estâ compreendida entre $17,0^{\circ} \mathrm{C}$ e $24,0^{\circ} \mathrm{C}$.

NITSCH et aliz (1952) estudaram o efeito do foto período combinado com temperatura sobre a expressão do sexo em pepino monóico. Alta temperatura e dias longos tenderam a man ter a planta na fase masculina, enquanto baixa temperatura e dias curtos apressaram o desenvolvimento da planta, com forma ção de flores femininas depois do menor número de nós.

Diversos trabalhos como os de GALUN (1961), SAITO (1961) e ATSMON (1968), confirmaram as conclusões a que chega ram NITSCH et àliz (1952).

De acordo com SAITO (1961), a formação de flores femininas $\vec{e}$ induzida em temperaturas inferiores a $17,09 \mathrm{C}$ e, pa ra que se diferenciem flores femininas, são necessários nove pe ríodos escuros de 8 horas ou três períodos escuros de 12 horas. A cultivar Marketer é pouco sensível à variação de fotoperíodo, segundo SHIFFRISS e GEORGE (1965).

0 efeito da intensidade luminosa na expressão do sexo de pepino foi inicialmente estudado por TIEDJENS ( 1928 a). Esse autor verificou que, elevando-se a intensidade luminosa, há tendência a aumentar, dentro de certos limites, o número de flores femininas e diminuição no número de flores masculinas.

Mining e Matzekevitch (1944), citados por WHITAKER e DAVIS (1962), verificaram que alta umidade acelerou o apa recimento de flores femininas e baixa umidade, o de flores mas culinas, em pepino cv. Nerosinge. 
2.2. Influência da localizaçẫo dos frutos na planta sobre. a produçẫo total

TIEDJENS (1928 b) afirmou que as cultivares de pepino que apresentam flores femininas apenas nos ramos 1ate rais produzem maior proporção de frutos bem formados, porque a primeira frutificação, aquela em que há produção de frutos de melhor qualidade, e mais intensa.

De acordo com STENE (1964), os frutos produzidos nos primeiros nôs do caule de pepino são, frequentemente, de qualidade inferior.

2.3. Correlação entre a produção e outras variáveis

Segundo SRIVASTAVA et alî (1972), a produção de uma planta e resultado da interação entre certo número de ca racterísticas, bem como da interação entre essa planta e o ambiente.

Diversos pesquisadores, trabalhando com diferen tes culturas, encontraram correlação positiva entre a produ ção em peso por planta e o nưmero de frutos por planta: SIKKA e GUPTA (1949), em gergelim; JOHNSON et alii (1955), em soja ; PAVATE e MURTY (1963), em fumo; SHARMA e SWARUP (1964), em re po1ho; CHAUDHARY (1967), em mortarda; MITAL et alii (1969), MI TAL e THOMAS (1969) e SINGH e MEHNDIRATTA (1969), em leguminosas forrageiras; SRIVASTAVA et alii (1972), em ervilha; ABDEL-AL et alii (1973), em Cucurbita maxima; SINCH et alii (1974), em tomate.

Correlação entre produção e comprimento da plan ta tem sido constatada para algumas espécies vegetais.

Em milho, essa correlação foi estudada em numero sos trabalhos, entre os quais os de SWAMY RAO et alii (1970) e EL-LAKANY e RUSSELL (1971), que encontraram correlação posìti va entre produção e altura da planta de algumas cultivares, e o de MOLL e STUBER (1971), que encontraram correlação negatí va entre essas variáveis para outras cultivares. 
SHIH (1948) e SIKKA e GUPTA (1949) verificaram que houve correlação positiva entre a produção, respectivamente, de soja e gergelim, e a altura das plantas, bem como entre a pro dução e o número de ramos dessas plantas.

NIGMANOVA (1963), estudando aboboreira do tipo "vegetable marrow" (Cucurbita sp.), planta da mesma família do pepino, verificou que, em cultivares de ramos mais longos, o nú mero de frutos, o peso médio dos frutos e a produção total fo ram maiores.

Aumento de produção associado a maior comprimento dos ramos também foi observado em Cucurbita maxima "E1-Askandarani" por ABDEL-AL et aliz (1973).

Outros autores também estudaram os componentes da produção de plantas da família Cucurbitaceae.

Assim, GREBENSCIKOV (1963 e 1967) realizou estu dos com Cucurbita pepo L. e C. maxima Duchesne. o nümero e o peso total dos frutos variaram muito de ano para ano, enquanto o peso médio do fruto foi pouco afetado pelo ambiente.

A produção de melancia foi estudada por SACHAN e TIKKA (1971). Essa produção correlacionou-se com o comprimen to do ramo principal, com o numero de ramificações laterais prí märias, com o número de dias até o aparecimento da primeira flor feminina e com o peso médio dos frutos. A herdabilidade estimada e o ganho genético indicaran que o peso do fruto, a produção e a taxa do sexo das flores podem ser aumentados por seleção.

THAMBURAJ (1973) verificou que o peso e o comprí mento dos frutos de Luffa acutangula L. foram positivamente correlacionados com a produção.

CARLSSON (1962), trabalhando com pepino, encon trou clara correlação entre o peso mêdio do fruto e seu comprí mento.

RAMALHO (1973) constatou que, na cultivar Aodai, o número de flores femininas apresenta correlaçōes genotípicas positivas com o número de frutos, e negativas com o peso, com 
primento e porcentagem de pegamento dos frutos. Nos frutos, maior comprimento foi positivamente correlacionado com maior peso. Houve tambêm correlaçẫo posittiva entre maior produção to tal e maior produçāo comercîâvel. A ocorrência de flores femi ninas na haste central foi negativamente correlacionada com pe gamento, nümero, comprìmento, peso e produção de frutos, o que est $\vec{a}$ de acordo com a teoria proposta por TIEDJENS (1928 b).

\subsection{Comportamento das cultivares estudadas}

A produtividade das cultivares de pepino estuda das neste trabalho tem sido variāvel, conforme o local, os tra tos culturais empregados e a época em que o experimento foi realizado.

Em.trabalho feito em Pavas, Costa Rica, por MU RILLO et alii (1963), a cultivar Palomar apresentou boa produ tividade. As plantas foram cultivadas em solo argiloso compac tado, ligeiramente inclinado, de drenagem lenta, pobre em maté ria orgânica e em nutrientes. As temperaturas médias mensais durante a rea1ização do experimento variaram de $20,8^{\circ} \mathrm{C}$ a $21,4^{\circ} \mathrm{C}$ e as precipitaçōes totais mensais variaram de $173,9 \mathrm{~mm}$ a 433,7 $\mathrm{mm}$.

DEMATTE et alii (1970 e 1975) observaram o com portamento das cultivares Marketer, Palomar, Santee, Verde Pau istano e Aodai. Em estudo realizado entre agosto e dezembro de 1968, em Jundiaí, SP, verificou-se que as cultivares Verde Paulistano, Santee e Marketer foram mais produtivas que outras cultivares estudadas, sem diferir entre si; Palomar apresentou produtividade 1 igeiramente inferior. Em Campinas, SP, entre setembro e dezembro de 1969, Marketer, sem diferir de Verde Pau listano, destacou-se por sua alta produtividade e boas qualida des comerciais dos frutos; Verde Paulistano apresentou frutos com sabor amargo na regiāo pröxima ao pedúncu1o. Em experimeñ to realizado em Campinas, SP, entre janeiro e março de 1973 , Ao 
dai colocou-se entre as cultivares de pepino de maior produtivi dade, apresentando frutos de boa qualidade; Verde Paulistano e Santee foram as cultivares de comportamento menos adequado, por terem apresentado baixa produtividade e outras características indesejāveis: frutos ocos e de sabor amargo em Verde Paulista no, e alta porcentagem de frutos curvos e plantas suscetiveis a viroses em Santee; entretanto, os frutos de Santee estiveram en tre os que se conservaram em boas condições por maior tempo de pois de colhidos.

Em 1972 as cultivares Marketer, Palomar e Aodai fo ra, estudadas por DEMATTE et alï (1974) em Campinas, SP, sob dois sistemas de irrigação, subterrânea e por aspersão. Quando irrigadas por aspersão, Marketer e Aodai foram superiores a Pa lomar em produção de frutos com forma e aparência normais. Quan do irrigadas por via subterrânea, as cultivares não diferiram entre si quanto à produção de frutos.

De acordo com CASTRO et aliz (1972), a cultivar Aodai, por sua alta produtividade, alcançou expressiva populari dade entre os produtores de pepino, conquistando preferência nos grandes centros consumidores. Em experimento realizado por esses autores, no Estado do Rio de Janeiro, com semeadura em ou tubro de 1970 , duas seleções de Aodai apresentaram frutos de boa qualidade, com peso médio de $388 \mathrm{~g}$ (seleção Horticeres) e $372 \mathrm{~g}$ (seleção UFRRJ); as produções por planta foram 9,8 fru tos pesando $3400 \mathrm{~g}$ (seleção Horticeres) e 6,2 frutos pesando $2309 \mathrm{~g}$ (seleção UFRRJ). Nesse estudo, as cultivares do tipo Aodai apresentaram frutos de maior peso médio, mas menor núme ro de frutos por planta, em relação às cultivares de origem nor te-americana estudadas.

Em estudo realizado em Morretes, PR., GOMES et alii (1974) não encontraram diferenças significativas entre a produção de frutos de pepino das cultivares Aodai, Palomar, Mar keter e Verde Paulistano.

CASTRO et alii (1976) observaram que, entre dive $\underline{r}$ sas cultivares de pepino estudadas, a maior incidência de Mar 
garonia spp. verificou-se sobre a cultivar Verde Paulistano Santee foi uma das menos infestadas. Marketer e Palomar mostra $\mathrm{ra}$, infestação variâvel entre plantas da mesma parcela.

A maior suscetíbilidade de Cucurbitaceae ao ata que de Diabrotica undecimpunctata howardi (vaquinha pintada), D. balteata e Acalyma vittata (vaquinha rajada) está associada à presença de substâncias que conferem sabor amargo às plantas (cucurbitacinas), como demonstraram CHAMBLISS e JONES (1966) , SHARMA e HALL (1971), COSTA e JONES (1971) e HAYNES e JONES (1975).

Considerando que a cultivar Verde Paulistano, se gundo DEMATTE et ali $i$ (1970 e 1975), apresenta frutos de sabor amargo, e que a cultivar Marketer é considerada por cosTA e Jo NES (1971) como sendo de constituição genética BiBi (amargo), é possível que a preferência de Margaronia spp. pela cultivar Ver de Paulistano e, em menor intensidade, pela cultivar Marketer , relatada por CASTRO et alizi (1976), seja ocasionada pela pre sença de cucurbitacinas nas plantas das cultivares citadas.

Brett (1962 e 1963), citado por SULLIVAN e BRETT (1971), observou que a cultivar Marketer apresenta moderada re sistência de folhagem ao ataque de Diabrotica undecimpunctata howardi. Essa observação pode ser explicada pela provável não ocorrência de cucurbitacinas na folhagem das plantas da culti var Marketer, pois, de acordo com WHITAKER e DAVIS (1962), as concentrações mais altas de cucurbitacinas são encontradas nos frutos e nas raízes, sendo as folhas e os caules geralmente não amargos ou apenas ligeiramente amargos.

NUTTAL e JASMIN (1958) consideraram a cultivar Marketer suscetível a murcha bacteriana causada por Erwinia tra cheiphila (E.F.Sm.) Holland, que, segundo COSTA e JONES (1971), é disseminada por Diabrotica undecimpunctata howardi, D. baltea ta e Acalymma vittata, insetos que atacam plantas amargas, de pepino.

BARNES e EPPS (1956) relataram que as cultivares Palomar e Santee apresentam resistência moderada a oídio (Ery siphe cichoracearum De Candolle). 
WHITAKER e DAVIS (1962) consideraram as cultìva res Palomar e Santee resistentes a mîlidio [Pseudoperonospora cubensis (Berk \& Curt.) Rostow.].

A cultivar Palomar também foi citada como resis tente a míldio por MURILLO et alii (1963).

LAVALLEE (1967) observou que a cultivar Marketer apresenta resistêncìa moderada a cládosporium cucumerinum El1. \& Art., enquanto Palomar é suscetível.

CASTRO et alii (1972) constataram que a cultivar Aodai é suscetível a antracnose (Colletotrichum lagenarium) , míldio e oídio.

MITIDIERI et alii (1963) determinaram que a pro porção entre flores femininas e flores masculinas, na cultivar Aodai, foi em média, de $1: 21,6$, em plantas obtidas por semeadu ra em janeiro de 1963, em Piracicaba, SP.

CASTTRO et alii (1973) estudaram a distribuição de flores femininas em duas seleções da cultivar Aodai e ver ficaram que $80 \%$ das plantas apresentaram, no ramo principal, a primeira flor feminina em nós cujos nümeros médios foram 21,33 (seleção C.A.C.) e 18,33 (seleção Horticeres).

RAMALHO (1973) verificou que, na cultivar Aodai, as flores femininas ocorrem principalmente no primeiro nó das ramificações laterais. 
3. MATERTAL E METODOS

Para a realização deste experimento, foram utili zados o material e os mêtodos que estão descritos a seguir.

\subsection{Caracterização do local do experimento.}

A área experimental utilizada localiza-se no Cen tro Experimental de Campinas do Instituto Agronômico do Esta do de São Paulo, situado no município de Campinas, SP.

De acordo com informação de MELFI et alii (1966)

- Centro Experimental de Campinas encontra-se a $22^{\circ} 52^{\prime}$ de 1 at tude sul e 47904' de longitude oeste $G$, na vertente noroeste do mais alto espigão da cidade de Campinas, a uma altitude que varia de $721 \mathrm{~m}$ a $601 \mathrm{~m}$. A média de precipitação pluvial anual è de $1364 \mathrm{~mm}$ e a temperatura média anual, de $20,5^{\circ} \mathrm{C}$. A árëa é, em grande parte, coberta por experimentos de campo, apresen tando apenas resquícios de vegetação original, composta de flo resta tropical sempre verde. 
o local onde este experimento foi conduzido deno mina-se "Ponte Seca" e seu solo ê classificado como Latossolo Vermelho Amare1o, fase arenosa,

As principais características físicas e químicas desse solo, na ärea do experimento, determinadas imediatamente antes do inî́cio do estudo, são apresentadas na Tabela 1 .

o local apresenta as qualidades que couTo (1959)

considerou favorâveis à cultura de hortaliças: a camada superfi cial do solo não é excessivamente argilosa (Tabela 1) e o ter reno é ligeiramente inclinado e bastante ensolarado.

As temperaturas mêdias, mâximas e mínimas mensais, as precipitações pluviais totais mensais e a insolação total mensal registradas no local, durante a realização do experimento, encontram-se na Tabela 2 .

3.2. Caractèrização das plantas estudadas.

\subsubsection{Classificação botânica}

o experimento foi feito com a espêcie Cucumis sa tivus L. (pepino), pertencente à família Cucurbitaceae.

3.2.2. Informações sobre as cultivares estudadas

As cultivares utilizadas foram Marketer IAC-2205, Palomar IAC-3050, Santee I-2441, Verde Paulistano IAC-1386 e Aodai I-4321. A partir deste capítulo, a fim de se evitarem repetições desnecessârias, as cultivares serão designadas ape nas por Marketer, Palomar, Santee, Verde Paulistano e Aodai.

As informações referentes à introdução das culti vares na Seção de Hortaliças de Frutos do Instituto Agronômico do Estado de São Pau1o, extraídas dos livros de registro da re ferída Seção, e a deścrição dessas cultivares são apresentadas a seguir. 
- Tabela 1. Dados obtidos nas análises física e química de amos tra de solo coletada na camada de zero a $25 \mathrm{~cm}$ de profundidade, no local onde se realizou o estudo do comportamento de cultivares de pepino em duas épocas de semeadura, no Centro Experimental de Cam pinas, nos anos de 1970 e 1971. (As anālises foram feitas pelas Seções de Pedologia e Fertilidade do So 10 do Instituto Agronômico do Estado de São Paulo).

Características

Valores determinados

Argila $\left(\begin{array}{l}0 \\ 0\end{array}\right)$

28,00

Limo $\left(\begin{array}{l}\circ \\ 0\end{array}\right)$

13,50

Areia fina $\left(\frac{0}{0}\right)$

24,50

Areia grossa

$\left(\begin{array}{l}0 \\ 0\end{array}\right)$

34,00

Classe textural

argiloso

Capacidade de campo ( $\left(\begin{array}{l}0 \\ 0\end{array}\right)$

20,00

Ponto de murchamento permanente $\left(\begin{array}{l}0 \\ 0\end{array}\right)$

10,70

Densidade aparente $\left(\mathrm{g} / \mathrm{cm}^{3}\right)$

0,90

$\mathrm{pH}$

5,50

C $\left(\begin{array}{l}0 \\ 0\end{array}\right)$

1,60

$\mathrm{PO}_{4}^{--}(\mathrm{e} . \mathrm{mg} / 100 \mathrm{ml}$ T.F.S.A.) a/

0,26

$\mathrm{K}^{+}(\mathrm{e} . \mathrm{mg} / 100 \mathrm{ml}$ T.F.S.A. $)$

0,44

$\mathrm{Ca}^{++}+\mathrm{Mg}^{++}(\mathrm{e} . \mathrm{mg} / 100 \mathrm{ml}$ T.F.S.A.)

1,90

$\mathrm{Al}^{+++}(\mathrm{e} . \mathrm{mg} / 100 \mathrm{ml}$ T.F.S.A.)

traços

a/ T.F.S.A. = terra fina seca ao ar (partículas menores que $2 \mathrm{~mm}$ ). 


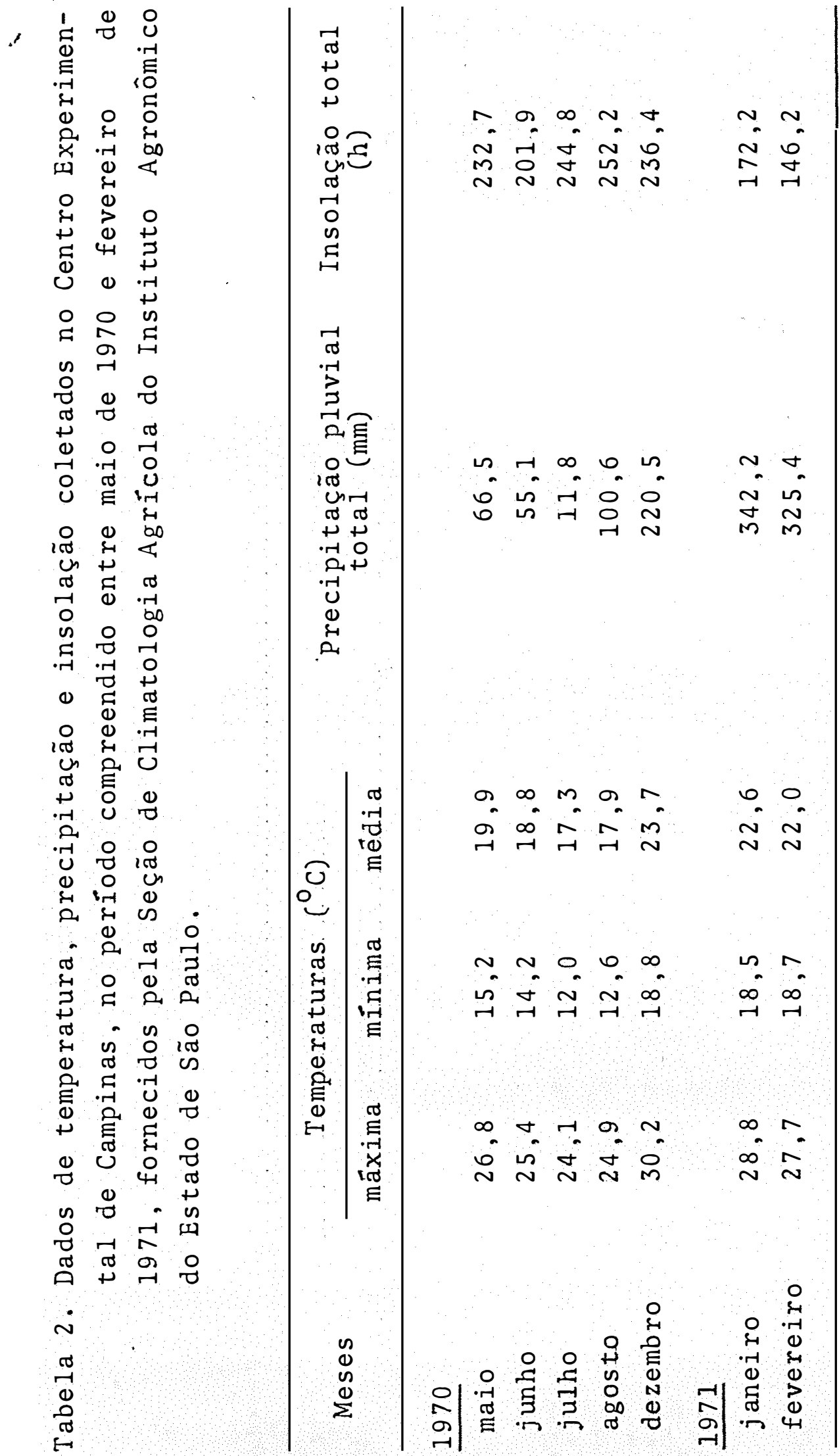


Esta cultivar foi introduzida em 17 de maio de 1954, sob o $n^{\circ}$ 2205, procedente da firma W. Atlee Burpee Co., Philadelphia, Pa., U.S.A. Na Seção de Introdução de Plantas do Instituto Agronômico do Estado de São Paulo, recebera anterior mente o $\mathrm{n}^{\circ} \mathrm{I} .17 .429 .4 .6 .03$.

De acordo com WHITAKER e DAVIS (1962), esta cu tivar foi lançada pela Asgrow Seed Co. (New Haven, Connecticut, U.S.A.) .

CAMPOS e PAYAO (1969) informaram que as plantas da cultivar Marketer apresentam ramos que atingem $2 \mathrm{~m}$ ou mais de comprimento e seus frutos, no ponto de consumo, medem apro ximadamente $17 \mathrm{~cm}$ de comprimento.

\subsubsection{Palomar}

Esta cultivar foi introduzida em 27 de março de 1960, sob o n: 3050, procedente da firma Ferry-Morse Seed Co., Detroit, Michigan, e Mountain View, California, U.S.A. Na Seção de Introdução de Plantas do Instituto Agronômico do Esta do de São Paulo, recebera anteriormente o n:24.627.

De acordo com WHITAKER e DAVIS (1962), esta cu1 tivar foi lançada pela Ferry-Morse Seed Co.

Segundo CAMPOS e PAYAO (1969), as plantas de Pa lomar apresentam ramos de $1,80 \mathrm{~m}$ de comprimento e frutos de coloração verde-escuro, com comprimento médio de $18 \mathrm{~cm}$ e diâa metro transversal mêdio de $4 \mathrm{~cm}$; a polpa dos frutos ê macia, espessa e de coloração clara, com âmago reduzido e sem vazios. Esta cultivar ê altamente produtiva, comparâvel a Aodai quan to à produtividade, e seus frutos assemelham-se aos de Marke.ter. 


$$
3,2,2,3 \text {. Santee }
$$

Esta cultivar foi introduzida em 22 de setembro de 1955 , sob o $n^{\circ} 2,441$, designada por Linhagem $W x-11$, proceden te da firma Lawrence Robinson \& Sons, Modesto, California, , U.S.A.

WHITAKER e DAVIS (1962) relataram que esta culti var foi lançada pela South Carolina Experiment Station (Charles ton South Carolina, U.S.A.).

De acordo com CAMPOS e PAYAO (1969), a cultivar Santee apresenta ramos que atingem até $1,60 \mathrm{~m}$ de comprimento, tem produtividade equivalente a Palomar e frutos de aparência semelhante aos de Marketer, com aproximadamente $16 \mathrm{~cm}$ de com primento.

\subsubsection{Verde Paulistano}

Esta cultivar foi introduzida em 14 de fevereiro de 1948, sob o n' 1386 , com o nome de Aodai, procedente da Co operativa Agrícola de Cotia, Estado de São Paulo.

A Seção de Hortaliças de Frutos do Instituto Agro nômico do Estado de São Paulo, nos Relatórios Anuais posterio res a 1948 (não publicados), passou a designar esta cultivar por Verde Paulistano.

A cultivar Verde Paulistano, segundo CAMPOS $\mathrm{e}$ PAYAO (1969), pode ser considerada um tipo de Aodai e é muito produtiva, com ramos de $3 \mathrm{~m}$ ou mais de comprimento e frutos grandes, de coloração externa verde-claro que, internamente, a presentam alguns defeitos: polpa pouco espessa um tanto rija, â mago muito desenvolvido e ocorrência de ocos.

\section{2 .2 .5 . Aodai}

Esta cultivar foi introduzida em 5 de maio de 1970, sob o n 4.321 , procedente da Cooperativa Agrícola de Co tia, Estado de São Paulo. 
De acordo com DEMATTE et azii (1975), a cultivar Aodai produz frutos de tipo apreciado pelo mercado paulista, mas que podem apresentar sabor amargo; esses frutos tềm casca de coloração verde-escuro, com estrias verde-claro saindo da extremidade ligada à flor e espinhos em nümero médio, brancos e achatados.

\subsection{Dados culturais.}

$\mathrm{Na}$ instalação, condução e colheitas do presente experimento, observaram-se as práticas que se seguem. 0 prepa ro do terreno, a semeadura, os tratos culturais e a colheita fo ram feitos com base nas instruções de CAMPOS e PAYÃO (1969).

\subsubsection{Epocas de semeadura}

As épocas de semeadura foram duas, em 5 de maio de 1970 e em 5 de dezembro de 1970. O local utilizado para a cultura foi o mesmo nas duas épocas.

3.3.2. Preparo do solo, preparo das covas e espaça mento

Nas duas épocas de semeadura, o solo foi previa mente arado, gradeado e sulcado.

Sete dias antes da semeadura de cada epoca, foi distribuída por metro linear de sulco a seguinte quantidade de adubos: $3500 \mathrm{~g}$ de composto orgânico curtido, $360 \mathrm{~g}$ de superfos fato simples $\left(20 \%\right.$ de $\left.\mathrm{P}_{2} \mathrm{O}_{5}\right)$ e $45 \mathrm{~g}$ de cloreto de potássio $(60 \%$ de $\mathrm{K}_{2} \mathrm{O}$ ).

Apōs a adubação do sulco, foram abertas nele co vas com dimensões de aproximadamente $25 \mathrm{~cm} \times 25 \mathrm{~cm} \times 25 \mathrm{~cm}$.

- espaçamento entre covas, nas duas êpocas de se meadura, foi de $0,70 \mathrm{~m}$ nas 1 inhas e $1,20 \mathrm{~m}$ entre 1 inhas. 


\section{$3 \cdot 3 \cdot 3$. Semeadura}

As sementes utilizadas nas duas êpocas de semeadu ra pertenciam a lotes que, em teste feito em 1970 pela Seção de Botânica do Instituto Agronômico do Estado de São Paulo, apre sentaram porcentagem de germinação superior a $85 \%$. Essas se mentes foram obtidas nos seguintes locais e épocas:

- cultivar Marketer: sementes de frutos perfeitos colhidos na Estação Experimental de Tietê do Instituto Agronômi co do Estado de São Paulo em 19 de dezembro de 1967;

- cultivar Palomar: sementes de frutos perfeitos colhidos na Estação Experimental de Monte Alegre do Sul do Ins tituto Agronômico do Estado de São Paulo em 19 de dezembro de 1967 ;

- cultivar Santee: mistura de sementes de frutos perfeitos colhidos na Estação Experimental de Monte Alegre do Sul entre 30 de novembro e 21 de dezembro de 1965, de sementes de frutos não selecionados colhidos no Centro Experimental de Campinas entre 22 de janeiro e 13 de fevereiro de 1969, e semen tes de frutos perfeitos colhidos na Estação Experimental de Mon te Alegre do Sul do Instituto Agronômico do Estado de São Pau 1o nos anos de 1963 e 1965 .

- cultivar Verde Paulistano: mistura de sementes de frutos não selecionados colhidos em diversas Estações Experi mentais do Instituto Agronômico do Estado de São Paulo entre os anos de 1968 e 1969 ;

- cultivar Aodai: sementes obtidas na Cooperativa Agrî́cola de Cotia em 1970 .

As sementes em todas as cultivares foram tratadas com Arasan 75 (75\% de Thiran ou bissulfeto de tetrametil Thi u ram), na proporção de $0,02 \mathrm{~g}$ para $400 \mathrm{~g}$ de sementes, para con trole de "damping-off", baseando-se em resultados obtidos por DEMATTE et alii (1970). 
Foram colocadas 5 sementes por cova, cobertas com uma camada de aproximadamente $2 \mathrm{~cm}$ de espessura de terra.

\subsubsection{Desbastes}

Nas duas êpocas de semeadura, o primeiro desbas te foi feito dez dias após a emergência das plântulas, deixan do duas plantas por cova, e o segundo, vinte e cinco dias após a emergência das plântulas, deixando uma planta por cova •

No desbaste, adotou-se o critério de retirar as plantas menos vigorosas.

\subsubsection{Condução das plantas}

Nas duas êpocas de semeadura, as plantas foram conduzidas em estacas de bambu com segmentos de ramificações dispostas verticalmente, ao lado de cada planta. Essas estacas foram colocadas nas covas por ocasião do segundo desbaste.

\subsubsection{Adubações em cobertura}

Por ocasião do segundo desbaste e vinte dias mais tarde, foram feitas, nas duas épocas de semeadura, aduba ções em cobertura, colocando-se $10 \mathrm{~g}$ de sulfato de amônio (20\% de $N$ ) por cova.

\subsubsection{Tratamento fitossanitärio}

Nas duas êpocas de semeadura, foram feitas pul verizações preventivas com Dithane z-78 (maneb + zinco ou etile no bis-ditiocarbamato de manganês + sulfato de zinco) na propor ção de $20 \mathrm{~g}$ para 10 litros de ägúa, Phosdrin (Mevinphos ou d $\frac{\mathbf{i}}{3}$ metil 2-carbometil-1-metilvinil fosfato) na proporção de $10 \mathrm{~cm}^{\overline{3}}$ para 10 litros de ägua, Malatol 50-E (Malathion ou 0,0-dimetil- 
-ditiofosfato-dietil-mercaptossuccinatol na proporção de $20 \mathrm{~cm}^{3}$ para 10 litros a eagua, Benlate [Benomil ou metil 1 (butil-car bomi1)-2-benzimidazole-carbamato) na proporção de $7 \mathrm{~g}$ para 10 litros de ägua. Utilizou-se espalhante adesivo comercial (Esa pon) misturado aos defensivos, na proporção de $2 \mathrm{~cm}^{3}$ para 10 litros de ägua.

As pulverizações com Dithane e Phosdrin ou Mala tol foram feitas semanalmente, desde o início da emergência das plântulas até o início do florescimento; Phosdrin e Malatol fo ram aplicados alternadamente. As pulverizações com Benlate fo ram feitas a cada quinze dias, desde o início da emergência das plântulas atê o início do florescimento.

\subsubsection{Irrigação}

A cultura, nas duas êpocas, foi irrigada pelo sistema de aspersão, que apresenta bons resultados para a cultu ra de pepino, conforme demonstraram trabalhos de DEMATTE et alii (1974).

Foram adicionados aproximadamente $10 \mathrm{~mm}$ de água a cada 2 dias, valores esses normalmente utilizados na irrigação da maioria das hortaliças cultivadas no local.

\subsubsection{Cultivo}

o controle de ervas daninhas foi feito com auxi lio de enxada.

\subsubsection{Colheitas}

Os frutos foram colhidos no ponto de consumo, is to $\vec{e}$, quando se apresentavam com aproximadamente $17 \mathrm{~cm}$ de com primento, tenros e com casca verde. 
Foram feitas 12 colheitas para a primeira êpoca de semeadura e 10 colheitas para a segunda época; entre cada colheita, observou-se o intervalo de 2 a 4 dias, conforme reco mendaram WHITAKER e DAVIS (1962).

\subsection{Delineamento estatístico}

0 experimento constou de dois ensaios de campo, instalados em duas êpocas de semeadura, em blocos casualizados, com 5 tratamentos e 5 repetições. Os tratamentos foram repre sentados pelas cultivares Marketer, Palomar, Santee, Verde Pau 1istano e Aodai.

A parcela constituiu-se de 72 plantas, distribuí das em 6 linhas, sendo 40 plantas üteis e 32 consideradas como bordadura.

\subsection{Características estudadas na cultura}

Foram estudadas neste experimento as caracterís ticas especificadas a seguir, para as cinco cultivares de pepí no nas duas êpocas de semeadura.

3.5.1. Início de germinação das sementes

3.5.2. Início de floração das plantas

3.5.2.1. Localização das primeiras flores masculinas e femininas

3.5.2.2. Nümero de dias decorridos desde a emergência das plântulas até o apa recimento da primeira flor masculina e da primeira flor feminina.

3.5.3. Nûmero de dias decorridos des de a emergência das plântulas até a primeira colheita; 
3,5.4. Características biomëtricas das plantas por ocasiâo do inficio das colheitas

$3,5,4,1$. Comprimento mêdio do ramo principal 3.5.4.2. Mëdia do nümero de ramificações late rais

3.5.5. Produção de frutos em nümero e peso

3.5.5.1. Total por colheita

3.5.5,2. Total de todas as colheitas

3.5.5.3. Comerciâvel por colheita (consideram -se comerciảveis os frutos sem defor mações e sem danificações).

3.5.5.4. Comerciāvel de todas as colheitas

3.5.5.5. Relação entre a produção comerciável e a produção total de todas as co 1heitas .

3.5.5.6. Peso médio dos frutos em relação à produção total de todas as colheitas

3.5.5.7. Peso mẻdio dos frutos em relação à produção comerciável de todas as co 1heitas

3.5.6. Correlações entre características estudadas

3.5.6.1. Produção total em peso por colheita $X$ numero total de frutos por colheita

3.5.6.2. Produção total em peso por colheita $X$ produção comerciâvel em peso. por colheita

3.5.6.3. Produção total em peso por colheita $X$ numero de frutos comerciäveis por colheita

3.5.6.4. Produção total de todas as colheitas $X$ produção total por colheita

3,5.6.5. Produção total de todas as colheitas $X$ número de dias decorridos desde a emergência das plântulas até a pri meira colheita. 
3.5:6.6. Produção total de todas as colheitas $X$ comprimento médio do ramo princi pal das plantas na êpoca do inîcio das colheitas

3,5.6.7. Produção total de todas as colheitas $X$ mêdia do nümero de ramificações $1 \underline{a}$ terais das plantas na êpoca do iní cio das colheitas

3.5.6.8. Produção total de todas as colheitas $X$ peso médio do fruto em relação à produção total

3.5.6.9. Produção total de todas as colheitas $X$ peso médio do fruto em relação à produção comerciảvel

3.5.6.10. Idade da planta X produção por co 1heita

3.5.6.11. Idade da planta $X$ relação entre pro dução comerciävel em peso por colhei ta e produção total em peso por co 1heita

3.5.6.12. Idade da planta $X$ peso mëdio do fru to em relação à produção total

3.5.6.13. Idade da planta $x$ peso médio do fru to em relação à produção comerciảvel

3.6. Análise estatística dos dados

Entre as características especificadas no îtem 3.5., foram analisados estatisticamente os dados daquelas refe rentes aos îtens 3.5.3., 3.5.4., 3.5.5. e 3.5.6.

A comparação entre as médias dos dados referentes às caradterîsticas especificadas nos ítens 3.5.3., 3.5.4. e 3.5.5. foi feita pela anảlise da variância, aplicando-se os testes $F$ e de Tukey, ao nível de 5\% de probabilidade. Os dados 
representados por numeros inteiros foram transformados em $\sqrt{x}$.

A comparação dos resultados obtidos nas duas êpo cas de semeadura ou dos dados obtidos em diversas colheitas foi feita por anảlise conjunta de experimentos, sempre que o quoci ente entre o maior e o menor quadrados mêdios das diversas anáa lises de variância consideradas para anâlise conjunta não exce dia 4 unidades. Na anâlise conjunta dos resultados obtidos em diversas colheitas, os dados foram transformados en $\sqrt{x}+0,5$ por haver parcelas em que a produção era igual a zero.

As correlações especificadas no item 3.5.6. fo ram calculadas atravês da determinação do coeficiente de corre lação ( $r$ ) entre as duas variảveis e a da sua transformação no valor $t$, com o fiun de proceder-se à comparação com valores da tabela apresentada por PIMENTEL GOMES (1963) para verificação de significância.

Quando se tratava de correlação em que uma das variâveis consideradas era peso mẻdio de frutos, aplicou-se för mula modificada que leva em conta o numero de frutos cujo peso médio foi calculado. Esta förmula baseia-se em förmula apresen tada por HOFFMANN e VIEIRA (1977) e é a seguinte:

$$
r=\frac{\Sigma x_{i} y_{i} f_{i}-\frac{I^{\Sigma}=1 \quad f_{i} \Sigma y_{i} f_{i}}{\Sigma f_{i}}}{\sqrt{\left[\sum x_{i}^{2} f_{i}-\frac{\left(\Sigma x_{i} f_{i}\right)^{2}}{f_{i}}\right]\left[y_{i} f_{i}-\frac{\left(\Sigma y_{i} f_{i}\right)^{2}}{f_{i}}\right]}}
$$

onde:

$$
\begin{aligned}
& x_{i}=\text { idade da planta; } \\
& y_{i}=\text { peso mêdio dos frutos } \\
& f_{i}=\text { numero de frutos cujo peso mêdio é } y_{i} .
\end{aligned}
$$


4. RESULTADOS

Os resultados obtidos no presente estudo são apre sentados a seguir.

\subsection{Considerações gerais.}

4.1.1. Primeira época de semeadura ( 5 de maio de 1970)

O inîcio de germinação das sementes de todas as cultivares ocorreu em 11 de maio de 1970.

Na Tabela 3, são indieadas as posiçós em que se abriram as primeiras flores masculinas e femininas das plantas das cultivares estudadas e, na Tabela 4, apresenta-se 0 número de dias decorridos desde a emergêncta das plântulas a té a aber tura da primeira flor masculina e da primeira flor feminina.

Aproximadamente 35 dias apôs a emergêncìa das plântulás, observaram-se no campo sintomas de virose: enrugamen to das folhas de algumas plantas e atraso no desenvolvimento 
dessas plantas. 0 ataque de virose intensificou-se, chegando a prejudicar a produçẫo das plantas afetadas, que produziram a1 guns frutos deformados e com manchas de coloração verde-claro , (Figura 1).

Foram observadas lesôes necróticas nas folhas de algumas plantas de todas as cultivares, aproximadamente 80 dias apỏs sua emergência. Pelo exame microscópico feito pela Seção de Fitopatologia do Instituto Agronômico do Estado de São Paulo, constatou-se que as folhas lesadas estavam atacadas de míldio (Pseudoperonospora cubensis (Berk. \& Curt.) Rostow.) Esse ataque nẫo chegou a prejudicar a produção das plantas.

4.1.2. Segunda época de semeadura ( 5 de dezembro de 1970 )

0 inîcio de germinação das sementes de todas as cultivares ocorreu em 9 de dezembro de 1970 .

$\mathrm{Na}$ Tabela 5 , são indicadas as posições em que se abriram as primeiras flores masculinas e femininas das plantas das cultivares estudadas, e, na Tabela 6 , apresenta-se o número de dias decorridos desde a emergência das plântulas até a aber tura da primeira flor masculina e da primeira flor feminina.

Do mesmo modo que na primeira época de semeadura, observou-se ataque de míldio em algumas plantas de todas as cul tivares (Figura 2). Desta vez, o ataque iniciou-se aproximadamente 30 dias após a emergência das plântulas e foi mais inten so que o ocorrido na primeira época.

A partir da terceira atê a Ultima colheita, gran de porcentagem dos frutos de todas as cultivares apresentou-se atacada de broca (Margaronia sp.). Os frutos mais atacados fo ram os de Verde Paulistano (Figura 3). 
4,2. Anâlise estatîstica de dados obtidos

4.2.1. Prìmeìra êpoca de semeadura (5 de maío de 1970)

A Tabela 7 apresenta as médias dos dados referen tes a diversos parâmetros, bem como os respectivos valores obti dos pelo teste $F$, pelo cấlculo do coeficiente de variação (C.V. :) e pelo câlculo da diferença mînima significativa atravês do teste de Tukey ao nível de 5: de probabilidade (d.m.s.).

A Tabela 8 apresenta as médias de produção total em peso de frutos das cinco cultivares, obtidas em cada colheita, e os respectivos valores de $F$, do coeficiente de variação e da diferença mînima significativa a $5 \%$ de probabilidade.

Na Tabela 9, encontram-se as mêdias referentes a dados de produção de todas as colheitas e os respectivos valo res de $\mathrm{F}$, do coefịciente de variação e da diferença mínima sig nificativa a $5 \%$ de probabilidade.

0 coeficiente de correlação $(r)$ e os respectivos valores de $t$ entre diversas variâveìs são apresentadas na Tabe 1a 10 .

4.2.2. Segunda época de semeadura (5 de dezembro de 1970)

A Tabela 11 apresenta as mêdias dos dados referen tes a diversos parâmetros e os respectivos valores de F, do coeficiente de variação e da diferença mínima-significativa a $5 \%$ de probabilidade.

As Tabelas 12 e 13 apresentam, respectivamente, as mêdias das produçôes totais em peso e em nûmero de frutos das cinco cultivares, obtidas em cada colheita, e os respecti vos valores de $F$, do coeficiente de variação e da diferença mí nima significativa a $5 \%$ de probabilidade.

Na Tabela 14, encontram-se as médias referentes a dados de produção de todas as colheitas e os respectivos valo 
- res de $F$, do coeficiente de variação e da diferença mínima sig nificativa a $5 \%$ de probabilidade.

Os coeficientes de correlação $(r)$ e os respec tivos valores de $t$ entre diversas variâveis são apresentadas na Tabela 15 .

\subsubsection{Consideraçôes referentes às duas êpocas de semeadura}

As comparações entre as mêdias de dados obtidos na primeira e segunda êpocas de semeadura, feitas por análise conjunta de experimentos, nos casos em que o quociente entre os respectivos quadrados médios não excedeu 4 unidades, encon tram-se na Tabela 16.

As comparações das mêdias de produção por colhei ta apresentadas nas Tabelas 8,10 e 13 mostram que, na primei ra êpoca de semeadura, as produções mâximas foram atingidas na quarta, quinta e dêcima colheitas e, na segunda época, a produ ção mäxima concentrou-se na metade do período de colheitas. A Figura 4 relaciona a produção média de frutos das cinco cultí vares com a idade da planta, nas duas êpocas de semeadura.

A Figura 5 ilustra a diferença de comportamento das cultivares em relação à êpoca de semeadura.

Pela observação das Tabelas $8,18,12,13$ e 14 e da Figura 5, verifica-se que as cultivares Palomar e Verde Pau listano foram favorecidas pela semeadura em maio, enquanto Ao dai foi favorecida pela semeadura em dezembro.

As correlaçőes positivas significativas encontra das, nas duas êpocas, entre a produção total em peso por có Theita e o número total de frutos por colheita, a produção co merciâvel por colheita e o número de frutos comerciáveis por colheita, e entre o número total de frutos por colheita e a produção comerciável em nưmero e peso de frutos (Tabelas 10 e 15) indicam que resultados de anâlises estatísticas feitas pa ra uma dessas variáveis são válidos para as outras variāveis que com ela se correlacionam. 
Do mesmo modo, se os pesos mêdios do fruto em relaçẫo à produçẫo total e à produção comerciâvel sâo positti vamente correlacionados (Tabela 15), o peso médio do fruto em relação à produção comerciẩvel tambêm estâ correlacionado nega tivamente com a idade da planta, assim como o peso mêdio do fruto em relação à produção total.

Fotografias de amostras de frutos das cinco cul tivares nas diversas colheitas das duas êpocas de semeadura são apresentadas a partir da Figura 6 . 
, Tabela 3. Localização das primeiras flores masculinas e femi ninas de cultivares de pepino semeadas em 5 de maio de 1970 no Centro Experimental de Campinas, em Cam pinas, SP.

\begin{tabular}{lcccc}
\hline \multirow{2}{*}{ Cultivares } & \multicolumn{2}{c}{ Localização das primeiras flores (nö) } \\
\cline { 2 - 3 } & \multicolumn{2}{c}{ Masculinas } & & \multicolumn{2}{c}{ Femininas } \\
\cline { 2 - 3 } \cline { 4 - 5 } ramo principal & & ramo principal $1^{\circ}$ ramo secundário \\
Marketer & $1^{\circ}$ e $2^{\circ}$ & & $4^{\circ}, 6^{\circ}$ e $7^{\circ}$ & - \\
Palomar & $1^{\circ}$ e $2^{\circ}$ & & $6^{\circ}$ e $7^{\circ}$ & $2^{\circ}$ \\
Santee & $1^{\circ}$ e $2^{\circ}$ & & - & $2^{\circ}$ \\
Verde Paulistano & $2^{\circ}$ e $3^{\circ}$ & & $8^{\circ}$ e $9^{\circ}$ & - \\
Aodai & $1^{\circ}, 2^{\circ}$ e $3^{\circ}$ & $5^{\circ}$ e $6^{\circ}$ & - \\
\hline
\end{tabular}


-Tabela 4. Nümero de dias decorridos desde a emergência das plântulas até a abertura das primeiras flores mascu linas e femininas de cultivares de pepino semeadas em 5 de maio de 1970 no Centro Experimental de Cam pinas, em Campinas, SP.

Cultivares

Nümero de dias decorridos desde a emergên cia das plântulas até a abertura da prî meira flor

Masculina

Feminina

Marketer

Palomar

Santee

Verde Paulistano.

Aodai 
Tabela 5. Localização das primeiras flores masculinas e femi ninas de cultivares de pepino semeadas em 5 de de zembro de 1970 no Centro Experimental de Campinas, em Campinas, SP.

\begin{tabular}{|c|c|c|c|c|c|}
\hline \multirow{3}{*}{ Cultivares } & \multicolumn{5}{|c|}{ rimeiras flores (nó) } \\
\hline & \multirow{2}{*}{ 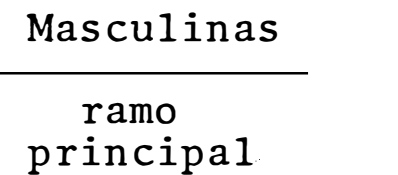 } & \multicolumn{4}{|c|}{ Femininas } \\
\hline & & $\begin{array}{c}\text { ramo } \\
\text { principal }\end{array}$ & $\underset{18}{\operatorname{ramos}}$ & $\begin{array}{l}\text { secum } \\
2^{8}\end{array}$ & ios \\
\hline Marketer & 28 e 38 & 38 & 18 & 18 & - \\
\hline Palomar & $2^{\circ}$ e $3^{\circ}$ & - & $1^{\circ}$ e $2^{\circ}$ & - & - \\
\hline Santee & 28 e 38 & - & $3^{\circ}$ & - & - \\
\hline Verde Paulistano & 38 e 48 & - & - & 18 & $1 \%$ \\
\hline Aodai & $2^{\circ}, 3^{\circ}$ e $4^{\circ}$ & - & 18 e $3 \%$ & - & - \\
\hline
\end{tabular}


- Tabela 6. Nûmero de dias decorridos desde a emergência das plântulas atê a abertura das primeiras flores mascu linas e femininas de cultivares de pepino semeadas em 5 de dezembro de 1970 no Centro Experimental de Campinas, em Campinas, SP.

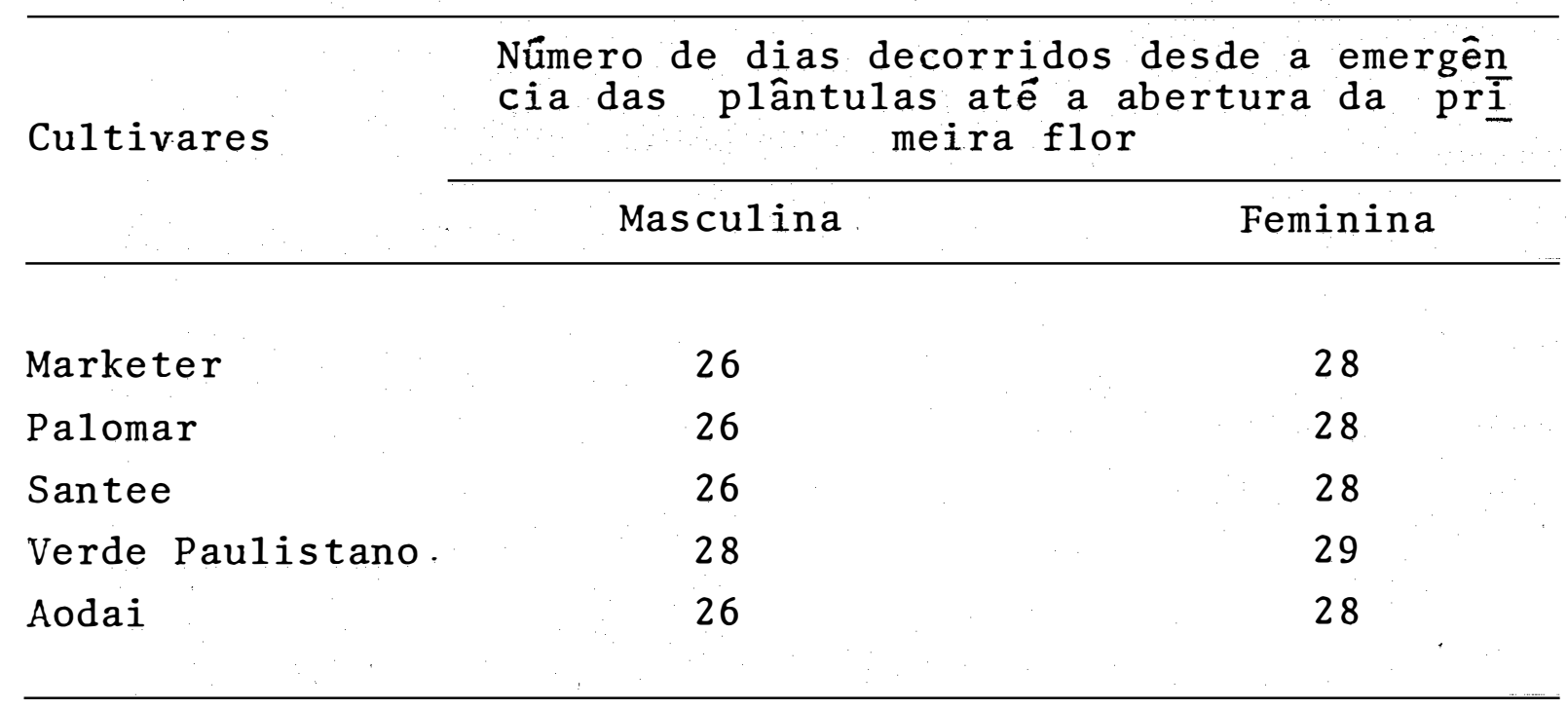


Tabela 7. Médias do número de dias decorridos desde a emergên cìa das plântulas até a primeìra colheita, comprimen to do ramo principal e número de ramos laterais das plantas em 7 de julho de 1970 , em cultivares de pepi no semeadas em 5 de maio de 1970 no Centro Experi mental de Campinas, em Campinas, SP. a/

\begin{tabular}{|c|c|c|c|}
\hline Cultivares & $\begin{array}{l}\text { Média do número de } \\
\text { dias decorridos des } \\
\text { de a emergência das } \\
\text { plântulas atê a prí } \\
\text { meira colheita } \\
\qquad(\sqrt{\mathrm{x}})\end{array}$ & $\begin{array}{l}\text { Comprimento mé } \\
\text { dio do ramo } \\
\text { principal } \\
\text { (cm) }\end{array}$ & $\begin{array}{l}\text { Mëdia do núme } \\
\text { ro de ramos } \\
\text { laterais }\end{array}$ \\
\hline Marketer & $7,59 \quad b$ & $165,14 \quad b$ & $4,21 \mathrm{ab}$ \\
\hline Palomar & $7,55 \quad b$ & $135,72 \quad b$ & $4,26 \mathrm{ab}$ \\
\hline Santee & $7,59 \quad b$ & $116,05 \quad \mathrm{c}$ & $2,87 \quad b$ \\
\hline Verde Paulistano & 7,82 a & 227,74 a & 4,72 a \\
\hline Aodai & $7,63 \mathrm{ab}$ & 219,98 a & 5,20 a \\
\hline $\mathrm{F}$ & $6,00^{* * \mathrm{~b} /}$ & $162,26^{* * b /}$ & $6,67^{* * \text { b } /}$ \\
\hline C.V. $\left(\frac{\%}{0}\right)$ & 1,31 & 5,05 & 17,65 \\
\hline d.m.s. $(5 \%)$ & 0,19 & 16,94 & 1,45 \\
\hline
\end{tabular}

a/ = mêdias acompanhadas da mesma letra não diferem entre si;

$\underline{\mathrm{b}} /$ = significativo ao nível de $1 \%$ de probabilidade. 
'0

ช'

守

$\begin{array}{ll}\text { n } & 0 \\ 0 & 0 \\ 0 & 0 \\ +1 & 0 \\ 0 & 0\end{array}$

\begin{tabular}{cc}
0 & 0 \\
0 & 0 \\
+3 & 0 \\
\hline & 0 \\
4 & 0 \\
\hline 1 & 0
\end{tabular}

잉

in n

ڤ

ฉ

E

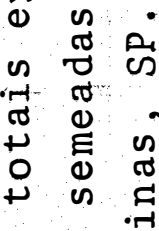

\&

to.

光

0 o

ถุ

on is o

రृ

( )

๘

नु

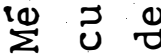

$\infty$

赵
4

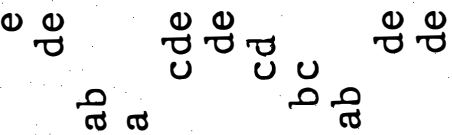

- 9 Q

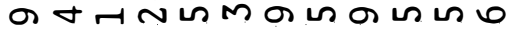

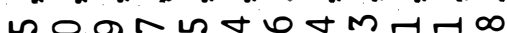

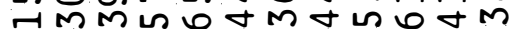

.

(7)

$\forall N \forall$ MNOMMOII GOनOGONMAMMN ने न
0

n

崩

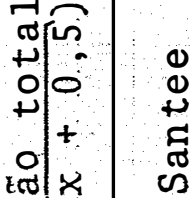

บ

चे

우

a

ه

o

त्र

गु

$\stackrel{10}{\Sigma}$

我
$M+\pi N-10-\infty+N N 0$

임

c.

$\stackrel{0}{5}$

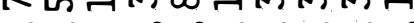

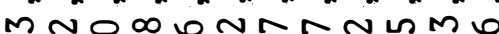
न

Di

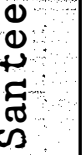

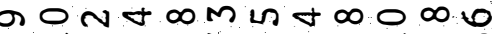
I nT HMnOOOAOMn तNM $\forall$ NMM $\forall$ Mm

MONATHOt mona 0 开 Noññ

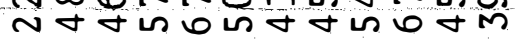

$+$

$0+\infty \circ \cup \infty-\forall+\infty \circ \infty$

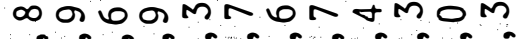

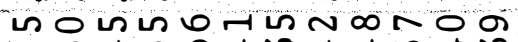

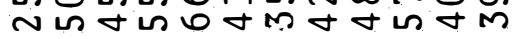
$\sum^{\infty}$

త్ర జ્త

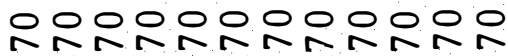

జ

+ न

串

ร • . . ర

U.

- ठ

o + t

०. . च क्ष

+

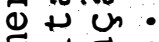

E.

+20 in in

क्र०

† 0.7 . .

(1) en en

$\pi$.

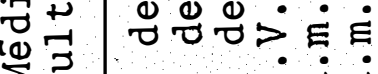

का व

E

00

$\pi-1$

రृ

कान

की

ठृ

ट

贾:

ơ

0

II I Uण ठ 


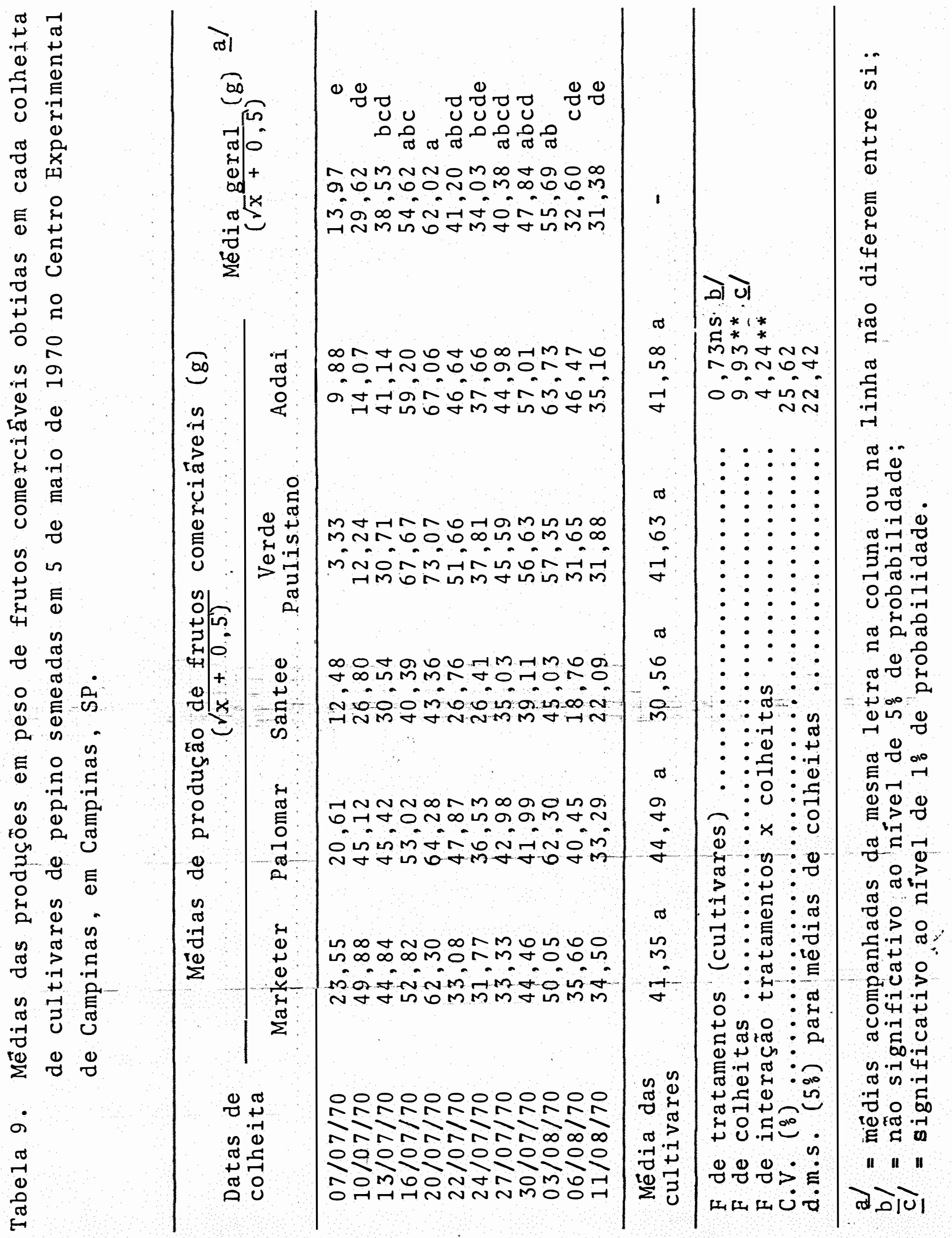


-Tabela 10, Coeficientes de correlaçôes $(r)$ e respectivos valo res de $t$ entre diversas variâveis ( $X$ e $Y$ ) relativas às cultivares de pepino Marketer, Palomar, Santee, Verde Paulistano e Aodai, semeadas em 5 de maio de 1970 no Centro Experimental de Campinas, em Campi nas, SP.

\begin{tabular}{|c|c|c|c|}
\hline$X$ & $Y$. & $r$ & $t$ \\
\hline $\begin{array}{l}\text { produção total em peso } \\
\text { por colheita }\end{array}$ & $\begin{array}{l}\text { número total de frutos } \\
\text { por colheita }\end{array}$ & 0,95 & $54,64^{* * a /}$ \\
\hline $\begin{array}{l}\text { produção total em peso } \\
\text { por colheita }\end{array}$ & $\begin{array}{l}\text { nümero comerciâvel em } \\
\text { peso por colheita }\end{array}$ & 0,97 & $76,10^{\star *}$ \\
\hline $\begin{array}{l}\text { produção total em peso } \\
\text { por colheita }\end{array}$ & $\begin{array}{l}\text { número de frutos comer } \\
\text { ciâveis por colheita }\end{array}$ & 0,96 & $59,17^{\star \star}$ \\
\hline $\begin{array}{l}\text { produção total em peso } \\
\text { de todas as colheitas }\end{array}$ & $\begin{array}{l}\text { produção total em peso } \\
\text { da primeira colheita }\end{array}$ & $-0,12$ & $-0,59^{\mathrm{ns}} \underline{\mathrm{b}}$ \\
\hline $\begin{array}{l}\text { produção total em peso } \\
\text { de todas as colheitas }\end{array}$ & $\begin{array}{l}\text { produção total em peso } \\
\text { da segunda colheita }\end{array}$ & 0,38 & $1,96^{\mathrm{nS}}$ \\
\hline $\begin{array}{l}\text { produção total em peso } \\
\text { de todas as colheitas }\end{array}$ & $\begin{array}{l}\text { produção total em peso } \\
\text { da terceira colheita }\end{array}$ & 0,74 & $5,30^{* *}$ \\
\hline $\begin{array}{l}\text { produção total em peso } \\
\text { de todas as colheitas }\end{array}$ & $\begin{array}{l}\text { produção total em peso } \\
\text { da quarta colheita }\end{array}$ & 0,85 & $7,70^{* *}$ \\
\hline $\begin{array}{l}\text { produção total em peso } \\
\text { de todas as colheitas }\end{array}$ & $\begin{array}{l}\text { produção total em peso } \\
\text { da quinta colheita }\end{array}$ & 0,87 & $8,52^{* *}$ \\
\hline $\begin{array}{l}\text { produção total em peso } \\
\text { de todas as colheitas }\end{array}$ & $\begin{array}{l}\text { produção total em peso } \\
\text { da sexta colheita }\end{array}$ & 0,64 & $3,99^{* *}$ \\
\hline $\begin{array}{l}\text { produção total em peso } \\
\text { de todas as colheitas }\end{array}$ & $\begin{array}{l}\text { produção total em peso } \\
\text { da sêtima colheita }\end{array}$ & 0,82 & $6,90^{* *}$ \\
\hline $\begin{array}{l}\text { produção total em peso } \\
\text { de todas as colheitas }\end{array}$ & $\begin{array}{l}\text { produção total em peso } \\
\text { da oitava colheita }\end{array}$ & 0,80 & $6,40^{* *}$ \\
\hline $\begin{array}{l}\text { produção total em peso } \\
\text { de todas as colheitas }\end{array}$ & $\begin{array}{l}\text { produção total em peso } \\
\text { da nona colheita }\end{array}$ & 0,84 & $7,47^{* *}$ \\
\hline
\end{tabular}


Tabela 10, (Continuação)

produção total em peso
de todas as colheitas
produção total em peso
de todas as colheitas
produção total em peso
de todas as colheitas

produção total em peso de todas as colheitas

produção total em peso de todas as colheitas

produção total em peso de todas as colheitas

produção total em peso de todas as colheitas

produção total em peso de todas as colheitas

idade da planta

idade da planta

\section{$Y$}

produção total em peso da dêcima colheita

produção total em peso da dêcima primeira co 1heita

produção total em peso da décima segunda co Theita

número de dias decorri dos desde a emergência das plântulas atê a primeira colheita

comprimento médio do ramo principal das plan tas na época do início das colheitas

média do número de ra mi ficações laterais das plantas na época do início das colheitas

peso médio do fruto em relação à produção to tal

peso médio do fruto em relaçãa à produçẫo co merciâve1

produção total em peso por colheita

produção comerciâve1 em peso por colheita t.

11,32

0,92

0,79

$6,12^{* *}$

0,72

$5,01^{* *}$

0,92

$11,04^{* *}$

0,51

$2,85^{*}$

0,66

$4,22^{* *}$ o (n)

$0,46 \quad 2,48^{*} \underline{\mathrm{b}} \mathrm{y}$

$0,41 \quad 2,16^{*}$

$0,20 \quad 1,56^{\mathrm{ns}} \mathrm{c}$

$0,07 \quad 0,53^{\text {ns }}$

\footnotetext{
$\underline{a} /$ significativo a nóvel de $1 \%$ de probabilidade; $\underline{b} /=$ significativo ao nível de $5 \%$ de probabilidade; $\underline{c}$ l = não significativo ao nîvel de 5\% de probibilidade.
} 
Tabela 10. (Continuaçẫo)

\begin{tabular}{|c|c|c|c|}
\hline$\ldots X \mathrm{X}$ & $Y$ & $r$ & $t$ \\
\hline İdade da planta & $\begin{array}{l}\text { relação entre produção } \\
\text { comerciâuel em peso por } \\
\text { colheita e produção to } \\
\text { tal em peso por colheî } \\
\text { ta }\end{array}$ & $-0,51$ & $-4,52^{* *} \underline{a}$ \\
\hline idade da planta & $\begin{array}{l}\text { peso médio do fruto em } \\
\text { relaçẫo ầ produção to } \\
\text { tal }\end{array}$ & $-0,39$ & $-2,49^{* *}$ \\
\hline idade da planta & $\begin{array}{l}\text { peso médio do fruto em } \\
\text { relaçẫo à procução co } \\
\text { merciấvel }\end{array}$ & $-0,46$ & $-3,99^{* *}$ \\
\hline
\end{tabular}

a/ = significativo ao nível de $1 \%$ de probabilidade. 
-Tabela 11. Médias de nủmero de dias decorridos desde a emergên cìa das plântulas até a primeira colheita, comprimen to do ramo principal e número de ramos laterais das plantas em 20 de janeiro de 1971 , em cultivares de pepino semeadas em 5 de dezxubo de 1970 no Centro Expe rimental de Campinas, em Campinas, SP. a/

\begin{tabular}{|c|c|c|c|}
\hline Cultivares & $\begin{array}{l}\text { Média do número de } \\
\text { dias decorridos des } \\
\text { de a emergência das } \\
\text { plântulas até a pri } \\
\text { meira colheita } \\
(\sqrt{x})\end{array}$ & $\begin{array}{l}\text { Comprimento mé } \\
\text { dio do ramo } \\
\text { principal } \\
\text { (cm) }\end{array}$ & $\begin{array}{l}\text { Média do nưme } \\
\text { ro de ramos } \\
\text { laterais }\end{array}$ \\
\hline Marketer & 5,71 a & $211,74 \quad b$ & 12,20 a \\
\hline Palomar & $5,69 a$ & $184,50 \quad b$ & 10,69 a \\
\hline Santee & 5,69 a & $182,21 \quad b$ & 9,28 a \\
\hline Verde Paulistano & 5,72 a & 269,82 a & 11,18 a \\
\hline Aodai & $5,69 \mathrm{ab}$ & 259,75 a & 12,79 a \\
\hline $\mathrm{F}$ & $2,00^{\mathrm{ns}} \underline{\mathrm{b}} /$ & $20,52^{* *} \mathrm{c} /$ & $2,35^{\mathrm{ns}} \underline{\mathrm{b} /}$ \\
\hline C.V. $\left(\frac{0}{0}\right)$ & 6,15 & 9,19 & 17,72 \\
\hline d.m.s. $(5 \%)$ & - & 39,45 & - \\
\hline
\end{tabular}

a/ = médias acompanhadas da mesma letra não diferem entre si:

b/ = não significativo:ao nîvel de $5 \%$ de probabilidade;

$\underline{c}$ / = significativo ao nível de $1 \%$ de probabilidade. 


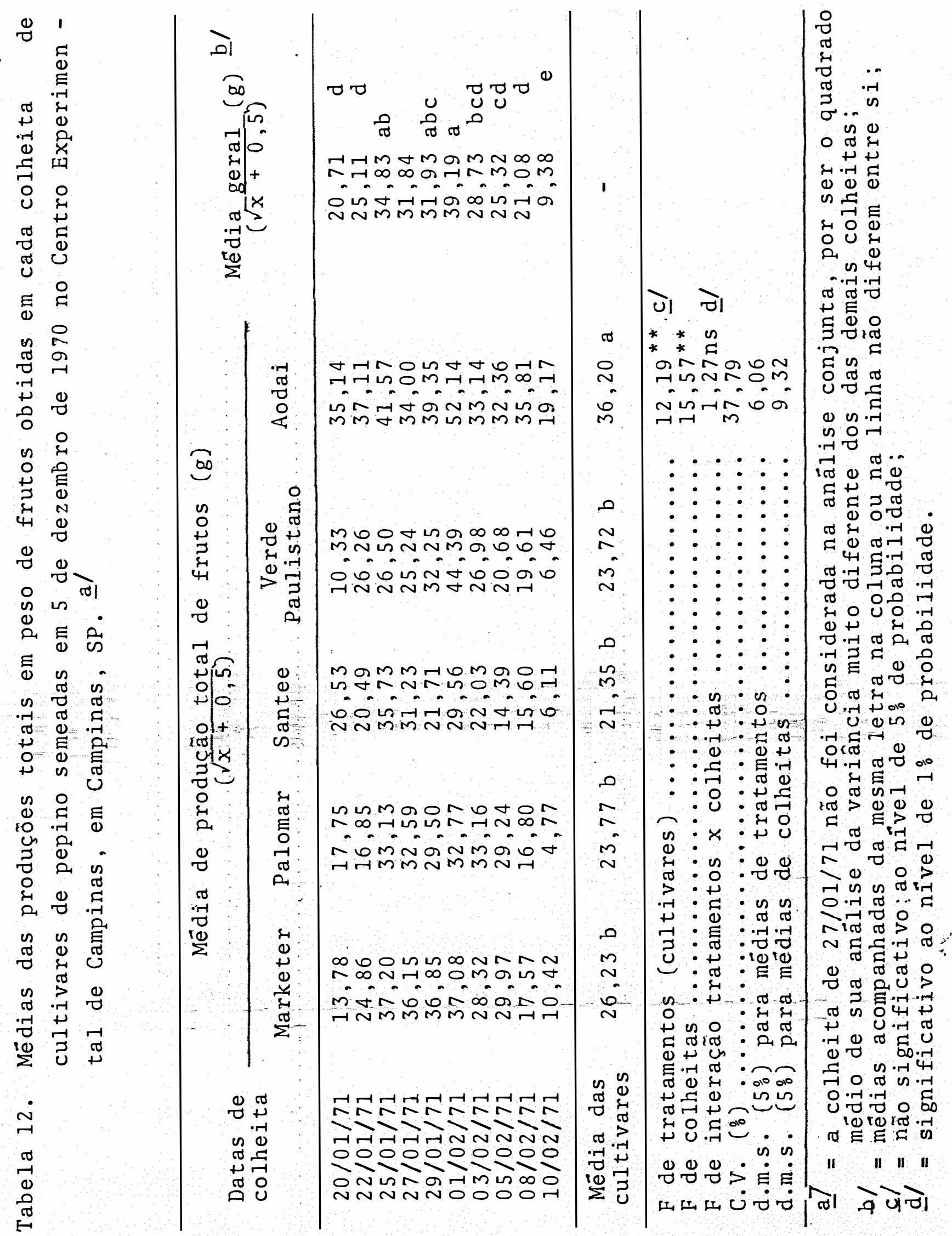




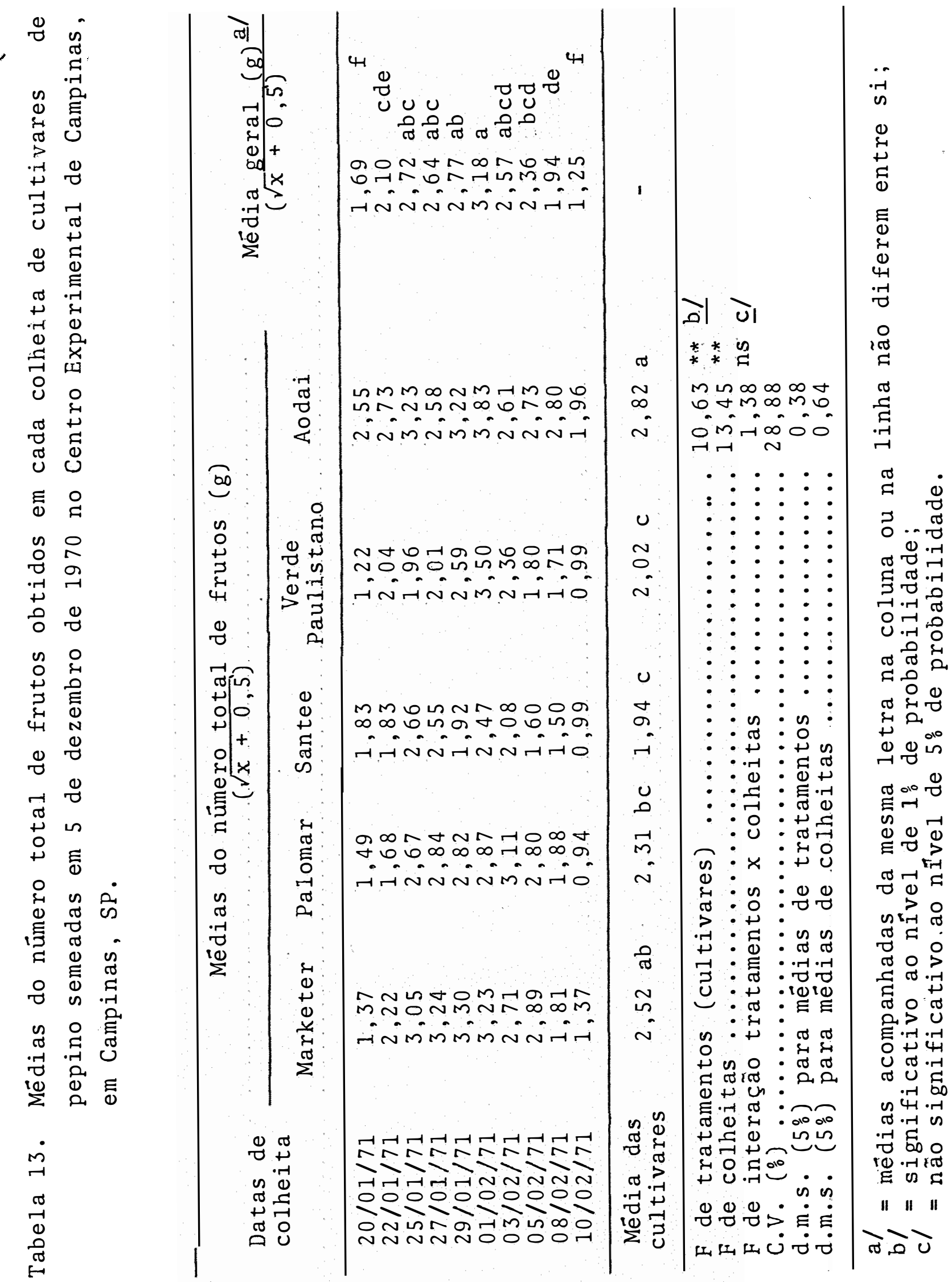




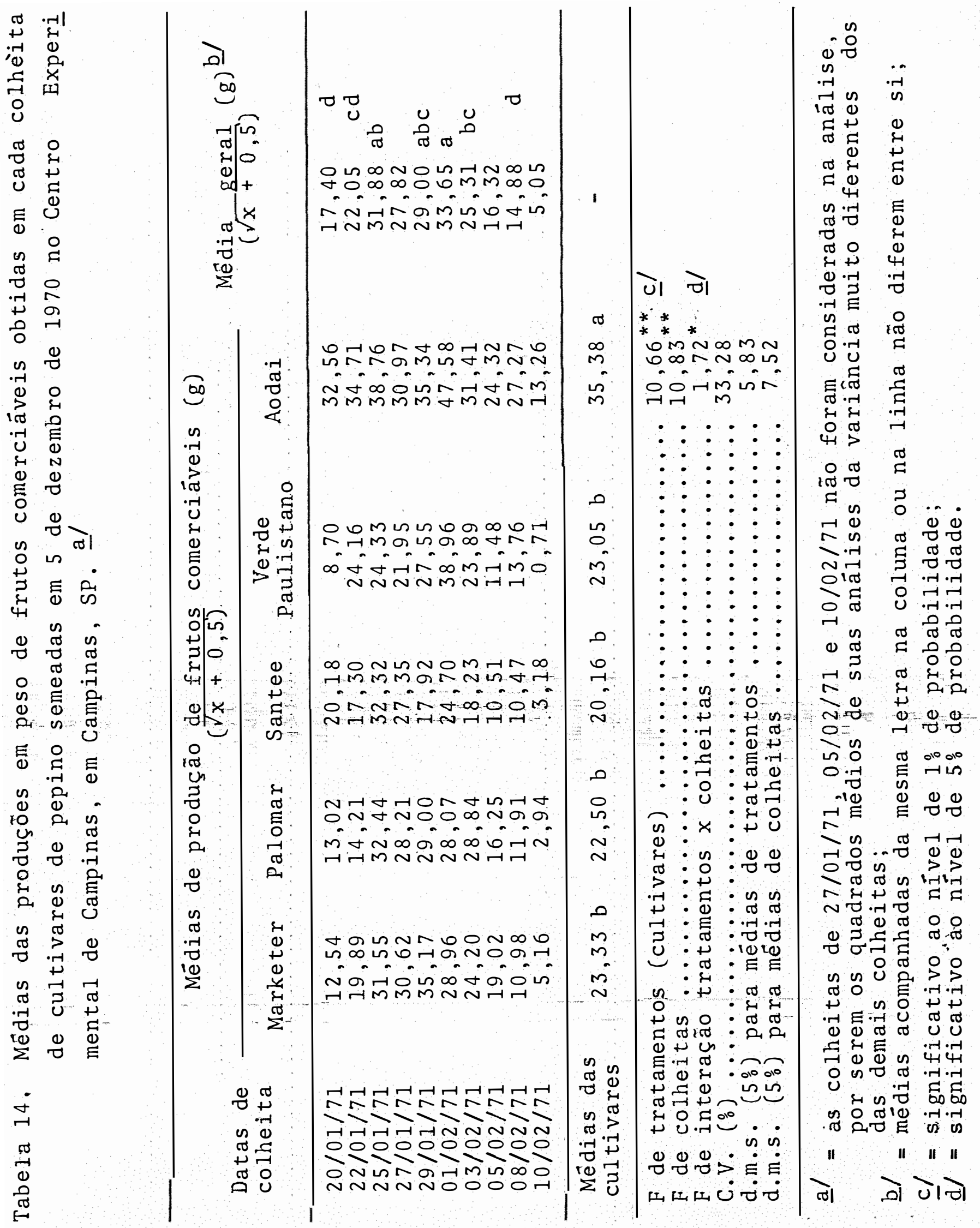


- Tabela 15, Coeficịentes de correlação (r) e respectivos valo res de $t$ entre diversas variâveis ( $\mathrm{X}$ e $\mathrm{X}^{\prime}$ ) relati vas às cultìvares de pepino Marketer, Palomar, San tee, Verde Paulistano e Aodai, semeadas em 5 de de zembro de 1970 no Centro Experimenta1 de Campinas em Campinas, SP.

\section{$\mathrm{X}$}

produção total em peso por colheita

nüjero total de frutos por colheita

núnero total de frutos por colheita

produção total em peso de todas as colheitas

produção total em peso de todas as colheitas

produção total em peso de todas as colheitas

produção total em peso de todas as colheitas

produção total em peso de todas as colheitas

produção total em peso de todas as colheitas

prodūção total em peso de todas as colheitas

produção total em peso de todas as colheitas.

produção total em peso de todas as collheitas

produção total em peso de todas as colleitas nứnero total de frutos por collheita

produçâo comerciáve1 em peso por colheita

número de frutos comer ciáveis por colheita

produção total em peso da primeira colheita

produção total em peso da segunda colheita

produção total em peso. da terceira colheita

produção total em peso da quarta colheita

produção total em peso da quinta colheita

produção total em peso da sexta colheita

prodūção total em peso da sêtima colheita

produção total em peso da oitava colheita

produção total em peso da nona colheita

produção total em peso da dêcima colheita $t$

\begin{tabular}{|c|c|}
\hline 0,96 & $48,86^{* *} \underline{a}$ \\
\hline 0,90 & $28,50^{* *}$ \\
\hline 0,96 & $48,86^{* *}$ \\
\hline 0,56 & $3,28^{* *}$ \\
\hline 0,63 & $3,93^{* *}$ \\
\hline 0,60 & $3,60^{* *}$ \\
\hline 0,18 & $0,88^{\mathrm{ns}} \underline{\mathrm{b}}$ \\
\hline 0,59 & $3,50^{* *}$ \\
\hline 0,79 & $6,22^{* *}$ \\
\hline 0,40 & $2,09^{* *}$ \\
\hline 0,49 & $2,71^{* *}$ \\
\hline 0,78 & $6,04^{* *}$ \\
\hline 0,70 & $4,73^{* *}$ \\
\hline
\end{tabular}

$\underline{a} /=$ significativo ao níve 1 de $1 \%$ de probabilidade;
$\underline{b} /=$ não significativo ao n 1 ive 1 de $5 \%$ de probabilidade. 
Tabela 15. (Continuaçã̃o) :

produção total em peso de todas as colheitas

produção total em peso de todas as colheitas

produção total em peso de todas as colheitas

produção total em peso de todas as colheitas

produção total em peso de todas as colheitas

idade da planta

idade da planta

idade da planta

idade da planta

idade da planta

peso médio do fruto em relação à produção to tal nựnero de dias decorridos desde a emergểncia das plầntulas atề a primeira colheita

comprimento médio do ramo principal na época do iní cio das colheitas

mêdia do nửmero de ramifi $0,24 \quad 1,19^{\text {ns }}$ cações laterais das plan= tas na época do inícìo das colheitas

peso médio do fruto em re $0,35 \quad 1,17^{\mathrm{nS}}$ lação à produção total

peso mëdio do fruto em re $0,34 \quad 1,74^{\text {ns }}$ lação à produçã̃o comercia â vel

produção total em peso $-0,20 \quad-1,41^{\text {ns }}$ por colheita

produção comerciâve1 em $-0,29-2,12^{*}$ b/ peso por colheita

relação entre produção co $\quad-0,61-5,36{ }^{* *} \underline{c}$ / merciâuel em peso por colheita e produção tọ tal em peso por colheita

peso mêdio do fruto em re $-0,45-3,51^{* *}$ lação ầ produção total

peso médio do fruto em re laçẫo à produção comerciē ve1

peso mêdio do fruto em re lação à produção comerciêa ve1

a/ = nẫo sígnificativo; a n nilvel de $5 \%$ de probabilidade;

b/ = significativo ao nîvel de $5 \%$ de probabilidade;

c/ = significativo ao nível de $1 \%$ de probabilidade. 
-Tabela 16. Comparações entre as mêdias de dados obtịdos para cultivares de pepino semeadas em 5 de maìo e 5 de dezembro de 1970 no Centro Experimental de Campinas em Campinas, SP.

\begin{tabular}{|c|c|c|c|}
\hline \multirow{2}{*}{$\begin{array}{l}\text { Datas de } \\
\text { semeadura }\end{array}$} & \multicolumn{2}{|c|}{ Nûmero de frutos $(\sqrt{x})$} & \multirow{2}{*}{$\begin{array}{l}\text { Relação entre a produção } \\
\text { comerciâvel em peso e } \\
\text { a produção total em peso }\end{array}$} \\
\hline & Total & comerciâveis & \\
\hline $05 / 05 / 77$ & 14,50 & 13,11 & 0,84 \\
\hline $05 / 12 / 70$ & 7,45 & 6,22 & 0,72 \\
\hline $\mathrm{F}$ & $118,56^{* *}$ a/ & $102,68^{* *} \cdot \mathrm{a} /$ & $30,00^{* * a /}$ \\
\hline C.V. $\left(\frac{o}{0}\right)$ & 13,76 & 14,06 & 5,13 \\
\hline
\end{tabular}

a/ = significativo ao nível de $1 \%$ de probabilidade. 


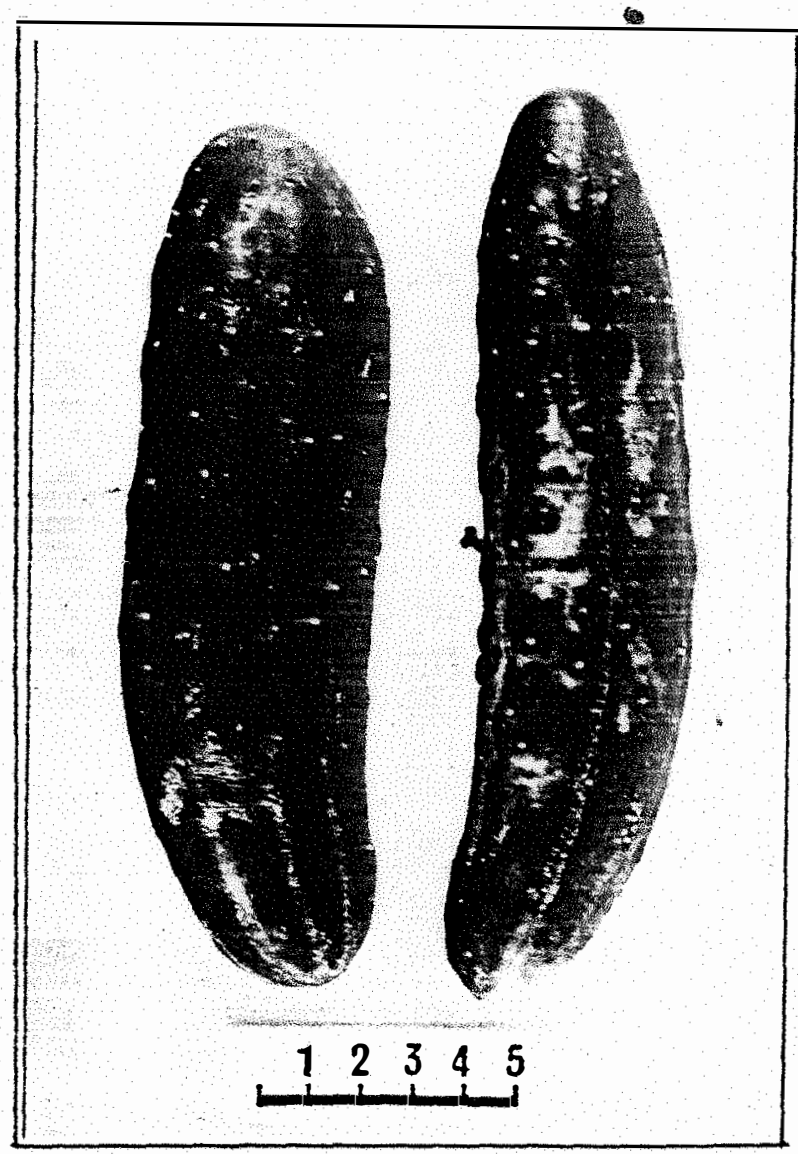

Fig. 1. Sintomas de ataque de virose em frutos de plantas de pepino CV. palomar IAC- 3050 obtidas por semeadura em 5 de maio de 1970 . (Esca la em cml. 


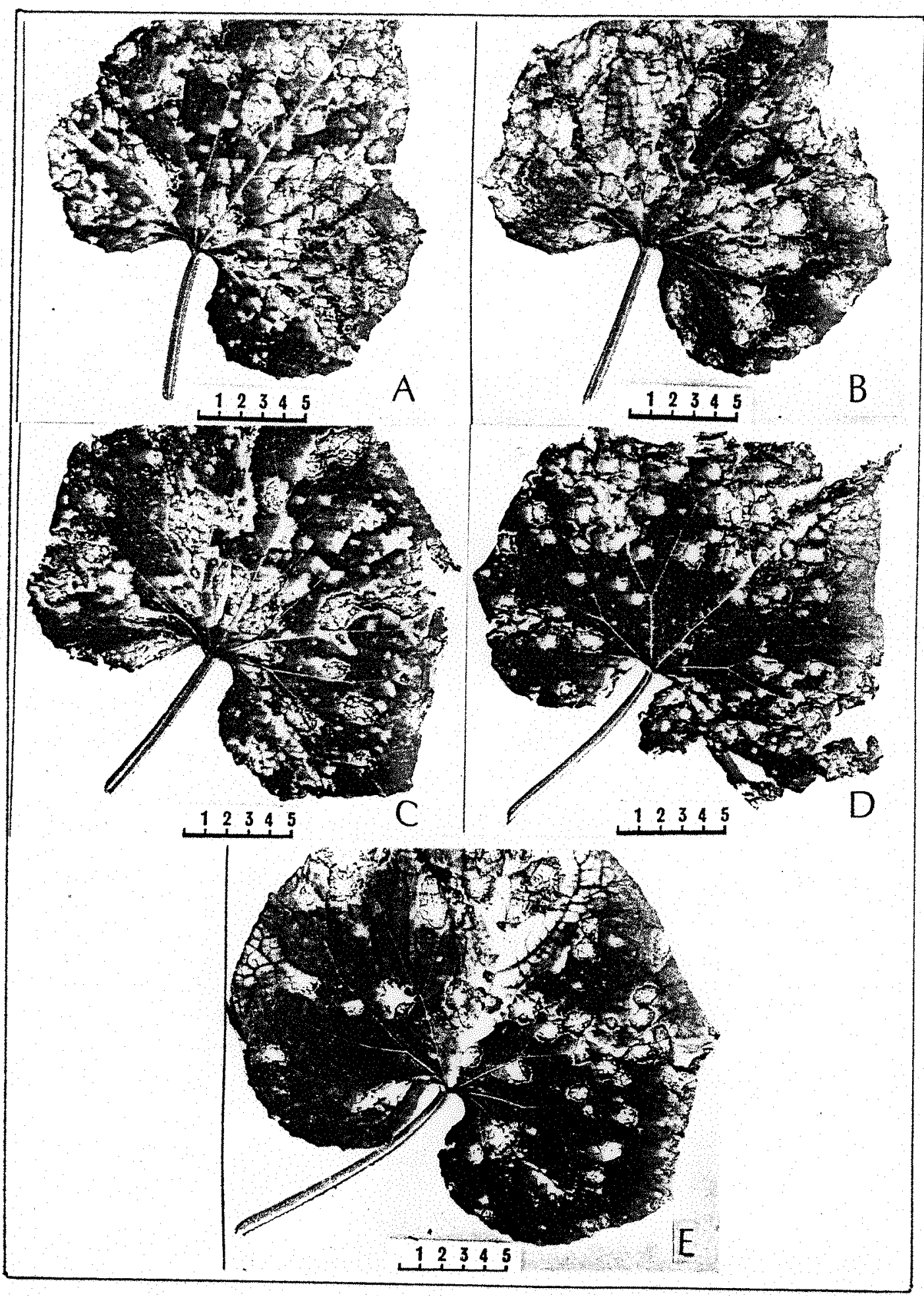

Fig. 2. Sintomas de ataque de Pseudoperonospora cubensis (Berk. e Curt.) Rostow. em folhas de plantas de diferentes cultivares de pepino obtidas por semeadu ra em 5 de dezembro de 1970 . ( $A=$ Marketer IAC $-2205 ; \mathrm{B}=$ Palomar IAC-3050; $\mathrm{C}=$ Santee I-2441; $\mathrm{D}=$ $=$ Verde Paulistano IAC-1386; $\mathrm{E}=$ Aodai I-4321). (ES 


$$
\text { e }
$$


57

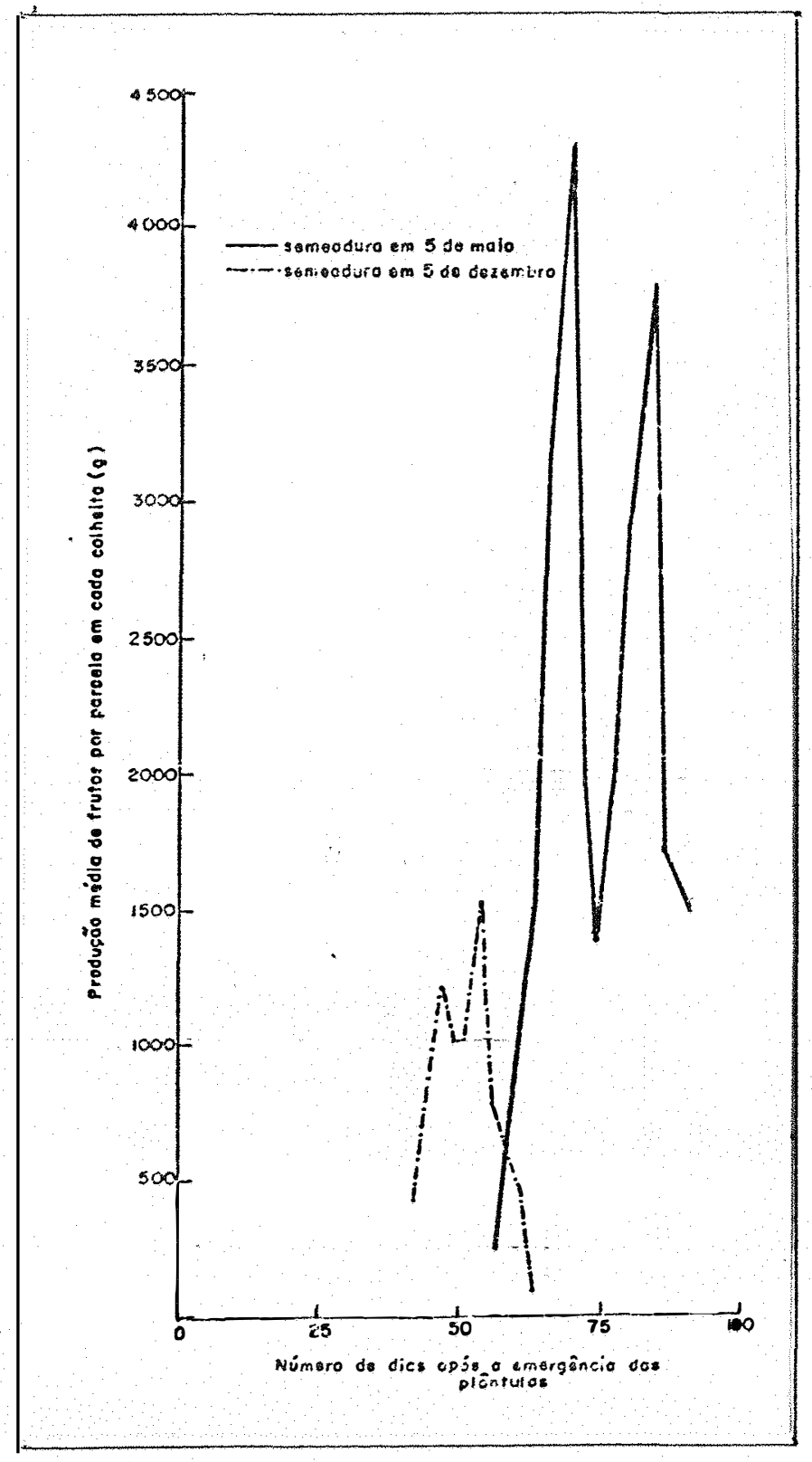

Fig. 4. Representação grâfica da produção em peso de frutos em relação à idade de plantas de diferentes cultivares de pepino obtidas por semeadura em 5 de maio e 5 de dezembro de 


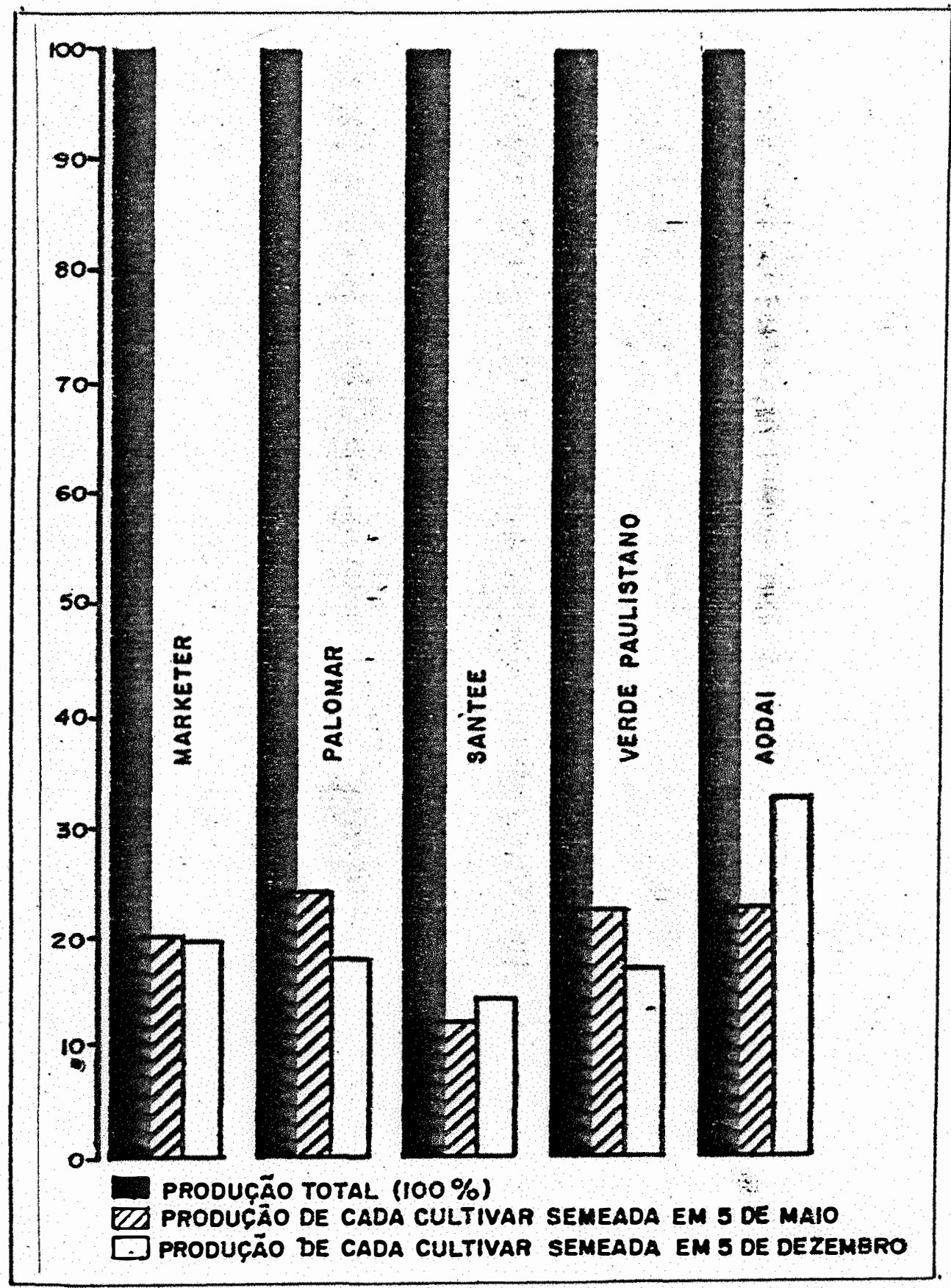

Fig. 5. Representação gráfica da porcentagem de produção de cada cultivar em relação à produção total de todas as cultivares de pepino em duas épocas de semeadura. 


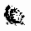

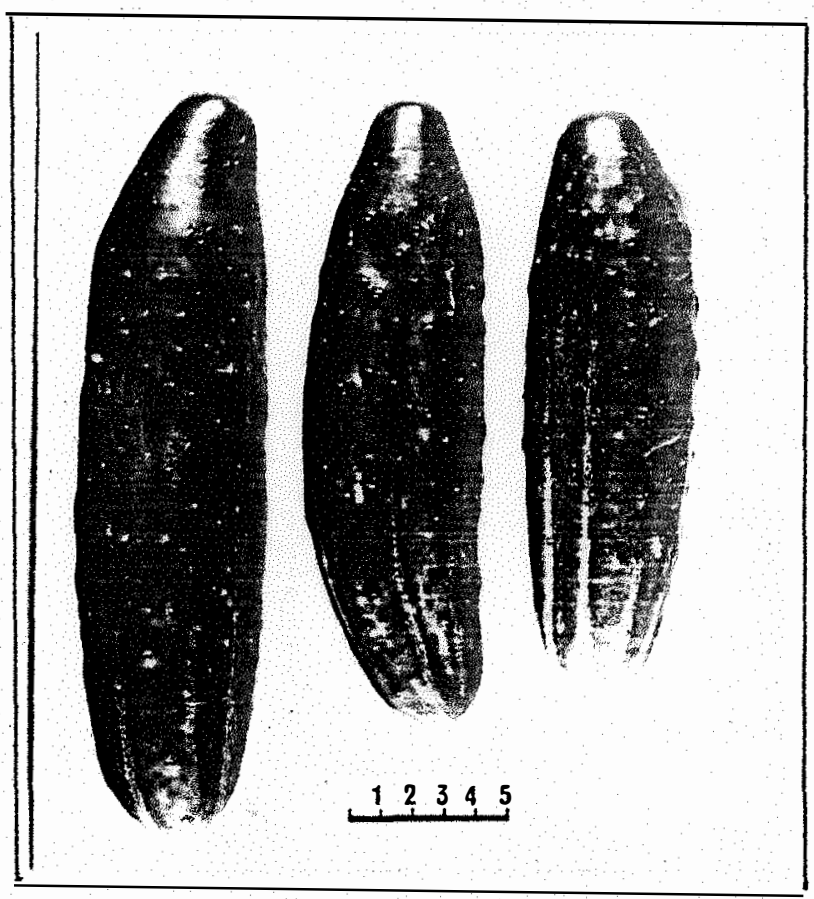

Fig. 6. Amostra de frutos da primeira colheita (7 de ju tho de 1970) de plantas -de pepino CV. Marketer IAC-2205 obtidas por semeadura em 5 de maio de 1970. (Escala em cm). 


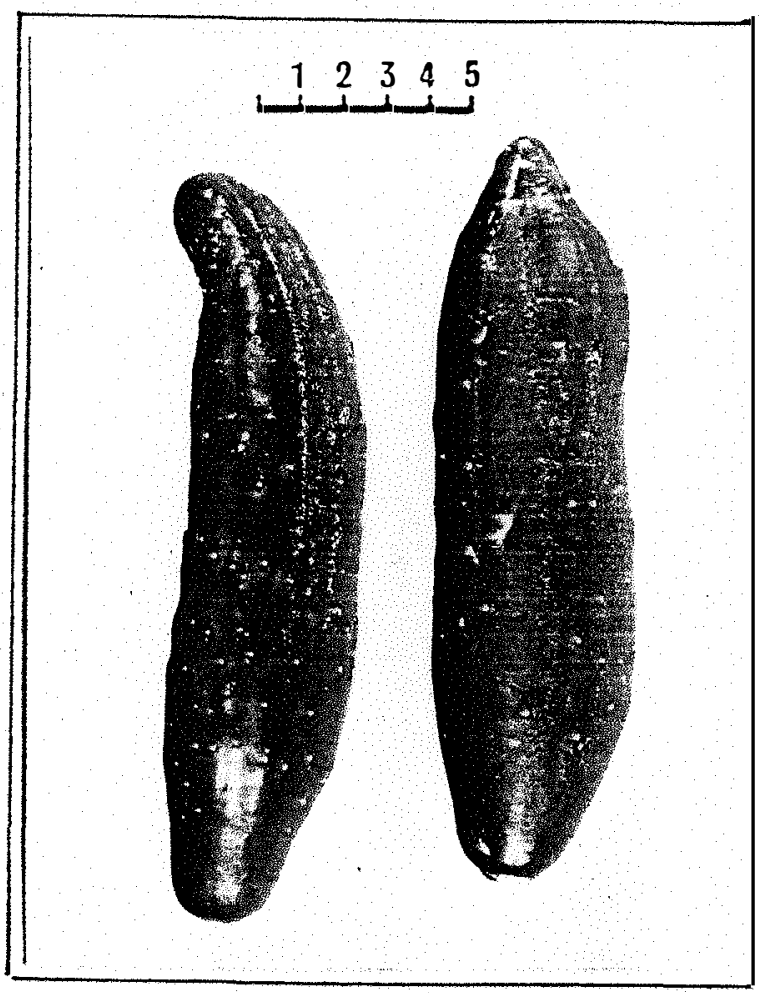

Fig. 7. Amostra de frutos da colheita de maior produção. ( 3 de agosto de 1970) de plantas de pepino cv. Marketer IAC-2205 obtidas por semeadura em 5 de maio de 1970. (Escala em cm). 
«

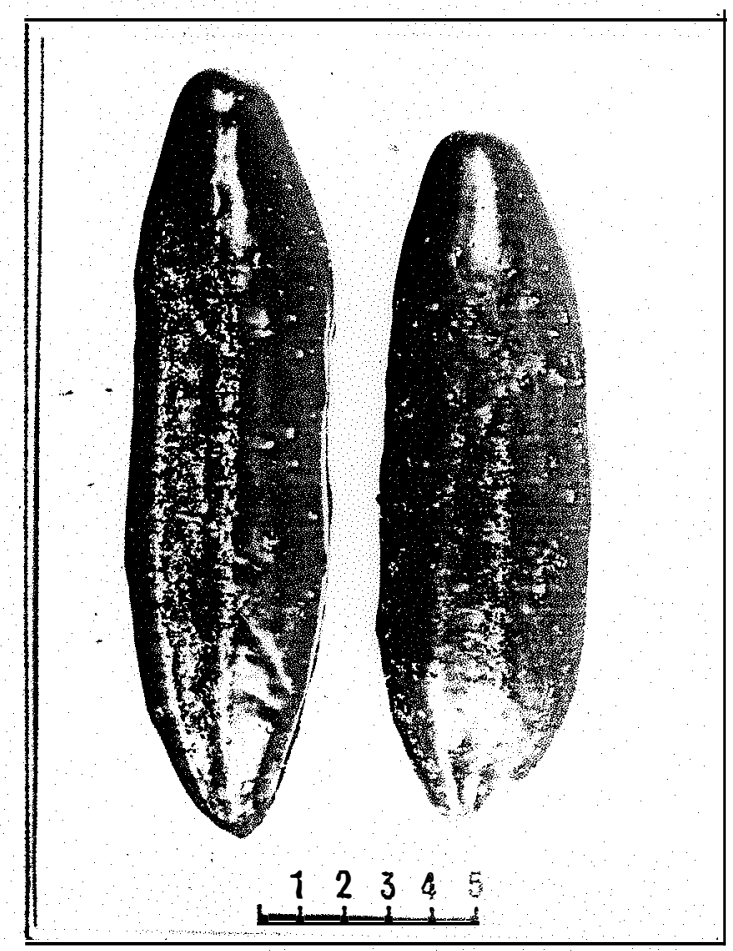

Fig. 8. Amostra de frutos da ūltima colheita $(11$ de agosto de 1970) - de plantas de pepino cv.Mar keter IAC-2205 obtidas por semeadura em 5 de maio de 1970. (Escala em $\mathrm{cm}$ ) . 


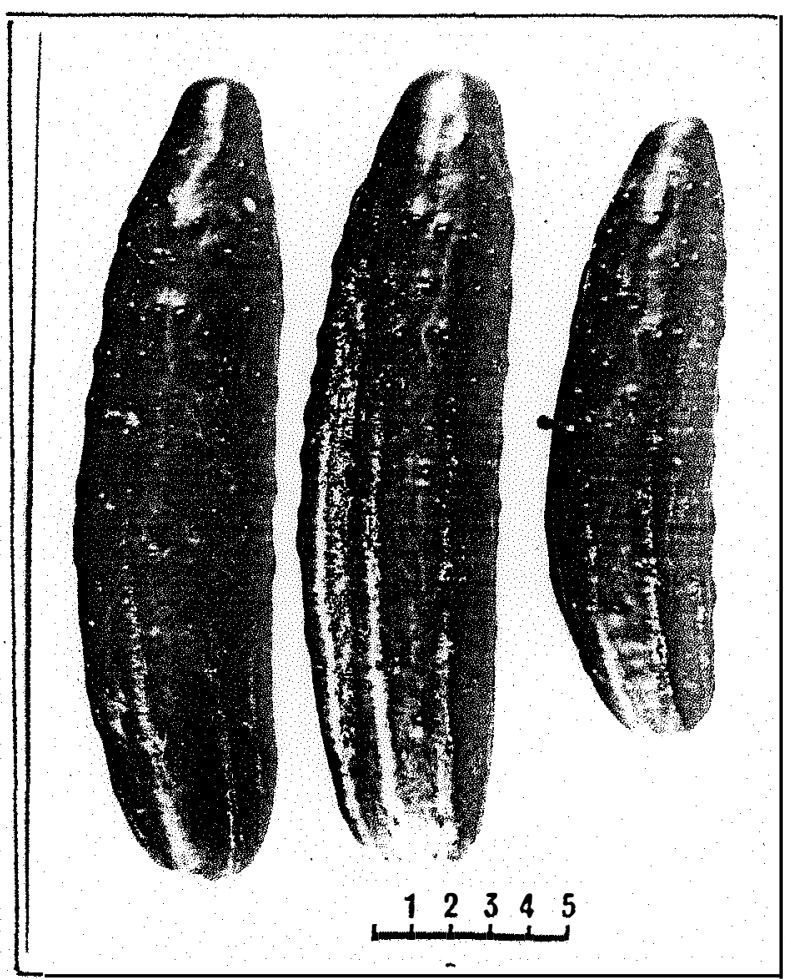

Fig. 9. Amostra de frutós da primeira colheita ( 7 de julho de 1970) de plantas de pepino cV. Palomar IAC-3050 obtidas por semeadura em 5 de maio de 1970. (Escala em cin). 


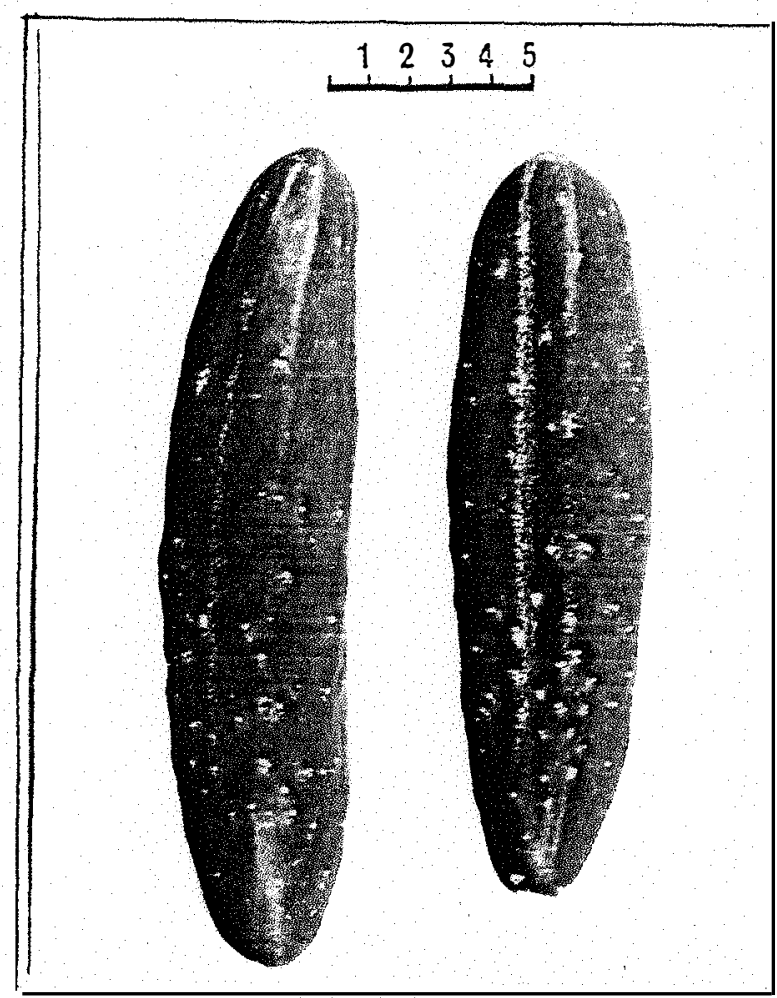

Fig. 10. Amostra de frutos da colheita de maior produção (20 de julho de 1970) de plantas de pepino cv. Palomar IAC-3050 obtidas por semeadura em 5 de maio de 1970. (Escala em cm). 


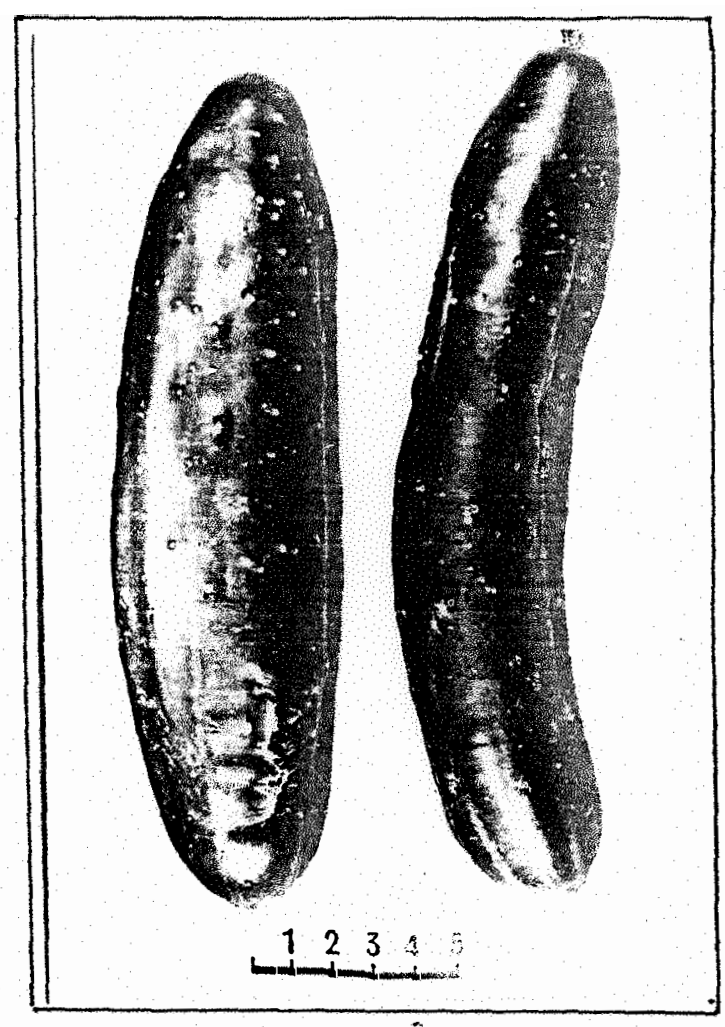

Fig. 11. Amostra de frutos da ültima colheita ( 11 de agosto de 1970) de plantas de pepino cv.Palomar IAC-3050 obtidas por semeadura em 5 de

- maio de 1970. (Escala em - cm). 


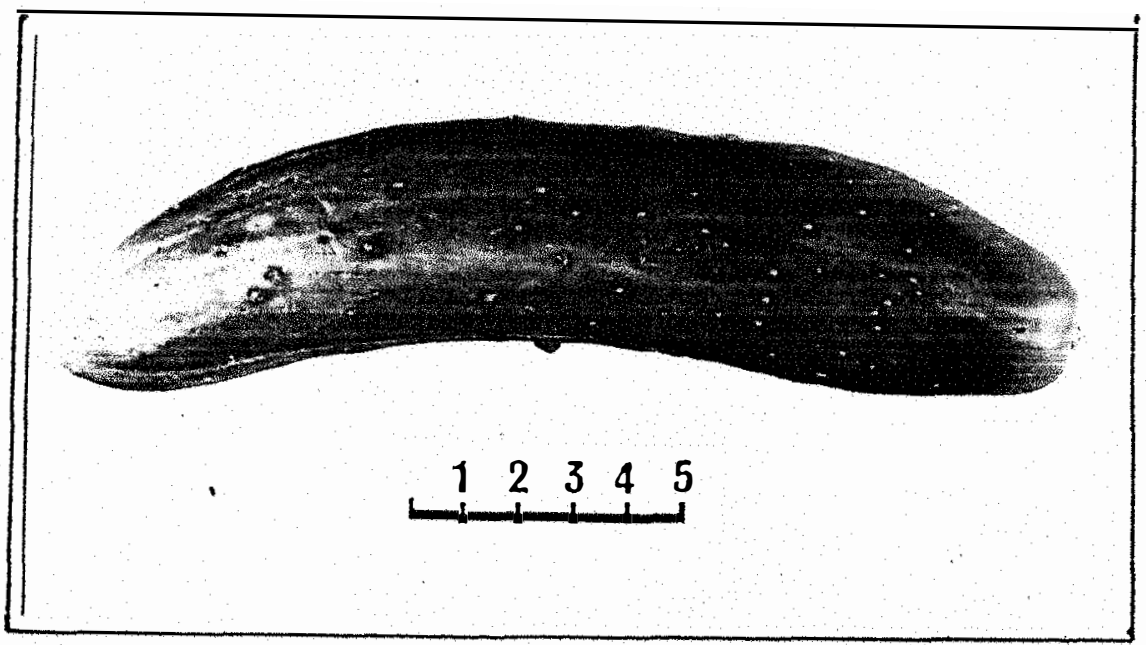

Fig. 12. Amostra de frutos da primeira co Iheita ( 7 de julho de 1970) de plantas de pepino cv. Santee I-2441 obtidas por se meadura em 5 de maio de 1970. (Escala em cm) . 


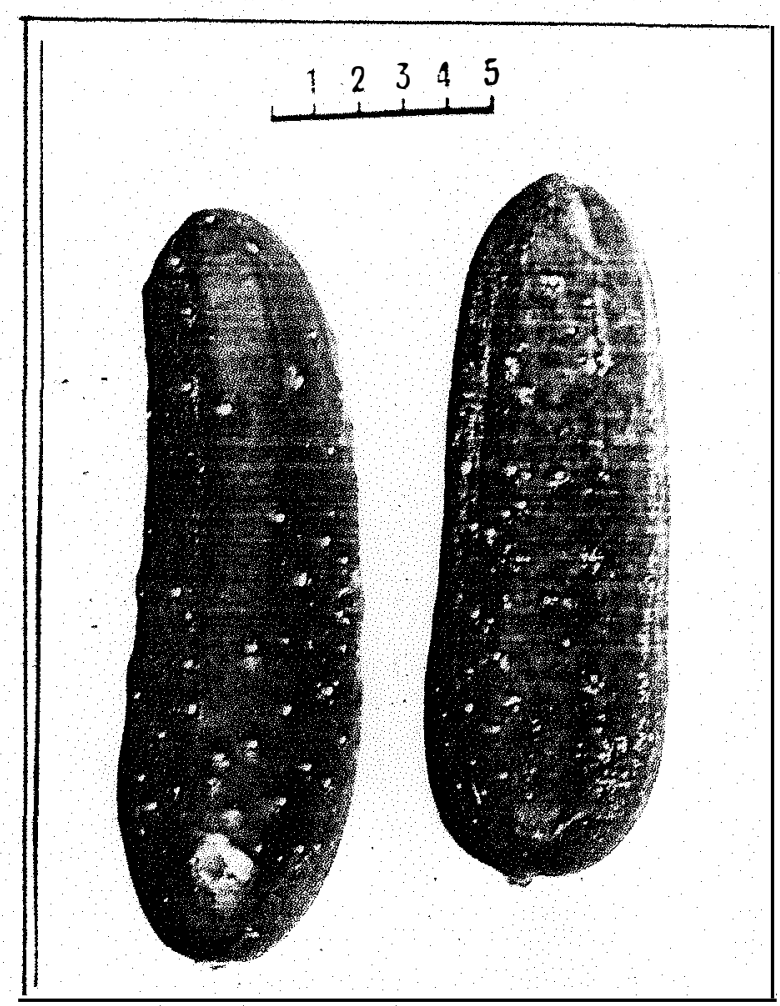

Fig. 13. Amostra de frutos da colheita de maior produção ( 3 de agosto de 1970) de plantas de pepino CV. San tee $I-2441$ obtidas por se meadura em 5 de maio de 1970. (Escala em cm). 


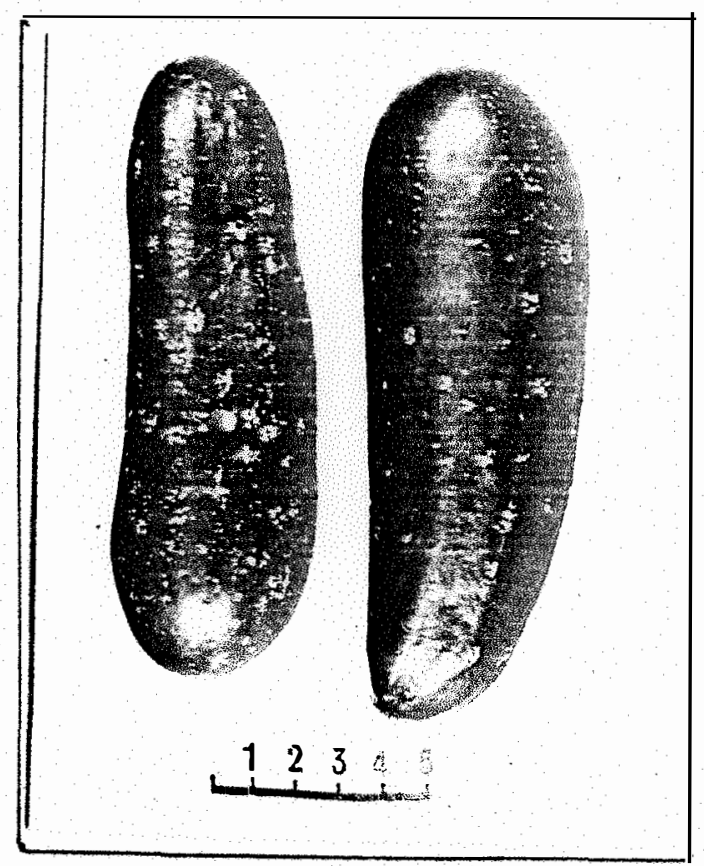

Fig. 14. Amostra de Erutos de ültima colheita ( 11 agosto de 1970) de plan tas de pepino cV. San - tee I-2441 obtidas por semeadura em 5 de maio de 1970. (Escala em cm). 


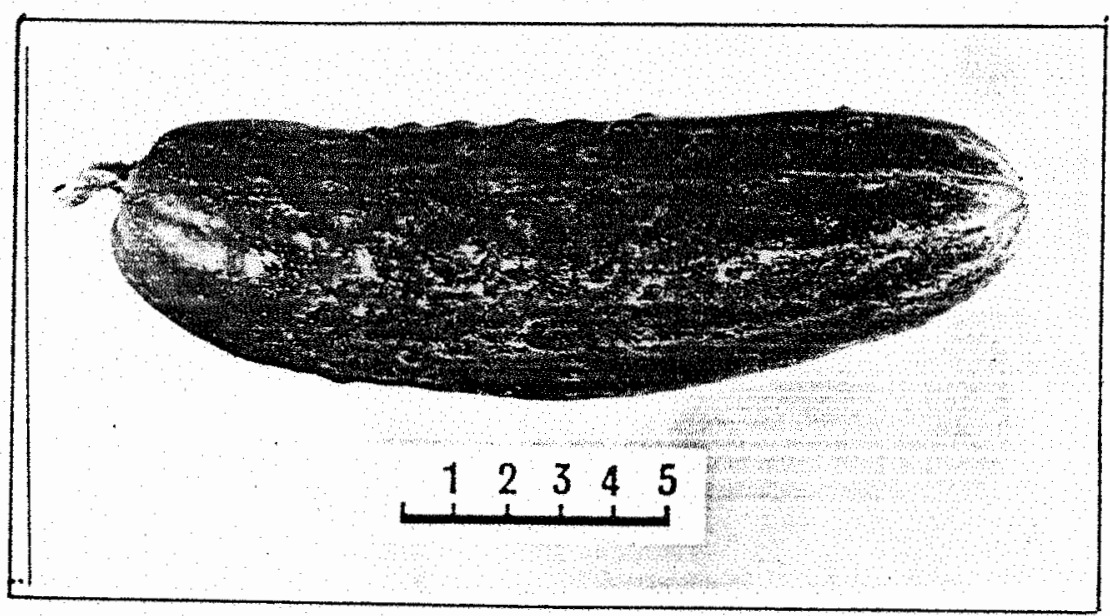

Fig. 15. Amostra de frutos da primeira co Iheita ( 7 de julho de 1970) de plantas de pepino cv. Verde Paulistano IAC- 1386 obtidas por semeadura em 5 de maio de 1970. (Escala em cm). 


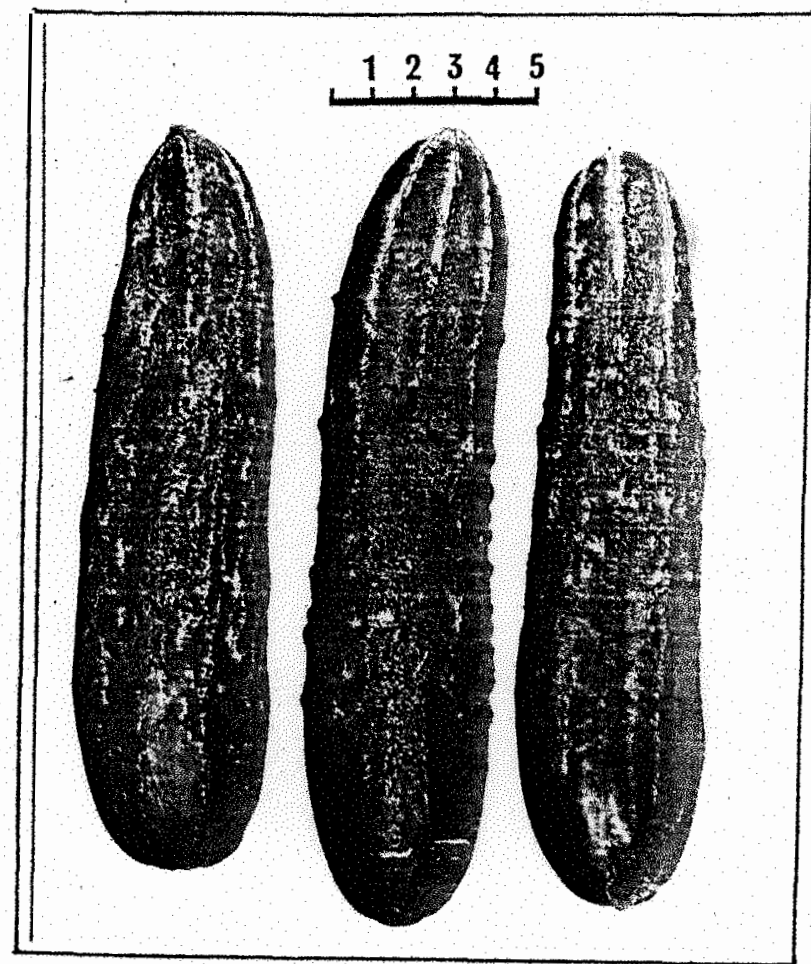

Fig. 16. Amostra de frutos da colheita de maior produção ( 16 de julho de 1970) de plantas de pepino cv. Verde - Paulistano IAC- 1386 obtidas por semeadura em 5 de maio de 1970. (Escala em cm). 


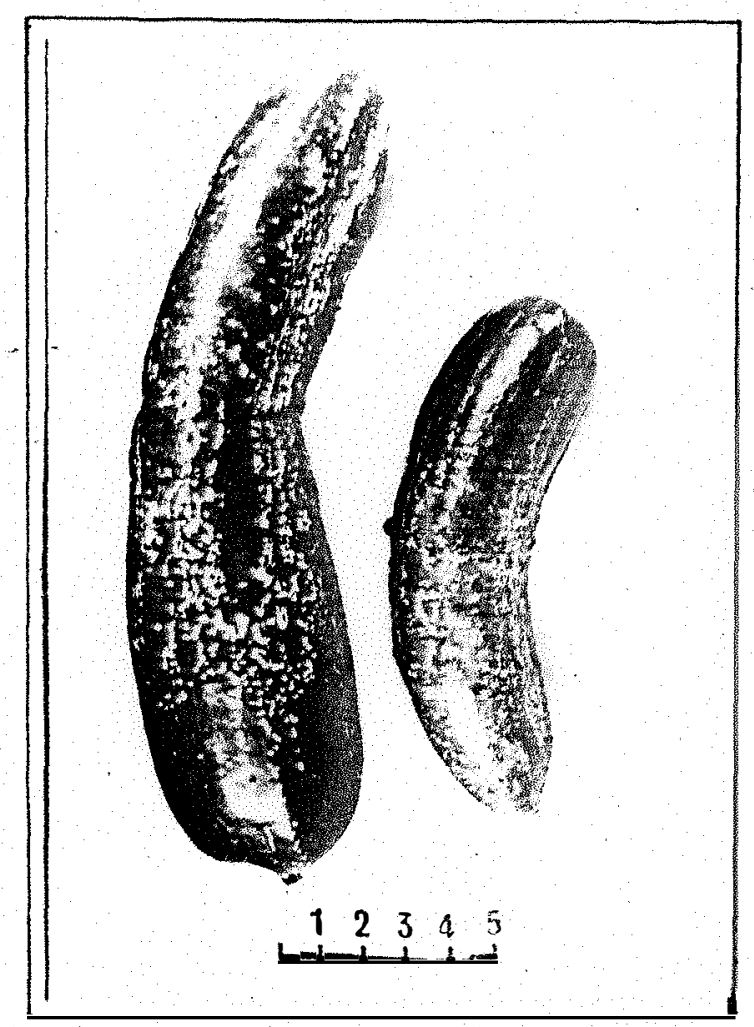

Fig. 17. Amostra de frutos da última colheita ( 11 de agosto de 1970) de plantas de pepino cv.Ver de Paulistano IAC- 1386 - obtidas por semeadura em - 5 de maio de 1970. (Esca la em cm). 


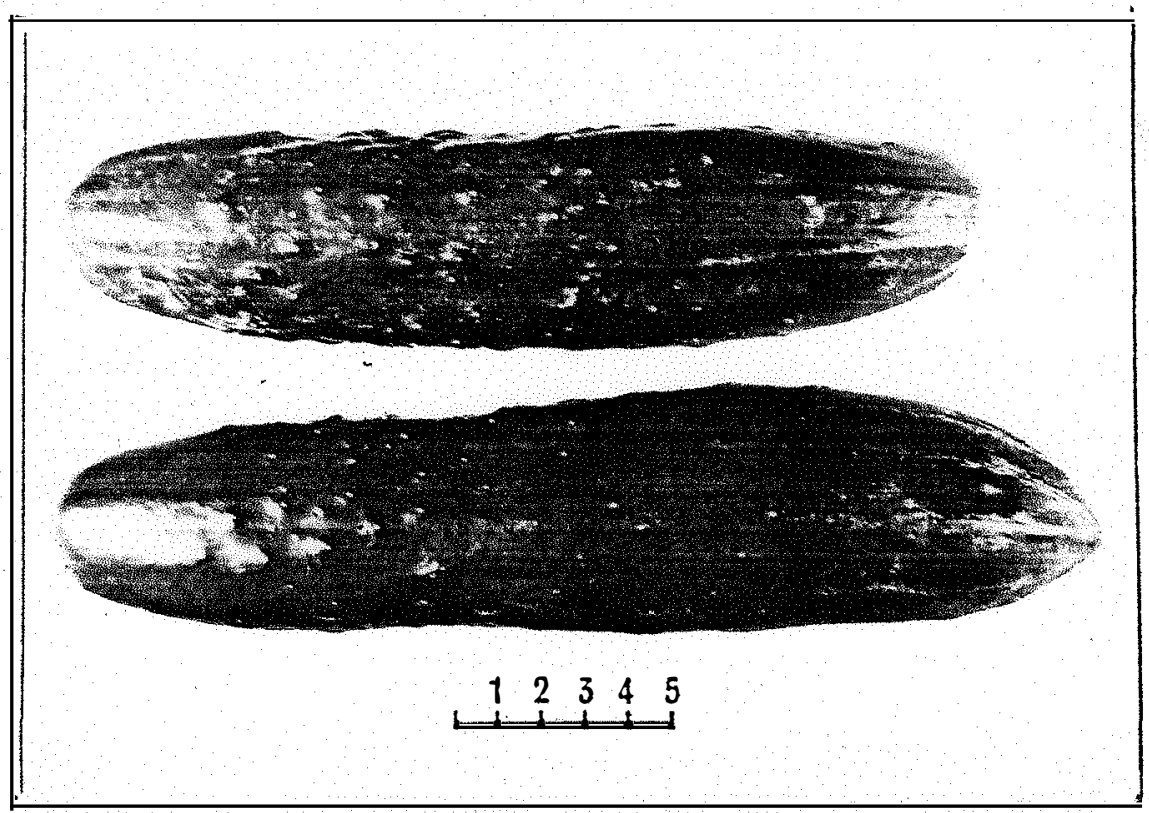

Fig. 18. Amostra de frutos da primeira colhei ta ( 7 de julho de 1970) de plantas de pepi no $\mathrm{CV}$. Aodai I-4321 obtidas por semeadura em 5 de maio de 1970. (Escala em cm). 


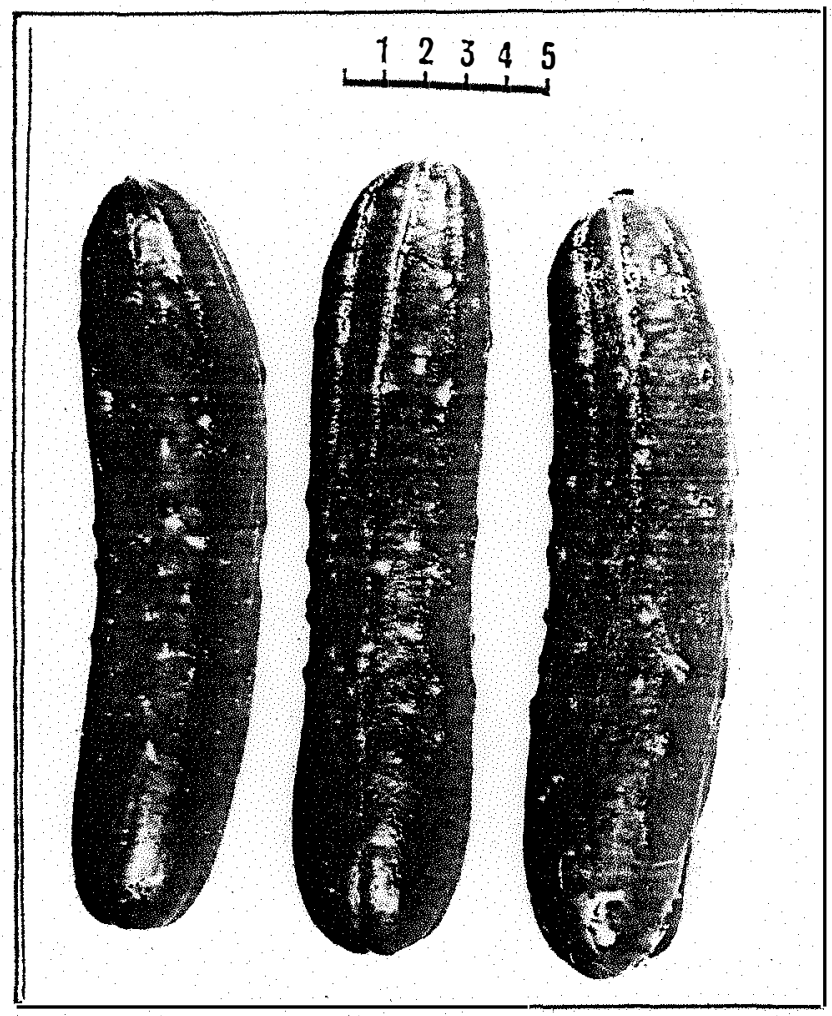

Eig. 19. Amostra de frutos da colheita de maior produção ( 3 de agosto de 1970) de plantas de pepino cv. Aodai I-4321 ob tidas por semeadura em 5 de maio de 1970. (Escala em cm). 


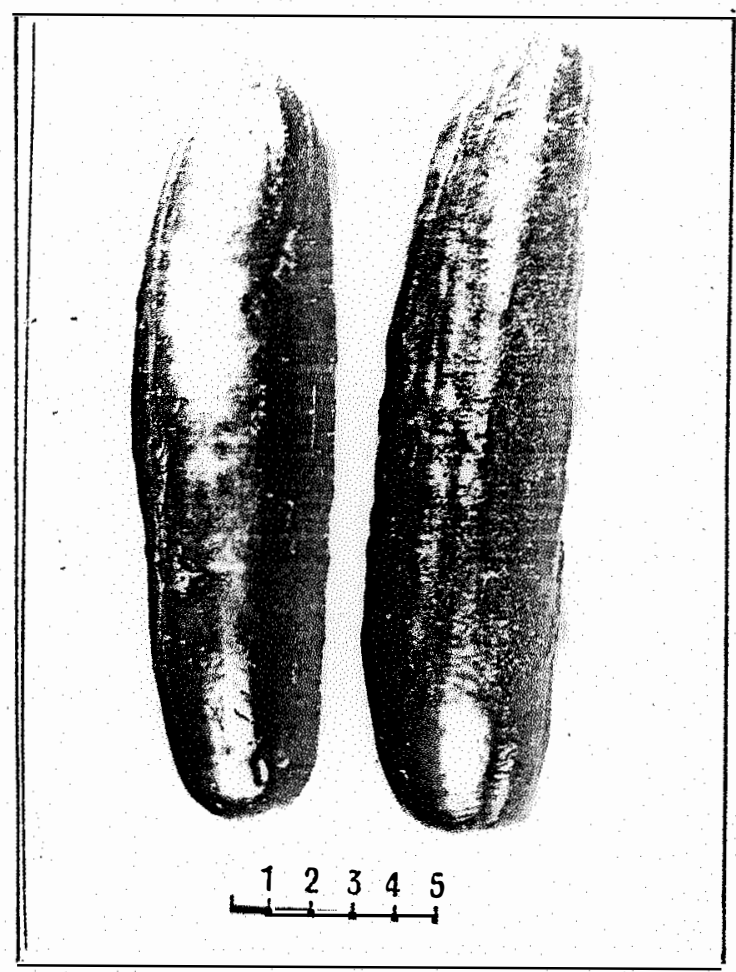

Fig. 20. Amostra de frutos da última colheita ( 11 de agosto de 1970) de plantas de pepino cv. Aodai I-4321 obtidas por - semeadura em 5 de maio de 1970. (Escala em cm). 


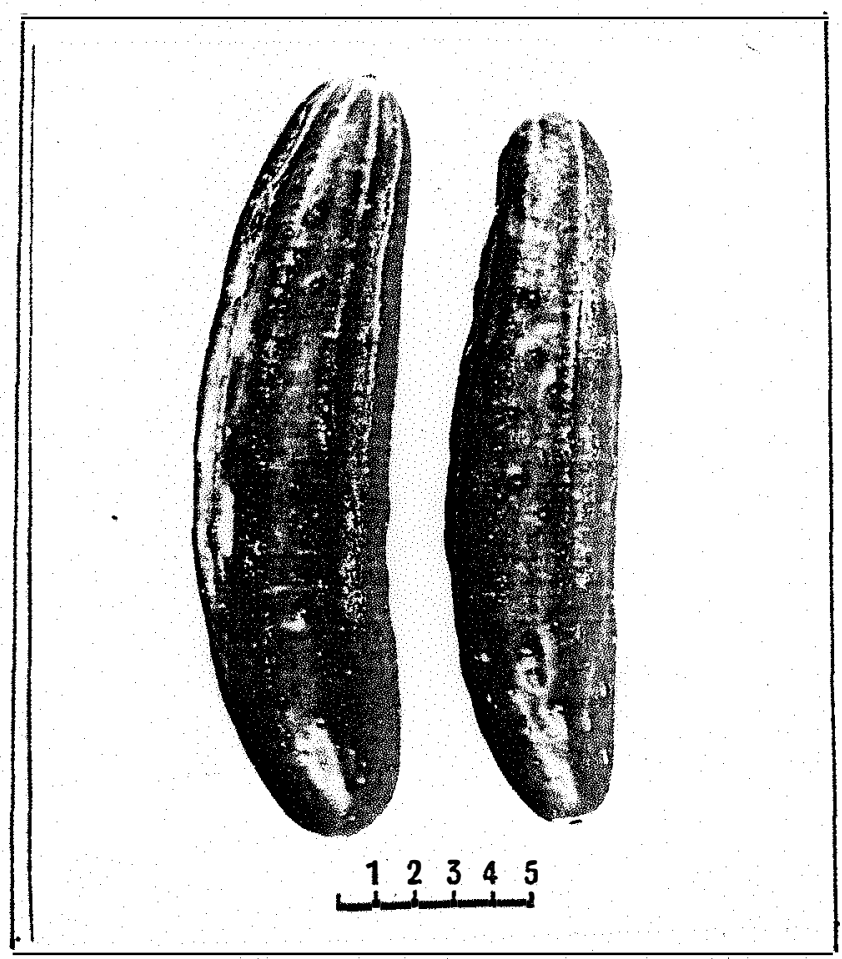

Fig. 21. Amostra de frutos da primeira colheita ( 20 de ja neiro de 1971) de plantas de pepino CV. Marketer IAC- 2205 obtidas por semeadura em 5 de dezembro de 1970. (Escala em cm). 


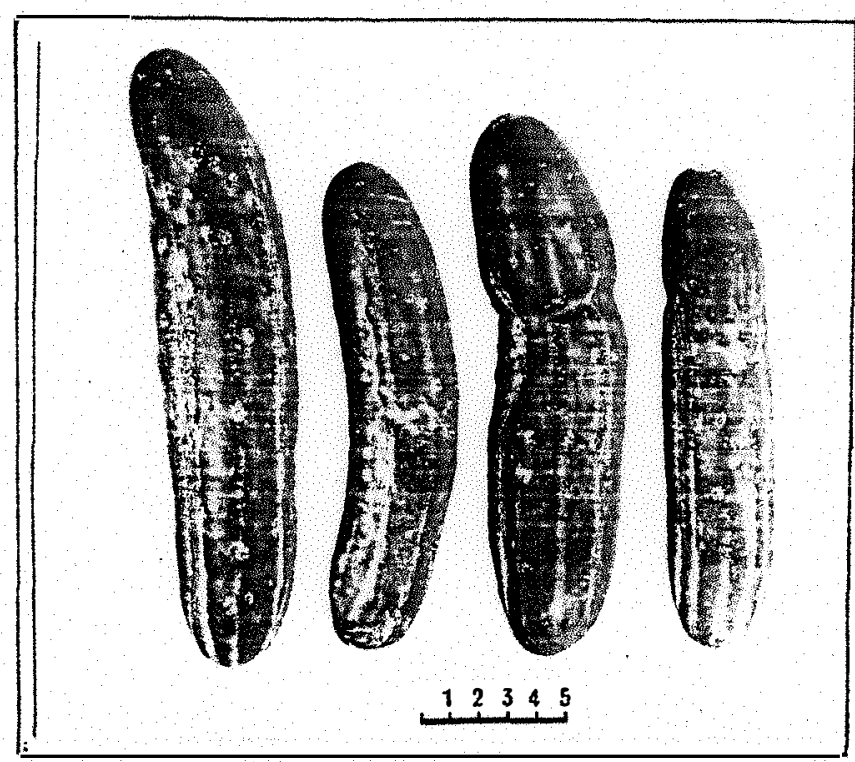

Fig. 22. Amostra de frutos da co theita de maior produção ( 25 de janeiro de 1971) de plantas de pepino cV. Marketer IAC -2205 obtidas por semeadura em 5 de dezembro de 1970. (Escala em cm). 
?

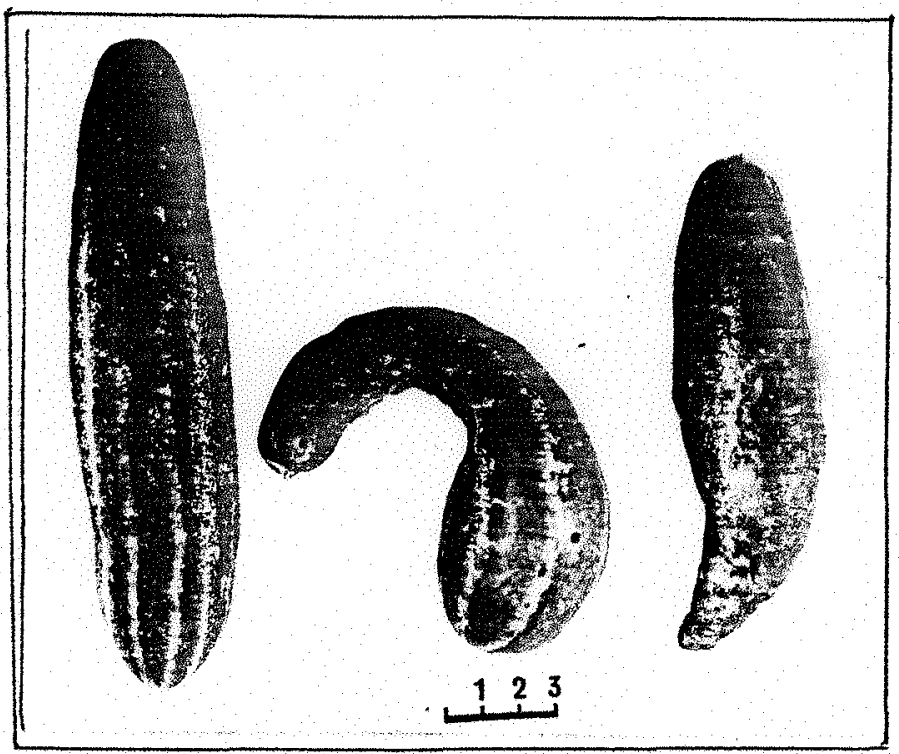

Fig. 23. Amostra de frutos da ūltima colheita (10 de fevereiro de 1971) de plantas de pepino cV. Marketer IAC-2205 obtidas por semeadura em 5 de dezembro de 1970. (Escala em cm). 
te

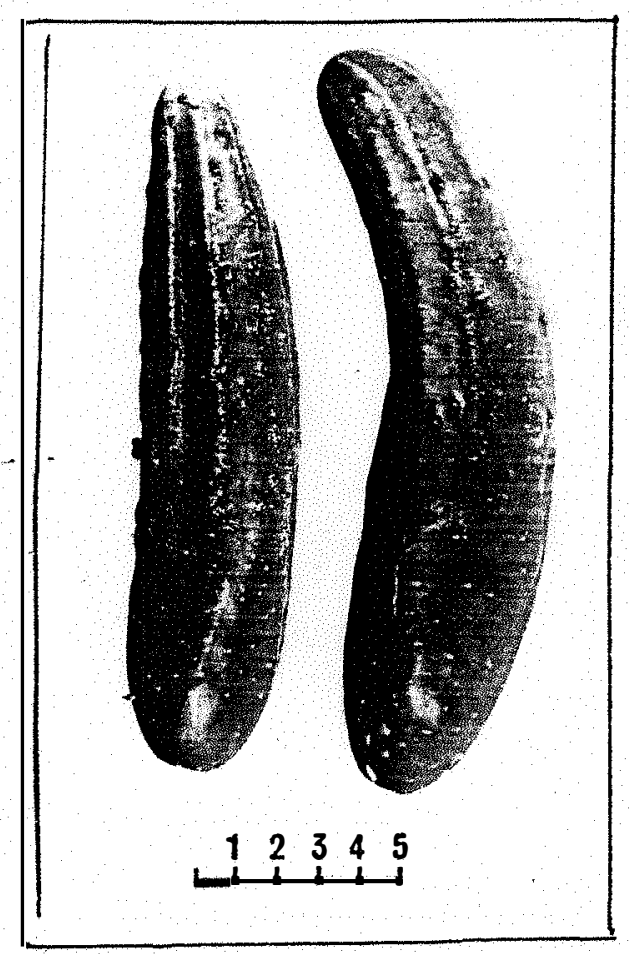

Fiq. 24. Amostra da pri meira colheita ( 20 de janeiro de 1971) de plantas de pepino cV.Palomar IAC- 3050 obtidas por semeadura em 5 de dezembro de 1970. (Escala em (cm) . 


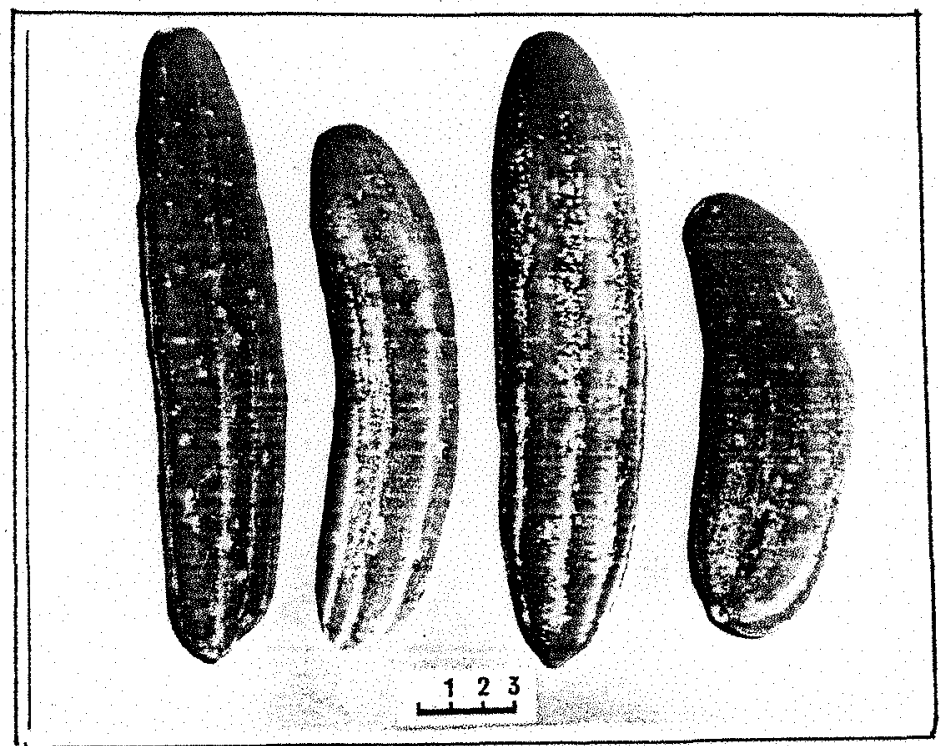

Fig. 25. Amostra de frutos da colhei ta de maior produção ( 3 de feve reiro de 1971) de plantas de pepi no cV. Palomar IAC-3050 obtidas por semeadura em 5 de dezembro de 1970. (Escala em cm). 


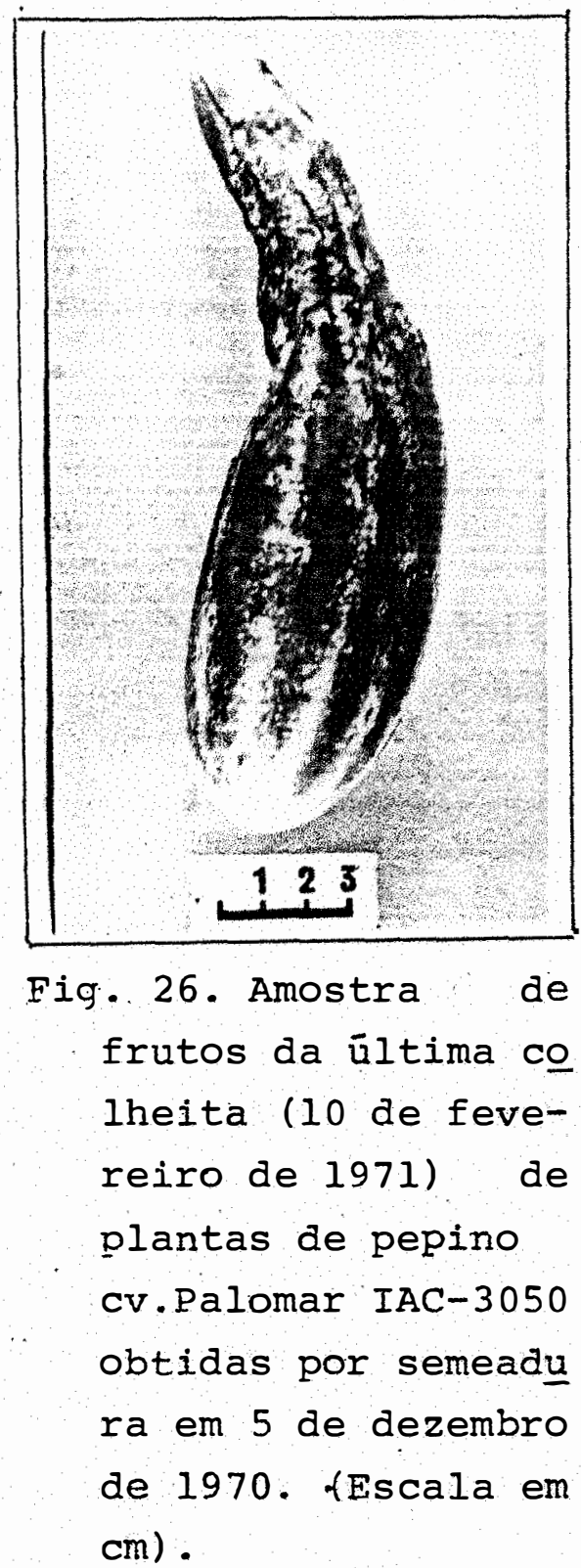




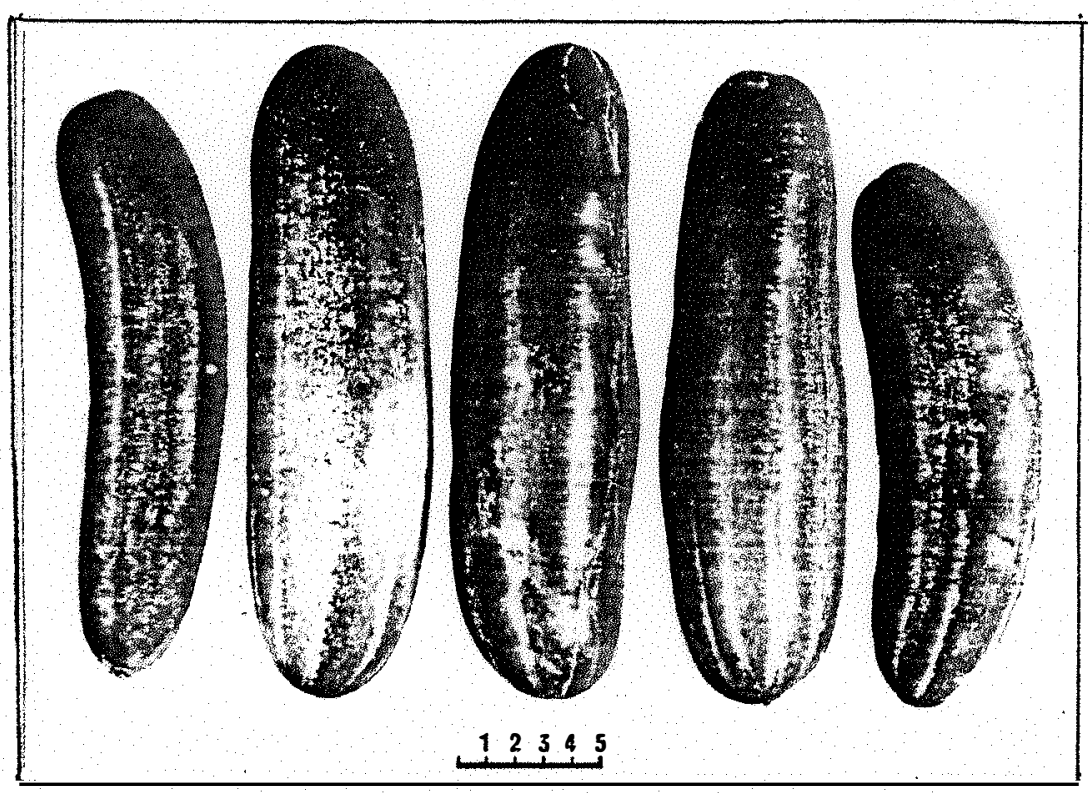

Fig. 27. Amostra de frutos da primeira coIheita (20 de janeiro de 1971) de plantas de pepino CV. Santee I-2441 obtidas por semeadura em 5 de dezembro de 1970 . (Escala em cm). 


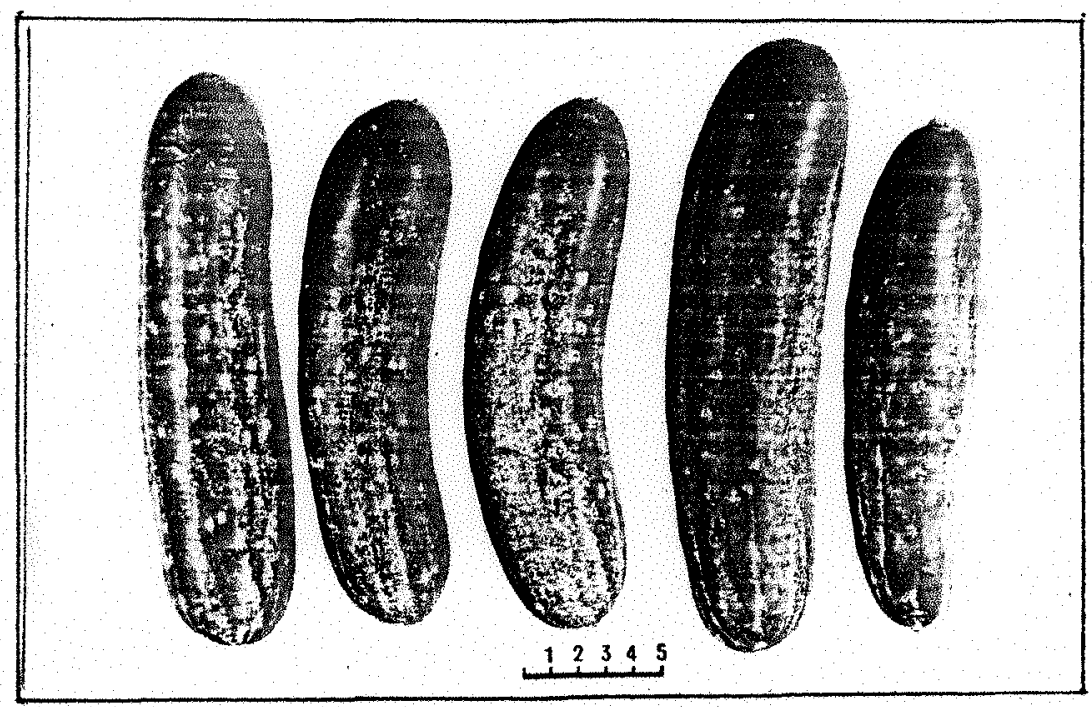

Fig. 28. Amostra de frutos da colheita de maior produção (25 de janeiro de 1971 ) de plantas de pepino cv. Santee I-244I obtidas por semeadura em 5 de dezembro de 1970. (Escala em cm). 


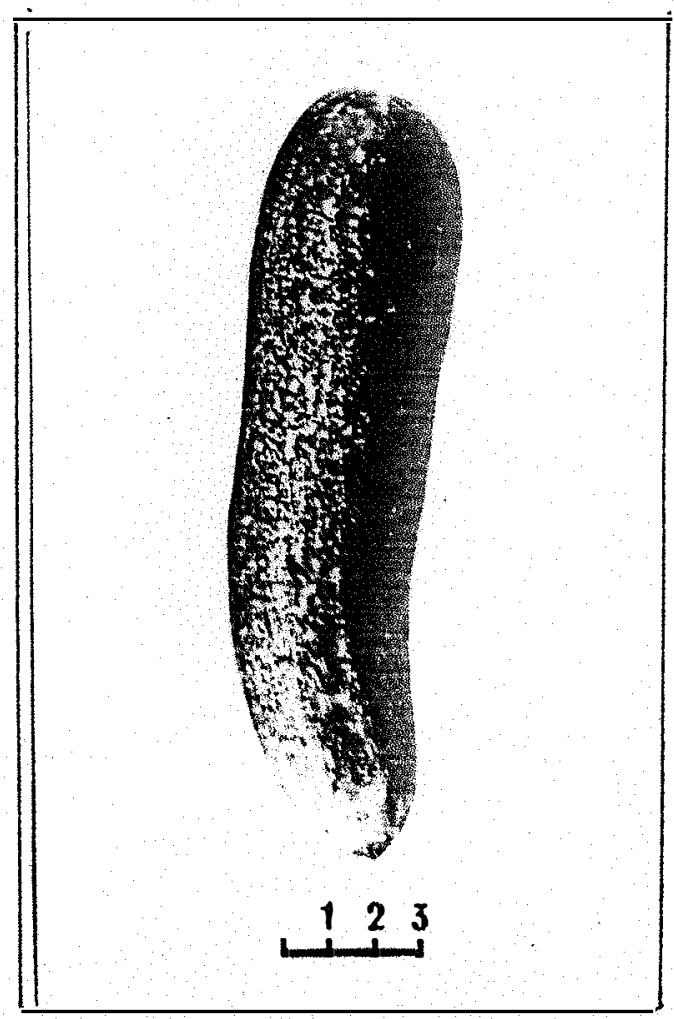

Fig. 29. Amostra de frutos da ulltima colheita ( 10 de fevereiro de 1971) de plantas de pepino cv. Santee I-2441 obtidas por semeadura em 5 de dezembro de 1970 . (Escą - la em cm). 


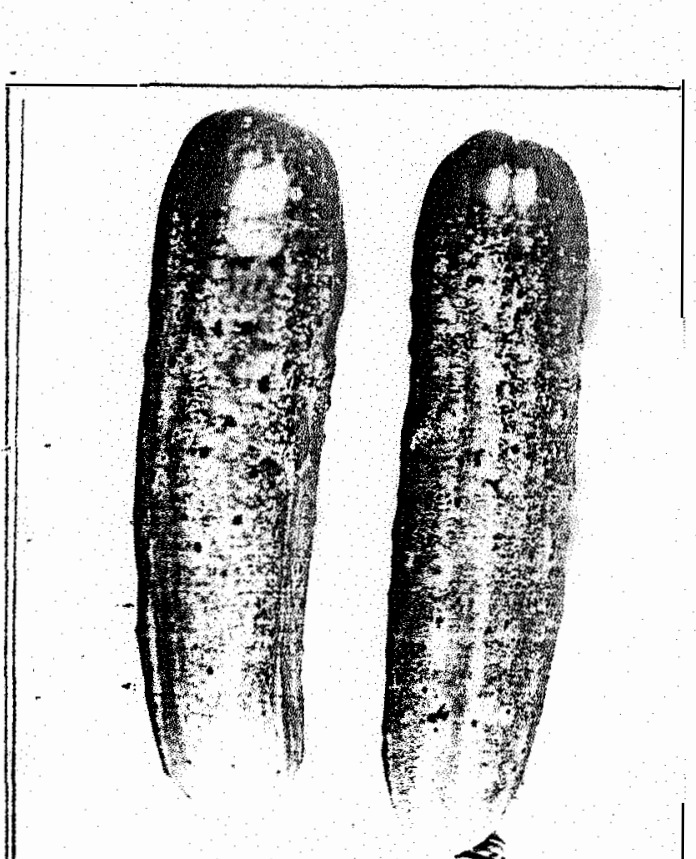




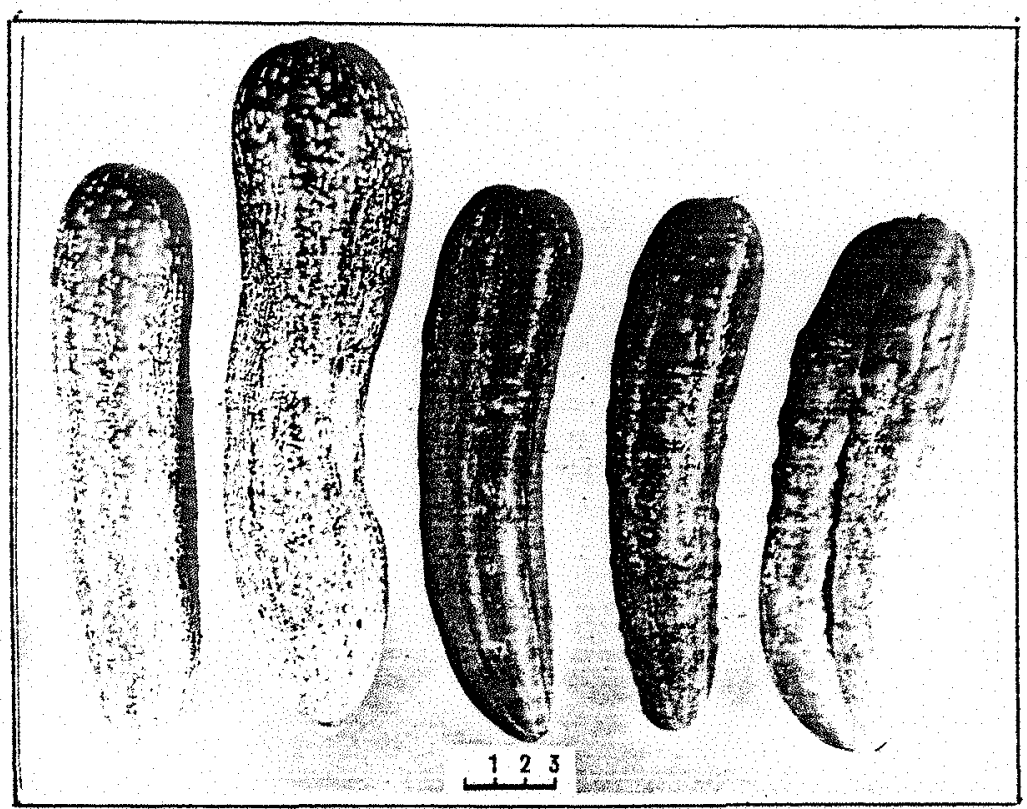

Fig. 31. Amostra de frutos da colheita de maior produção ( 1 de fevereiro de 1971) de plantas de pepino cV. Verde Paulistano IAC-1386 obtidas por semeadura em 5 de dezembro de 1970. (Escala em cm). 


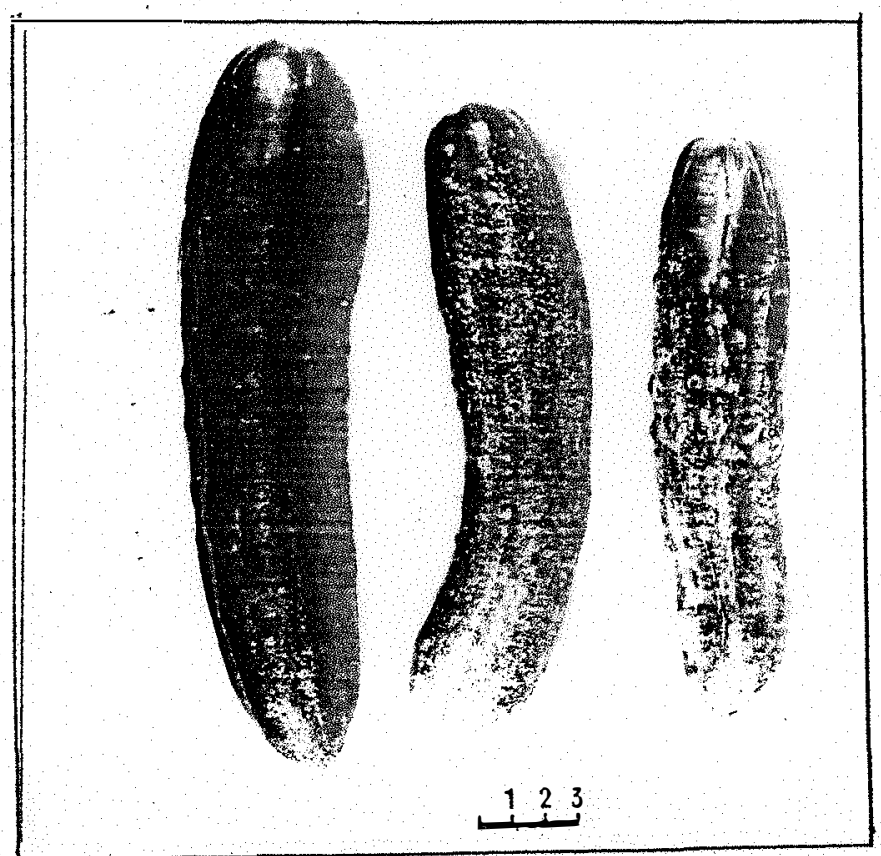

Fig. 32. Amostra de frutos da ūlti ma colheita (10 de fevereiro de 1971) de plantas de pepino cv. Verde Paulistano IAC- 1386 obtidas por semeadura em 5 de dezem bro de 1970. (Escala em cm). 


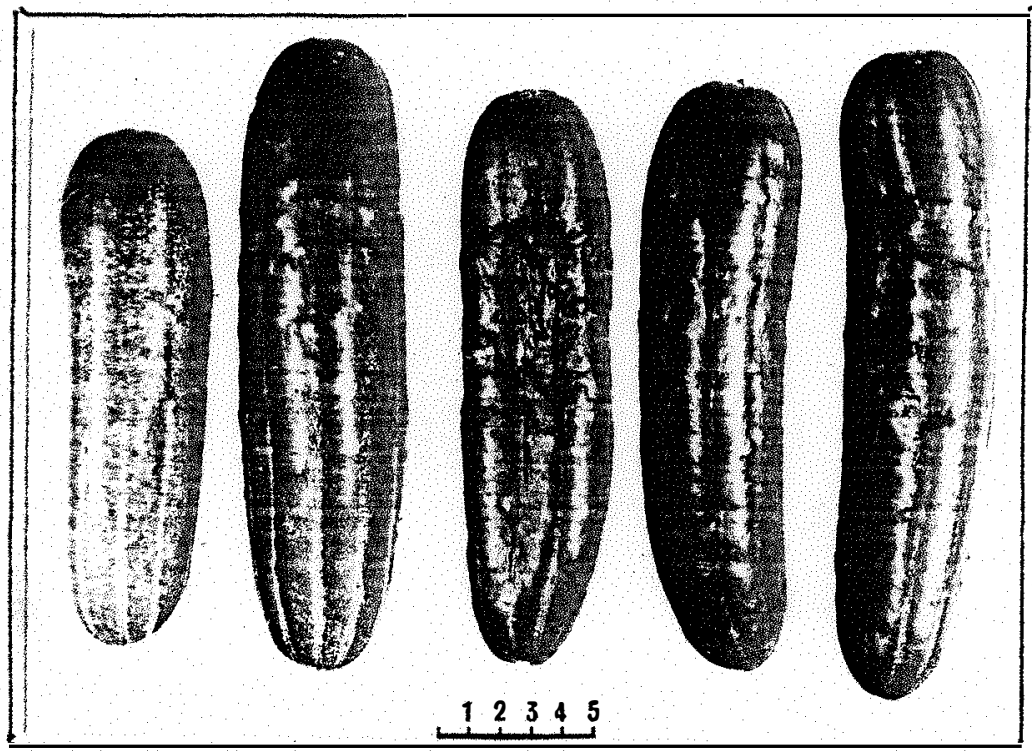

Fig. 33. Amostra de frutos da primeira colheita (20 de janeiro de 1971) de plantas de pepino cv. Aodai I- 4321 obtidas por semeadura em 5 de dezem bro de 1970. (Escala em cm). 
(x)

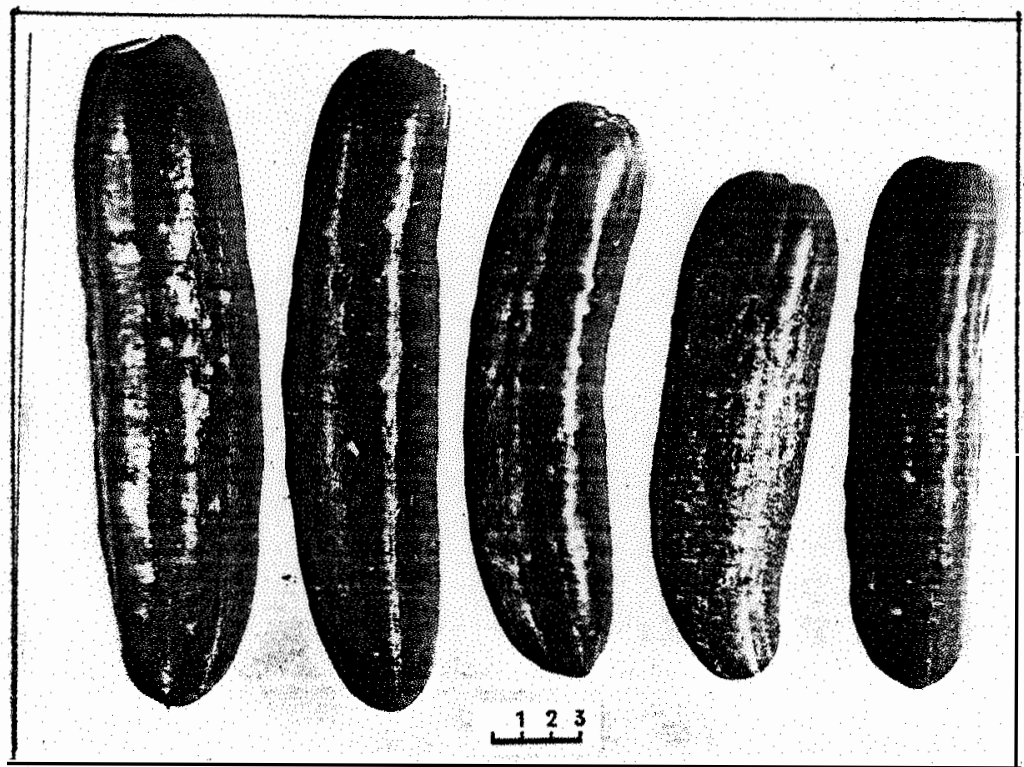

Fig. 34. Amostra de frutos da colheita de maior produção ( 1 de fevereiro de 1971) de plantas de pepino cv. Aodai I-4321 obtidas por semeadura em 5 de dezembro de 1970. (Escala em cm). 
d 


\section{DISCUSSÃO}

A temperatura mínima de $15,2^{\circ} \mathrm{C}$, registrada em maio de 1970 (Tabela 2), não prejudicou a germinação das semen tes, conforme se poderia esperar com base em informações de KNOTT (1966) e SEGET'A (1966).

Embora a temperatura média mensal de maio de 1970 estivesse compreendida entre $12,0{ }^{\circ}$ e 23,0 ${ }^{\circ} \mathrm{C}$ (Tabela 2) , não se observaram diferenças na porcentagem de germinação entre as sementes das diferentes cultivares, diferenças essas que, segundo NILSSON (1968) e SCHULTE e GROTE (1974), poderiam ocor rer nessas condições.

Os dados das Tabelas 3 e 5 indicam que, na pri meira êpoca de semeadura, as flores masculinas se formaram apōs um menor nủmero de nôs nos ramos das plantas, em compara ção com a segunda época. Entretanto, esperava-se que isso ocorresse com as flores femininas, devido às temperaturas mais baixas e aos fotoperíodos mais curtos ocorridos na primeira êpoca, que, como informaram NITSCH et a $i i$ (1952), favoreceriam o aparecimento de flores femininas: tal fato não foi obse $\underline{r}$ vado. 
Os dados das Tabelas $4,6,7311$ seguem a tendên cía descrita por MILLER e QUISENBERRY (1976); a cultivar Verde Paulistano, cuja produçẫo mostrou-se mais tardia, apresentou tambển floraçẫo mais tardìa.

Apesar de não ter sido possîvel comparar o nüme ro de dias decorridos desde a emergência das plântulas até a primeira colheita, o comprimento mêdio do ramo principal e a mêdia do nûmero de ramificações laterais das plantas da primei ra êpoca de semeadura com as da segunda época (Tabelas 7 e 11), as mẻdias parecem mostrar que as plantas se desenvolveram mais e com maior rapidez na segunda êpoca de semeadura, o que pode ria ser explicado pelas temperaturas e fotoperíodos mais favo râveis dessa êpoca (Tabela 2), conforme diversos autores cita dos na revisão da literatura.

Quanto à produção de frutos, os melhores resul tados obtidos na primeira época de semeadura (Tabelas 9,14 e 16) podem ser explicados de diversos modos. A precipittação pluvial foi menor e a insolaça total foi maior nesse pe rî́odo, em comparação com a segunda época (Tabela 2); isso, de acordo com a literatura revista, favoreceria o desenvolvimento e a produção das plantas semeadas na primeira época. Póde ter sido prejudicial às plantas do segundo campo o fato de terem sido cultivadas no mesmo local do primeiro campo; houve, por exemplo, maior incidência de míldio, que jả ocorrera em peque na intensidade na primeira época. Além disso, as temperaturas mais elevadas, ocorridas na segunda época, são, como informam WHITAKER e DAVIS (1962), favorâveis à infestação da maioria das doenças e pragas que atacam o pepino.

As temperaturas registradas na primeira época, entretanto, foram menos vantajosas para o desenvolvimento das plantas do que as registradas na segunda época, como se pode concluir pela comparação dos dados da Tabela 2 com a revisão de literatura. A temperatura mínima registrada na êpoca do início da cultura foi inferior a $16,0^{\circ} \mathrm{C}$ e isso, segundo föLS TER (1974 a), poderia ter afetado por algum tempo o crescimento das plântulas. 
A ìncidência de virose na prìmeira época de semea dura pode ter sido causada pelas temperaturas mais baixas regis tradas nessa época, mais favorâveis, de acordo com DORSET (1975), à manifestaçẫo do CMV .

A preferência de Margaronia sp. pelos frutos da cultivar Verde Paulistano, relatada por CASTRO et alii (1976), foi observada neste estudo e, provavelmente, causou a queda de produção dessa cultivar em relação às demais, verificada na se gunda êpoca de semeadura (Tabela 14).

Quanto ao ataque de mîldio, entretanto, Palomar e Santee, consideradas resistentes por WHITAKER e DAVIS (1962) e MURILLO et alii (1963), apresentaram infestações equivalentes às das demais cultivares.

o fungicida Benlate, utilizado neste estudo, em pulverizações preventivas contra oídio, está, atualmente, sob suspeita de ser altamente nocivo à saúde humana e, portanto, seu uso não ê recomendável.

A correlação postivá encontrada entre produção e média do nümero de ramificações laterais das plantas da pri meira ëpoca de semeadura (Tabela 10), também verificada para outras espécies por autores citados na revisão de literatura, era esperada, porque os ramos laterais apresentam, geralmente, maior proporção de flores femininas, que dão origem aos frutos; alëm disso, as flores femininas do ramo principal não têm alta porcentagem de pegamento, como demonstrou RAMALHO (1973) para a cultivar Aodai. Provavelmente, a correlação não foi significativa na segunda êpoca por ter havido maior variação no comporta mento das plantas, como se verifica pela comparação das Tabelas 7,8 e 9 como as Tabelas 11,12 e 14 , respectivamente.

A cultivar Santee não apresentou flores femininas no ramo principal, o que, de acordo com TrEDJENS (1928 a), favo receria a produção de maior porcentagem de frutos bem formados. No entanto, evidenciou-se a inferioridade da produção de Santee em relação às demais cultivares, tanto em produção total como em produçẫo comerciâvel. 
Do mesmo modo que em outras plantas estudadas em trabalhos citados na revisão de literatura, a produçẫo em peso de pepino, no presente experimento; apresentou correlação posi tiva com o nümero de frutos produzidos (Tabelas 10 e 15).

A tendência da produção a correlacionar-se posití vamente com o comprimento do ramo principal, observada neste es tudo (Tabelas 10 e 15), parece ser verdadeira, porque coincide com os resultados obtidos por NIGMANOVA (1963), SACHAN e TIKKA (1971) e ABDEL-AL et alii (1973), para plantas da mesma família do pepino.

Dentro de uma mesma êpoca, o peso médio dos fru tos foi pouco afetado pelo ambiente, como indicam os coeficien tes de variação calculados (Tabelas 9 e 14), o que estâ de acor do com os resultados relatados por GREBENS̆C̆́IKOV (1963 e 1967) para Cucurbita spp.; entretanto, no presente estudo, o peso mé dio dos frutos pareceu ser maior na segunda época de semeadura.

Embora não se tenha medido o comprimento de todos os frutos colhidos, observações esparsas comprovaram a correla ção encontrada por CARLSSON (1962): os frutos de Verde Paulista no e Aodai, que apresentaram maior peso médio, foram os mais compridos.

A tendência de diminuir a relação entre produção comerciâvel e produção total à medida que a idade da planta au mentou (Tabelas 10 e 15) não estâ de acordo com a afirmação de STENE (1964) de que os frutos produzidos nos primeiros nós do caule, isto $\ddot{e}$, aqueles obtidos nas primeiras colheitas, são fre quentemente de qualidade inferior aos demais. Por outro lado, os resultados deste estudo podem ser explicados pelo aumento de infestação de doenças e pragas nas plantas, à medida que aumen tava sua idade.

E possîvel que a Figura 4 mostre, nas duas épo cas de semeadura, a mesma tendência das plantas a concentrarem sua produção em torno da metade do período das collheitas. Nas duas êpocas, poderia ter ocorrido o efeito inibidor, relatado por TIEDJENS (1928 a), da presença de frutos em desenvolvimento 
sobre a formação de novos frutos, provocando a queda de produçẫo apôs o primeìro pico atingzido; recuperando o equịiĺbrìo, a produção ter-se-ìa novamente elevado. As maiores produçốes tenderiam a concentrar-se na metade do período de colheitas.

A relativa uniformidade de comportamento da cul tivar Marketer, mostrada na Figura 5, confirma sua adaptabilidade, relatada por WHITAKER e DAVIS (1962). Talvez essa adap tabilidade se deva a uma menor sensibilidade dessa cultivar a variações ambientais, como sugerem os resultados obtidos por SHIFFRISS e GEORGE (1965).

Os resultados deste trabalho apresentam dois fa tores interessantes que podem ter aplicação prâtica. A correlação positiva significativa entre a produção total e a produ ção comerciâvel, jâ anteriormente relatada por RAMALHO (1973), sugere que seria possível avaliar a produção comerciável de cultivares de pepino por sua produção total. Do mesmo modo, os resultados obtidos em cada colheita, com exceção da prí meira, possivelmente poderiam ser utilizados para avaliar a produção total. 
6. CONCLUSÖES .

Para as condições deste experimento, concluiu-se que:

- a cultivar Aodai apresentou as maiores prodú ções e os frutos de melhor qualidade, enquanto Santee foi a me nos produtiva, com frutos de qualidade inferior aos das demais cultivares;

- Verde Paulistano e Aodai produziram frutos de maior peso médio;

- Verde Paulistano apresentou produção mais tar dia que as demais cultivares;

- relativamente às demais cultivares, Palomar e Verde Paulistano foram favorecidas pela semeadura em maio, e Ao dai, pela semeadura em dezembro;

- o comportamento de Marketer foi pouco afeta do pelas variaçôes ambientais; 
- para todas as cultivares, as produçôes de cạ da colheịta, com exceção das prìmeìras, foram representativas da produção tota1;

- as maiores produçôes de todas as cultivares foram obtidas entre a terceira e a penúltima colheitas;

- houve correlações positivas entre a produção tota1 e a produção comerciâvel, e entre o nủmero de frutos e seu peso;

- com o aumento da idade das plantas; diminui ram o peso mêdio dos frutos produzidos e a proporção de frutos comerciâveis;

- as plantas que apresentaram ramos principais mais longos e maior nümero de ramificaçôes laterais foram mais produtivas;

- as plantas obtidas por semeadura em maio apre sentaram maior produção e frutos de melhor qualidade que as obtidas por semeadura em dezembro. 
SUMMARY

The fresh fruit production of cucumber cultivars Marketer IAC-2205, Palomar IAC-3050, Santee IAC-2441, Verde Paulistano IAC-1386 and Aodai I-4321 was compared under two sowing dates, $5^{\text {th }}$ of May and $5^{\text {th }}$ of December of 1970 .

The plants were grown in field conditions in Cam pinas, SP, in a Yellow Red Latossol. The air temperature ran ged from $12,0^{\circ} \mathrm{C}$ to $26,8^{\circ} \mathrm{C}$ in the first period of culture, and from $18,5^{\circ} \mathrm{C}$ to $30,2^{\circ} \mathrm{C}$ in the second period.

Adequate cultural practices were provided. When the first female flower appeared in the field, inseticides and fungicides applications were interrupted.

For all cultivars, yields were higher and fruit quality was better in the first period of culture.

The plants have concentrated their highest yields between the third and the penultimate harvesting dates.

There were found positive correlations between yield in each harvesting date and total yield, total yield and 
- marketable yield, and number of fruits and their weight. The relation between marketable and total yields, and fruit avera ge weight, were negatively correlated with plant ages.

The plants sowed in May have presented a positi ve correlation between plantheight and yield, and between num ber of lateral branches and yield. For the plants sowed in December, these correlations were not significant.

In the first period of culture, there was inten se virus incidence affecting plants and, in the second period, the fruits were attacked by Margaronia sp. In both periods, it was observed some incidence of Pseudoperonospora cubensis in the plant leaves.

Both in May and December cultures, the Santee cultivar presented the lowest marketable and total yields, and the quality of its fruits was poor, in comparison with the other cultivars. Aodai showed the best performance as to fruit yield and fruit quality. The yields of the other cultivars we re similar. Verde Paulistano presented the Iatest fruit pro duction. Verde Paulistano and Aodai produced fruits with the highest average weight. Marketer showed a relatively uniform performance in both periods of culture. 
ABDEL-AL, Z.E., A.M. KHALF-ALLAH e G.S. SHENOUDA • 1973. Effect of visual selection and inbreeding on some quantitative characters of summer squash. Alexandria Journal of Agricul tural Research. Alexandria, 21: 277-282. Apud Plant Bre eding Abstracts. Cambridge, 45: 318, 1975. [ref. 4038].

ALEX, A.H. 1957. Honeybees aid pollination of cucumbers and cantaloupes. Gleanings in bee culture. Medina, 85: 398 -400 .

AMARAL, E., J. MITIDIERI e R. VENCOVSKY. 1963. Estudos sobre o comportamento da Apis melzifera L. na visita às flores do Cucumis sativus L. Ozericultura. Piracicaba, 3: 181-193.

ATSMON, D. 1968. The interaction of genetic, environmental, and hormonal factors in stem elongation and floral develop ment of cucumber plants. Annals of Botany. London, 32 : $877-882$. 
ATSMOND, D. e E. GALUN. 1962, Physịology of sex in Cucumis sa tivus L, Annals of Botany. London, 26: 127-146.

BARNES, W.C. e W.M. EPPS. 1956. Powdery mildew resistance in South Caroline cucumbers. Plant Disease Reporter. Was hington, $40: 1093$.

Boos, G.V. 1963. On the photoperiodic reaction of cucum bers. Trudy Prikladnoj Botanike, Genetike i Selekcii. Le ningrad, 35:94-97. Apud Horticultural Abstracts. East Ma1 1ing, 35:106, 1965. [ref. 964).

CAMPOS, H.R. e M.E.S. PAYAO 1969. Pepino sem pragas e doen ças. Guia Rural 1969/70. São Paulo, p. 122-124.

CARLSSON, G. 1962. Studies of factors affecting the yield and quality of cucumbers. I. Fruit lenght and fruit set ting. Acta Agriculturae Scandinavica. Stockholm, 12:355-362. Apud Plant Breeding Abstracts. Cambridge, 34:130, 1964. [ref. 1173].

CASTRO, L.A.B. de, V.C. de CARVALHO, F.A. COSTA e A.L. PEREIRA. 1953. Estudos preliminares sobre a utilização de híbridos trilineares e ginöicos de pepino (Cucumis sativus L.) do tipo de mesa. Arquivos da Universidade Federal do Rio de Janeiro. Rio de Janeiro, 3:61-66.

CASTRO, L.A.B. de, R.de L.D. RIBEIRO, A.L. PEREIRA, F. AKIBA, S. SUDO e L.B. BATISTA, 1972. Utilização de hïbridos $F_{1}$ de pepino (Cucumis sativus L.) do tipo de mesa. Agronomia. Rio de Janeiro, 30:4-15.

CASTRO, P.R.C. de, R.P.L. CARVALHO e M.E.S.P. DEMATTE. 1976. Diferenças na infestação de Margaronia sp. em cultivares de Cucumis sativus. Ciência e Cultura. Resumos. São Pau 1o, 28(7): 763. Suplemento. 
CHAMBliss, O.L. e C.M. JONES. 1966(a). Chemical and genetic ba sis for insect resistance in cucurbits. Proceedings of the American Society for Horticultural Science. Geneva, 89:394 -405 .

CHAMBLISS, O.L. e C.M. JONES. 1966(b). Cucurbitacins: specific attractans in Cucurbitaceae. Science. New York, 153:1392$-1393$.

CHAUDHARY, L.B. 1967. Correlation studies in Brassica juncea. Indian Journal of Genetics and Plant Breeding. New Delhi, $27: 289-292$.

CHAUVIN, R. 1968. Traité de Biologie de l'Abeizle. Paris, Masson. 4i tome: Biologie appliquée. $474 \mathrm{p}$.

COSTA, C.P. da e C.M. JONES. 1971. Resistance in cucumber, Cü cumis sativus L., to three species of cucumber beetles HortScience. St. Joseph, 6:340-342.

COUTO, F.A.A. 1959. Condições gerais para a escolha de um terreno para horta. In: COUTO, F.A.A. Olericultura Geral. Viçosa, U.F.R.M.G. p. 32-34.

DANIELSON, L.L. 1944. Effect of daylenght on growth and re production of cucumber. Plant Physiology. Bethesda, 19 : $638-648$.

DematTe, J.B.I., R. Inforzato, M.E.S.P. DEMATTE, T. igue e V. NAGAI. 1974. Influência da irrigação no desenvolvimento do sistema radicular do pepino. Circular do Instituto Agronô mico. Campinas, n. 38. 9 p.

DEMATTE, J.B.I., M.E.S.P. DEMATTE e V. NAGAI. 1974. Irrigação do pepino (Cucumis sativus L.) em solo argiloso. Circuzar do Instituto Agronômico. Campinas, n. $36.12 \mathrm{p}$. 
DEMATTE, M.E.S.P., L. de S. CAMARGO e T, IGUE: 1970. Efeito do tratamento da semente de pepino (Cucumis sativus L.) com di ferentes produtos desinfetantes; resumo. Revista de Oleri cultura. Viçosa, 10:65-67.

DEMATTE, M.E.S.P., L. de S. CAMARGO, T. IGUE e H.J. SCARANARI . 1970. Competição de variedades de pepino (Cucumis sativus L.); resumo. Revista de olericultura. Viçosa, 10:63-64.

DEMATTE, M.E.S.P., L. de S. CAMARGO, H. de F. LEITÁO FILHO, C. ARANHA, E. ABRAMIDES e V. NAGAI. 1970. Observação de va riedades de pepino. Revista de olericultura. Viçosa, 10: $69-70$.

DEMATTE, M.E.S.P., V. NAGAI e J.B.I. DEMATTE. 1975. Estudo de variedades e híbridos de pepino para salada. Boletim Técni co do Instituto Agronômico. Campinas, n. 29.28 p.

DORSET, H.J.M. van. 1975. Influence of temperature regime on virus diseases in cucumber. Acta Horticulturae. Tha Hague, (51): $329-332$.

EL-LAKANY, M.A. e W.A. RUSSELL, 1971. Relationship of maize characters with yield in testcrosses of inbreds at diffe rent plant densities. Crop Science. Madison, 11:698-701.

FILGUEIRA, F.A.R. 1972. Manual de Olericultura; cultura e co mercialização das hortaliças. São Paulo, Editora Agronô mica Ceres. $451 \mathrm{p}$.

FÖLSTER, E. $1974(\mathrm{a})$. The influence of air temperature on seedling development in greenhouse cucumbers]. Gemuse. Stuttgart, 10:5-7. Apud Horticultural Abstracts. East Malling, 44:504, 1974. (ref. 5651).

FOLSTER, E. $1974(\mathrm{~b})$. The influence of the root space temperature on the growth of young cucumbers. Acta Horticulturae. The Hague, (39): 153-159. 
FUKUSHIMA, E, E. MATSUO e K, FUJIEDA; 1968. Studies on the growth behaviour of cucumber, Cucumis sativus L. I. The types of sex expression and its sensitivity to various day lenght and temperature conditions. Journal of the Facul ty of Agriculture, Kyushu University. Fukuoka, 14:349-366 Apud Horticultural Abstracts. East Ma11ing, 39:92-93 1969. [ref. 710].

GALUN, E. 1961. Study of the influence of sex expression in the cucumber. The interaction of major genes with modi fying genetic and non genetic factors. Genetica. Gravenha ge, $32: 124-163$.

GOMES, G.P., A. BIANChETTI e L.M. de ARAUJO. 1974. Comporta mento de cultivares de pepino (Cucumis sativus L.) para consumo "in natura" na região de Morretes, PR; resumo. Re vista de Olericultura. Santa Maria, 14:93-94.

GREBENSCIKOV, I. 1963. QQuantitative genetic analysis of yield components in pumpkin): Kulturpflanze. Berlin, 11: 264-280. Apud Plant Breeding Abstracts. Cambridge, 34: 586, 1964. [ref. 4891].

GREBENSCIKOV, I. 1967. Quantitative genetic analysis of yield components in pumpkin. 3. Reciprocal crosses bet ween two widely differing types of C. maxima). Kulturpflan ze. Berlin, 15:57-74. Apud Plant Breeding Abstracts. Cam bridge, 39:204, 1969. (ref. 1159).

GUARDIA C., M.D. de 1a. 1970. Expressión de 1 sexo en el pe pino (Cucumis sativus L.) y su control por medios químicos Anales de Investigaciones Agronomicas. Madrid, 19: 113-134 .

HAYASE, H. 1961. Effect of temperature and humidity on the germination power of cucumber pollen after dehiscence. Jour nal of the Japanese Society of Horticultural Science. To kyo, 30:24-28. 
HAYNES, R.L. e C.M, JONES, 1975. Wilting and damage to cucum ber by spotted and striped cucumber beetles. Hortscience. St.Joseph, 10:265-266.

HOFFMANN, R. e S. VIEIRA. 1977. Análise de Regressão. São Paulo, Editora da USP. 339p.

JOHNSON, H.W., H.F. ROBINSON e R.E. COMSTOCK. 1955. Genoty pic correlation in soybeans and their implication in se lection. Agronomy Journal. Washington, 47:477-483.

KNOTT, J.E. 1966. Hondbook for Vegetable Growers. New York, John Wiley. $245 \mathrm{p}$.

LAVALLEE, E. 1967. Observations sur 1a rësistance à la gale Cladosporium cucumerinum E11. et Art. de quelques varietës de concombre de table. phytoprotection. Montreal, $48:$ 1-3 .

MAKISHIMA, N. 1973. Desenvolvimento e importância da oleri cultura no Brasil. Revista de Olericultura. Brasilia, 13:139-140.

MATLOB, A.N. e W.C. KELLY. 1973. The effect of high temperature on pollen growth of snake cucumber and cucumber. Joup nal of Amexican Society for Horticultural Science. Gene va, $98: 296-300$.

MELFI, A.J., V.A.V. GIRARDI e A.C. MONIZ. 1966. Mineralogia dos solos da Estação Experimental "Theodureto de Camargo", em Campinas. Bragantia. Campinas, 25:9-30.

MILLER, J.C. e J.E. QUISENBERRY. 1976. Inheritance of time to flowering and its relationship to crop maturity in cu cumber. Journal of the American Society for Horticultural Science. Geneva, 101:497-500. 
MILTHORPE, F.L., 1959. Studies on the expansion of the leaf surface. I. The influence of temperature. Journal of $E \underline{x}$ perimental Botany: Oxford, 10:233-249.

MILTHORPE, F.L. e P. NEWTON. 1963. Studies on the expansion of the leaf surface. III. The influence of radiation on ce11 division and leaf expansion. Journal of Experimental Botany. Oxford, 14:483-495.

MITAL, S.P., V. SWARUP, M.M. KOHLI e H.B. SINGH. 1969. Varia bility in guar. Indian Journal of Genetics and plant Breeding. New Delhi, 29:98-103.

MITAL, S.P. e THOMAS, T.A. 1969. Correlation and selection indices in improvement of seed yield in guar. Indian Jour nal of Genetics and Plant Breeding. New Delhi, 29:10-17.

MITIDIERI, J., E.C. FERRAZ e R. VENCOVSKY, 1963. Ap1icação de hormônios em Cucumis sativus L. visando o aumento do núme ro de flores femininas. OZericultura. Piracicaba, 3:145-150 .

MOLL, R.H. e C.W. STUBER, 1971. Comparisons of responses to alternative selection procedures initiated with two popula tions of maize (Zea mays L.). Crop Science. Madison, 11: $706-711$.

MURILLO A., G., R. GUARDIAN. G. e W.J. WILTBANK. 1963. Prueba de rendimiento con variedades de pepinos (Cucumis sativus). Boletin Técnico del Ministerio de Agricultura y Ganaderia, Costa Rica. San Josê, n.41. 8 p.

NEWTON, P., 1963. Studies on the expansion of the leaf surfa ce. II. The influence of light intensity and daylenght. Journal of Experimental Botany. Oxford, 14:458-482. 
NIGMANOVA, N.N.. 1963. (Comparing morphological character and yield in certain forms of cucurbits] Uzbekskü Biologiches kü Zhurnal. Tashkent; (3): 57-61. Apud Plant Breeding Abstracts. Cambridge, 36:366, 1966. (ref. 2821).

NILSSON, C. 1968. Temperature and germination in Cucumis sa tivus L. Agri Hortique Genetica. Landskrona, 25:161-68. Apud Horticultural Abstracts. East Malling, 38:977, 1968. [ref. 7649].

NITSH, J.P., E.B. KURTZ, J.L. LIVERMAN e F.W. WENT, 1952. The development of sex expression in cucurbit flowers. Ameri can Journal of Botany. Lancaster, 39:32-42.

NUTTALL, V.W. e G.G. JASMIN. 1958. The inheritance of resistan ce to bacterial wilt (Erwinia tracheiphila. (E.F. Sm.) Holland) in cucumber. Canadian Journal of Plant Science. Ot tawa, $38: 401-404$.

PARR, W.J. e N.W. HUSSEY, 1962. Response of cucumber plant to different levels of artificial leaf damage in on at tempt to simulate the effects of red spider mite. Report of the Glasshouse Crops Research Institute. Littlehampton, p. 95-99. Apud Horticultural Abstracts. East Maliing, $33: 92$, 1963. [ref. 852).

PAVATE, M.V. e G.S. MURTY, 1963. Adequacy of linear model in discriminatory analysis for plant selection. Indian Jour nal of Genetics and Plant Breeding. New Delhi, 23:331-336.

PIMENTEL GOMES, F. 1963. Curso de Estatistica Experimental. 2. ed. Piracicaba, ESALQ/USP. $384 \mathrm{p}$.

PlOEGMAN, C. e J.F. BIERHUIZEN. 1970. (Salt tolerance in cucum ber]. Bedrijfsontwikkeling, Editie Tuinbouw. Wageningen, 1:32-39. Apud Horticultural Abstracts. East Malling., 41-140, 1971. [ref. 1105]: 
PORTHSMOUTH, G, 1937. The effect of a1ternate periods of light and darkness of short duration on growth of the cu cumber. Annals of Botany. London, 1:175-189.

RAMALHO, M.A.P. 1973. Hábito de Florescimento e Frutifica ção do Pepino (Cucumis sativus L.). Piracicaba, ESALQ / /USP, 48 p. (Dissertação de Mestrado).

RIBBANDS, C.R. 1953. The Behaviour and Social Life of Honey bees. London, Bee Research Association. $352 \mathrm{p}$.

SACHAN, C.P. e S.B.B. TIKKA: 1971. Genetic variability and correlation studies in watermelon (Citrullus lanatus

Thunb. Mansf.). Rajasthan Journal of Agricultural Scien ce. Udaipur, 2:91-96. Apud Plant Breeding Abstracts. Cam bridge, 46:406, 1976. (ref. 4801).

SAITO, T. 1961. Factors responsible for the sex expression of Japanense cucumber. X. Studies on the dark process. Journal of the Japanese society of Horticultural Science. Tokyo, 30:1-8.

SCHULTE, H.K. e U.GROTE, 1974. (Studies on the cold hardiness of outdoor cucumbers]. Gartenbauwissenschaft. Berlin, 39: 241-251. Apud Horticultural Abstracts. East Malling, 45: 840, 1975. [ref. 9538].

SEATON, H.L. e J.C. KREMER, 1938. The influence of climatological factors on anthesis and anther dehiscence in the cultivated cucurbits. A preliminary report. Proceedings of the American Society for Horticultural Science. Gene va, $36: 627-631$.

SEGET'A, V. 1966(a). TThe ecology and physiology of the cold resistance of cucumbers during emergence. I. The effect of temperature and properties of the soil substrate on the emergence of cucumbers]. Rostlină vóroba. Praha, 12 :

317-334. Apud Horticultural Abstracts. East Ma11ing, 37 : 112, 1967. [ref. 849]. 
SEGET'A. V. 1966 (b). The ecology and physiology of the cold resistance of cucumbers during emergence. II. The physio logical reaction of cucumber seeds and seedlings to the effects of low temperatures]. Rostliná Víroba. Praha, 12 : 317-344. Apud Horticultural Abstracts. East Malling, 37: 112, 1967. (ref. 849).

SEGET'A. V. e E. TRONICKROVA. 1966. (The ecology and physiolo gy of the cold resistance of cucumbers during emergence. II. The variability of cold resistance in cucumber seed samples of different varieties, age and source under 1 abo ratory and natural conditions). Rostlină Víroba. Praha, 12:1113-1126. Apud Horticultural Abstracts. East Ma11ing $37: 577,1967$. (ref. 4848).

SHARMA, G.C. e C.V. HALL, 1971. Influence of cucurbitacins, sugars, and fatty acids on cucurbit susceptibility to spot ted cucumber beetle. Journal of the American Society for Horticultural Science. Geneva, 96:675-680.

SHIFFRISS, 0. e E. GALUN. 1956. Sex expression in the cucum ber. Proceedings of the American Society for Horticultu ral Science. Geneva, 67:479-489.

SHIFFRISS, O. e W.L. GEORGE Jr. 1965. Delayed germination and flowering in cucumbers. Nature. New York, 206:424-425 .

SHIH, C.Y., 1947. [Correlation between vegetative characters and yield of soya bean]. Northwestern Agriculturist. Min neapolis, 2:23-25. Apud Plant Breeding Abstracts. Cam bridge, 18:172, 1948. [ref. 573].

SIKKA, S.M. e N.D. GUPTA. 1949. Correlation studies in sesa num orientable L. Indian Journal of Genetics and Plant Breeding. New Delhi, 9:27-32. 
SINGH, H.N., R.R, SINGH e R.K. MITAL, 1974. Genotypic and phenotypic variability in tomato. Indian Journal of Gene tics and Plant Breeding. New Delhi, 44:807-811.

SINGH, K.B. e P.D, MEHNDIRATTA, 1969. Genetic variability and correlation studies in cowpea. Indian Journal of Genetics and PZant Breeding. New Delhi, 29:104-109.

SRIVASTAVA, J.P., H.N. SINGH e S.P. SINGH. 1972. Genetic stu dies on yield componentes in pea (Pisum sativum L.). In dian Journal of Agricultural Science. New De1hi, 42:1001-1004 .

STENE, J. 1964. (Pruning of cucumbers). Garteryrket. 54 : 348-349. Apud Horticultural Abstracts. East Malling, 34: 489,1964 . [ref, 4697].

SULLIVAN, M.J. e C.H. BRETT, 1971. Resistance of cucurbit va rieties to the spotted cucumber beetle in the coastal plain of North Carolina. Journal of Economic Entomology. Gene va, 64: 1205-1208.

SWAMY RAO, T., A. RAMAMURTHY, S.J. PATIL, R.S. ARADHYA e N.B. KAJJARI, 1970. Evaluation of maize introductions in Mysore State. 1. Adaptation and genotypic variability in four environments. Genetica Agraria. Roma, 24:303-315.

TATSUMI, M. e Y. HORI, 1970. (Studies on photosynthes is in ve getable crops. II. Effect of temperature on the photosyn thesis of young vegetable plants in relation to light in tensity]. Bulletin of the Horticultural Research Station, Hiratsuka, (9): 181-188. Apud Horticultural Abstracts. East Ma11ing, 42:766, 1971. [ref. 6350].

TERRA, G.J.A. 1966. Tropical Vegetables; vegetable growing in the tropics and subtropics specially of indigenous ve getables. Amsterdam, Department of Agricultural Research. 107p. (Communication n. $54 \mathrm{e}$ ). 
THAMBURAJ, S. 1973. Correlation studies in ribbed gourd ( $L u f$ fa acutangula L.). Madras Agricultural Journal. Madras, 60:61. Apud Plant Breeding Abstracts, Cambridge, 43 : 824,1973 . [ref. 10104].

TIEDJENS, V.A. 1928 (a). Sex ratios in cucumber flowers as affected by different conditions of soil and light. Jour nal of Agricultural Research. Washington, 36:731-736.

TIEDJENS, V.A. 1928(b). The relation of environment to sha pe of fruit in Cucumis sativus L and its bearing on the genetic plants. Journal of Agricultural Research. Washing ton, $36: 795: 809$.

WHITAKER, T.W. e G.N. DAVIS, 1962. Cucurbits; botany, culti vation, and utilization. London, Leonard Hi11. 250 p.

WHITEHEAD, S.B., 1954. Bees to the Heather. London, Faber and Faber. $96 \mathrm{p}$. 